\title{
PENDUGAAN PARAMETER GENETIK DAN SELEKSI \\ POPULASI SORGUM (Sorghum bicolor (L.) Moench) \\ HASIL PENGGALURAN DENGAN METODE \\ SINGLE SEED DESCENT
}

RANGGI RAHIMUL INSAN

${ }^{T}$

恋

PEP

尽

$\mathrm{OGO}^{\circ}$

SEKOLAH PASCASARJANA INSTITUT PERTANIAN BOGOR BOGOR

2016 



\section{PERNYATAAN MENGENAI TESIS DAN SUMBER INFORMASI SERTA PELIMPAHAN HAK CIPTA*}

Dengan ini saya menyatakan bahwa tesis berjudul Pendugaan Parameter Genetik dan Seleksi Populasi Sorgum (Sorghum bicolor (L.) Moench) Hasil Penggaluran dengan Metode Single Seed Descent adalah benar karya saya dengan arahan dari komisi pembimbing dan belum diajukan dalam bentuk apa pun kepada perguruan tinggi mana pun. Sumber informasi yang berasal atau dikutip dari karya yang diterbitkan maupun tidak diterbitkan dari penulis lain telah disebutkan dalam teks dan dicantumkan dalam Daftar Pustaka di bagian akhir tesis ini.

Dengan ini saya melimpahkan hak cipta dari karya tulis saya kepada Institut Pertanian Bogor.

Bogor, Februari 2016 



\section{RINGKASAN}

RANGGI RAHIMUL INSAN. Pendugaan Parameter Genetik dan Seleksi Populasi Sorgum (Sorghum bicolor (L.) Moench) Hasil Penggaluran dengan Metode Single Seed Descent. Dibimbing oleh DESTA WIRNAS dan TRIKOESOEMANINGTYAS.

Sorgum (Sorghum bicolor (L.) Moench) merupakan tanaman serealia yang dapat dimanfaatkan sebagai sumber pangan, pakan, dan bioetanol. Sorgum mempunyai potensi besar untuk dijadikan tanaman pangan di Indonesia karena tanaman ini toleran terhadap kekeringan dan genangan air, dapat berproduksi pada lahan marginal, serta relatif tahan terhadap gangguan hama dan penyakit. Produktivitas sorgum di Indonesia masih rendah. Hal ini disebabkan karena varietas unggul di Indonesia masih terbatas.

Varietas unggul sorgum nasional yang ada saat ini dikembangkan melalui teknik mutasi dan introduksi, sedangkan melalui teknik persilangan belum banyak dilakukan. Upaya peningkatan produktivitas sorgum di Indonesia harus didukung oleh ketersediaan varietas unggul sorgum yang adaptif dan berdaya hasil tinggi di Indonesia. Perakitan varietas sorgum berdaya hasil tinggi melalui persilangan telah dilakukan sehingga diperoleh galur-galur sorgum yang siap diuji daya hasil dan kemampuan adaptasinya di Indonesia.

Tujuan penelitian ini adalah: (1) mendapatkan informasi tentang keragaman pada populasi F4 dan F5 yang diperoleh melalui metode penggaluran single seed descent hasil persilangan antara B69 dengan Numbu, (2) mendapatkan informasi tentang keeratan hubungan antara karakter agronomi dengan daya hasil, (3) melakukan seleksi galur harapan sorgum berdasarkan daya hasil serta memiliki keseragaman yang rendah dalam galurnya terutama pada karakter tinggi tanaman dan bobot biji malai ${ }^{-1}$.

Penelitian terdiri dari dua percobaan, yaitu (1) analisis keragaman populasi F4 hasil single seed descent dari persilangan B69 dan Numbu, (2) pendugaan nilai parameter genetik dan seleksi galur-galur inbreed F5. Percobaan pertama dilaksanakan di Kebun Percobaan Leuwikopo, Dramaga, Bogor dengan ketinggian $240 \mathrm{~m}$ dpl dan suhu rata-rata $25.8{ }^{\circ} \mathrm{C}$ pada bulan Februari sampai Mai 2014. Materi genetik yang digunakan adalah populasi F4 dan 2 varietas kontrol berupa B69 dan Numbu. Percobaan kedua dilakukan pada bulan Juli sampai Oktober 2014 di Dramaga, Bogor dengan suhu rata-rata $27.4{ }^{0} \mathrm{C}$. Rancangan percobaan yang digunakan adalah rancangan augmented design. Materi genetik yang digunakan adalah 201 RILs F5 hasil persilangan B69 x Numbu dan 4 varietas kontrol yaitu Numbu, Samurai-1, Samurai-2, dan galur mutan B69.

Hasil penelitian pertama menunjukkan nilai tengah populasi F4 pada karakter tinggi tanaman, jumlah daun, panjang malai, lingkar malai, bobot malai, bobot seribu biji, dan bobot biji malai ${ }^{-1}$ berada di antara nilai tengah kedua tetua, sementara karakter diameter batang memiliki nilai tengah lebih tinggi dari kedua tetua. Seluruh karakter agronomi memiliki sebaran normal, bersifat poligenik dan dipengaruhi oleh aksi gen aditif. Heritabilitas yang tinggi dan keragaman genetik yang luas terdapat pada diameter batang, bobot malai, dan bobot biji malai ${ }^{-1}$. Metode single seed descent dapat mempertahankan nilai heritabilitas yang tinggi dan keragaman genetik yang luas sampai generasi F4. 
Hasil analisis ragam pada penelitian kedua menunjukan bahwa RILs F5 yang diuji berbeda nyata pada karakter periode pengisian biji, tinggi tanaman, jumlah daun, panjang malai, lingkar malai, bobot malai, dan bobot biji malai ${ }^{-1}$. Disamping itu pada populasi RILs F5 menunjukan bahwa galur-galur yang diuji memperlihatkan keragaman genetik yang luas dan heritabilitas tinggi pada karakter periode pengisian biji, tinggi, tanaman, jumlah daun, panjang malai, lingkar malai, bobot malai, dan bobot biji malai ${ }^{-1}$. Terdapat RIL F5 yang memiliki ragam dalam galur lebih rendah dan memiliki daya hasil lebih baik dibanding kedua tetua. Seleksi berdasarkan bobot biji malai ${ }^{-1}$ meningkatkan hasil $35.3 \%$ namun tinggi tanaman meningkat 5\%. Seleksi berdasarkan bobot biji malai $^{-1}$ dan tinggi tanaman meningkatkan hasil $21 \%$ dan mengurangi tinggi tanaman $6,9 \%$. Hal ini memberikan kesempatan untuk mendapatkan varietas unggul dengan tinggi tanaman yang lebih pendek. Galur-galur RIL terpilih dapat dilanjutkan untuk pengujian daya hasil pendahuluan.

Kata kunci: Sorgum, analisis korelasi, sidik lintas, augmented, heritabiltas, seleksi satu karakter dan seleksi dua karakter 


\section{SUMMARY}

RANGGI RAHIMUL INSAN. Estimation of Genetic Parameters and Selection of Sorghum (Sorghum bicolor (L.) Moench) Derived from Single Seed Descent Method. Surprised by DESTA WIRNAS and TRIKOESOEMANINGTYAS.

Sorghum (Sorghum bicolor (L.) Moench) is a cereal crop that can be used as a source of food, feed and bioethanol. Sorghum is a crop alternatives that can be planted in marginal land of Indonesia because sorghum has wide adaptability. Sorghum productivity in Indonesia is still low. This is because sorghum varieties in Indonesia is still limited.

National sorghum varieties available today are introduced varieties or varieties developed through mutation techniques. Development sorghum varieties through crossing is still need.

The purpose of this study is (1) to obtain information on variation of population F4 and F5 obtained through single seed descent method of F1 from hybridization between B69 and Numbu, (2) to obtain information on the correlation between agronomic characters with yield, (3) to select promising lines with a high yield.

The study consisted of two experiments, namely (1) analysis of variability of F4 single seed descent result of crossing B69 and Numbu and (2) estimation of genetic parameters and selection inbreed lines F5. The First experiment was conducted at the Experimental Farm Leuwikopo, Dramaga, Bogor with a height of $240 \mathrm{~m}$ above sea level and an average temperature of $25.8^{\circ} \mathrm{C}$ from February to Mai 2014. The genetic material used was F4 population and B69 and Numbu as check control. The second experiment was conducted in July until October 2014 in Dramaga, Bogor with an average temperature of $27.4{ }^{\circ} \mathrm{C}$. The experimental design used is an augmented design. Genetic material used is 201 RILs F5 of B69 $\mathrm{x}$ Numbu and four genotypes as control Numbu, Samurai-1, Samurai-2, and B69.

All traits observed have normal distribution. It is mean that the traits are polygenic and controlled by additive gene action. Diameter stem , panicle weight, grain weight per panicle show a high Heritability and wide genetic variation. The experiment show that single seed descent method can maintain the high heritability and wide genetic variation to F4.

The results showed that the RILs F5 significantly different in the characters of seed filling period, plant height, leaf number, panicle length, circumference panicle, panicle weight, and grain weight panicle ${ }^{-1}$. High broad sense heritability values and broad genetic diversity were observed in the character of the seed filling period, plant height, leaf number, panicle length, circumference panicle, panicle weight and grain weight panicle ${ }^{-1}$. There were RILs F5 which have higher yield than the two parents and are uniform with lower within line variance. Selection was conducted based on grain weight panicle ${ }^{-1}$ increased $35.3 \%$ yield, but at the same time increased plant height by $5 \%$. Simultaneous selection by grain weight per panicle and plant height increased yield by $21 \%$ and reduced plant height by $-6.9 \%$. This gives the opportunity to obtain shorter high yielding varieties. Selected Recombinant inbreed lines can be continued to yield preliminary testing.

Keywords: Sorghum, correlation analysis, cross examination, augmented, heritability, selection of the one characters and the selection of two characters. 


\section{(C) Hak Cipta Milik IPB, Tahun 2016 Hak Cipta Dilindungi Undang-Undang}

Dilarang mengutip sebagian atau seluruh karya tulis ini tanpa mencantumkan atau menyebutkan sumbernya. Pengutipan hanya untuk kepentingan pendidikan, penelitian, penulisan karya ilmiah, penyusunan laporan, penulisan kritik, atau tinjauan suatu masalah; dan pengutipan tersebut tidak merugikan kepentingan $I P B$

Dilarang mengumumkan dan memperbanyak sebagian atau seluruh karya tulis ini dalam bentuk apa pun tanpa izin IPB 


\section{PENDUGAAN PARAMETER GENETIK DAN SELEKSI \\ POPULASI SORGUM (Sorghum bicolor (L.) Moench) \\ HASIL PENGGALURAN DENGAN METODE \\ SINGLE SEED DESCENT}

\section{RANGGI RAHIMUL INSAN}

Tesis

sebagai salah satu syarat untuk memperoleh gelar

Magister Sains

pada

Program Studi Pemuliaan dan Biotekhnologi Tanaman

SEKOLAH PASCASARJANA

INSTITUT PERTANIAN BOGOR

BOGOR

2016 
Penguji Luar Komisi pada Ujian Tesis: Prof Dr Ir Didy Sopandie, MAgr 


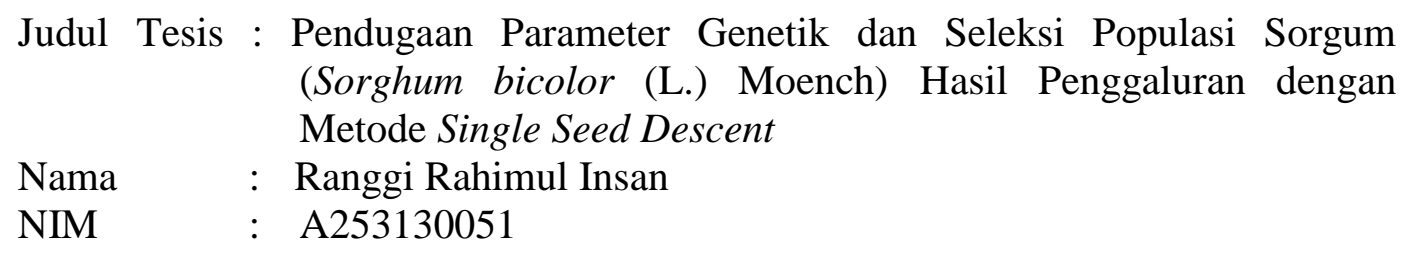

Disetujui oleh

Komisi Pembimbing

Dr Desta Wirnas, SP MSi

Ketua $\underline{\text { Dr Ir Trikoesoemaningtyas, MSc }}$

Anggota

\section{Diketahui oleh}

Ketua Program Studi

Pemuliaan dan Bioteknologi Tanaman
Dekan Sekolah Pascasarjana

$\underline{\text { Dr Ir Yudiwanti Wahyu EK, MS }}$

$\underline{\text { Dr Ir Dahrul Syah, MScAgr }}$ 



\section{PRAKATA}

Puji syukur penulis panjatkan ke hadirat Allah SWT atas rahmat dan hidayah-Nya sehingga penulis dapat menyelesaikan penulisan Tesis ini. Judul penelitian yang dipilih adalah Pendugaan Parameter Genetik dan Seleksi Populasi Sorgum Hasil Penggaluran dengan Metode Single Seed Descent. Tesis ini merupakan salah satu syarat untuk mendapatkan gelar Magister Sains di Program Studi Pemuliaan dan Bioteknologi Tanaman, Sekolah Pascasarjana, Institut Pertanian Bogor.

Pengembangan galur-galur sorgum yang memiliki daya hasil tinggi merupakan salah satu usaha pemerintah dalam meningkatkan produksi sorgum nasional. Pengembangan galur sorgum menggunakan metode penggaluran single seed descent adalah satu cara dalam merakit varietas unggul sorgum berdaya hasil tinggi.

Penulis mengucapkan terima kasih kepada Dr Desta Wirnas, SP MSi dan Dr Ir Trikoesoemaningtyas, MSc sebagai komisi pembimbing, Prof Dr Ir Didy Sopandie, MAgr sebagai dosen penguji luar komisi ujian tesis serta kepada Dr Ir Yudiwanti Wahyu Endro Kusumo, MS sebagai Ketua Program Studi yang telah memberikan saran dan motivasi dalam pelaksanaan penelitian dan penulisan Tesis ini. Penulis juga menyampaikan terima kasih atas pembiayaan penelitian dalam tesis ini melalui skema penelitian unggulan perguruan tinggi tahun 2014 serta Beasiswa Pendidikan Pascasarjana Dalam Negeri (BPPDN) Tahun 2013. Ungkapan terima kasih penulis sampaikan kepada kedua orangtua Drs Jon Adri dan Dra Ermawati Arief, MPd, kepada saudaraku Girang Rahmanul Hakim, teman-teman Pemuliaan dan Bioteknologi Tanaman (PBT) angkatan 2013, dan teman-teman di Laboratorium Pemuliaan Tanaman atas bantuan dan dukungan yang diberikan. Semoga tulisan dan penelitian ini dapat memberi manfaat bagi dunia Pertanian dan pihak lain yang membutuhkannya.

Bogor, Februari 2016 



\section{DAFTAR ISI}

DAFTAR TABEL vii

DAFTAR GAMBAR viii

DAFTAR LAMPIRAN viii

1 PENDAHULUAN

Latar Belakang $\quad 1$

Tujuan Penelitian $\quad 2$

2 TINJAUAN PUSTAKA 4

Klasifikasi dan morfologi Sorgum $\quad 4$

Metode Penggaluran Single Seed Descent 6

Parameter Genetik dan Seleksi $\quad 7$

3 KERAGAAN DAN KERAGAMAN POPULASI F4 SORGUM HASIL PENGGALURAN DENGAN METODE SINGLE SEED DESCENT

Abstract $\quad 12$

$\begin{array}{ll}\text { Abstrak } & 12\end{array}$

$\begin{array}{ll}\text { Pendahuluan } & 13\end{array}$

Metode Penelitian 14

Hasil dan Pembahasan 16

$\begin{array}{ll}\text { Simpulan } & 28\end{array}$

4 PENDUGAAN PARAMETER GENETIK DAN SELEKSI RILS F5 SORGUM HASIL PENGGALURAN DENGAN METODE SINGLE SEED DESCENT

Abstract $\quad 29$

Abstrak $\quad 29$

$\begin{array}{ll}\text { Pendahuluan } & 30\end{array}$

Metode Penelitian $\quad 31$

Hasil dan Pembahasan $\quad 34$

Simpulan $\quad 53$

5 PEMBAHASAN UMUM 54

6 SIMPULAN DAN SARAN 58

Simpulan $\quad 58$

$\begin{array}{ll}\text { Saran } & 58\end{array}$

DAFTAR PUSTAKA

$\begin{array}{ll}\text { LAMPIRAN } & 66\end{array}$

$\begin{array}{ll}\text { DAFTAR RIWAYAT HIDUP } & 69\end{array}$ 


\section{DAFTAR TABEL}

1 Metode penggaluran pada tanaman menyerbuk sendiri 6

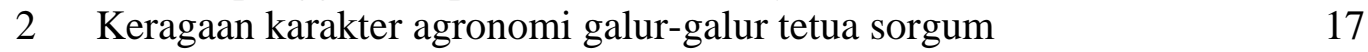

3 Keragaan karakter agronomi tetua dan populasi F4 sorgum hasil 18 persilangan B69 x Numbu

4 Aksi gen karakter agronomi populasi F4 (B69 x Numbu) sorgum. 25

5 Jumlah gen karakter agronomi populasi F4 (B69 x Numbu) sorgum 25

6 Nilai komponen ragam dan koefisien keragaman genetik (KKG) 26 karakter agronomi pada populasi F4 sorgum

7 Koefisien korelasi karakter agronomi populasi F4 hasil persilangan 27 B69 x Numbu sorgum

8 Analisis ragam rancangan augmented RKLT 32

9 Kuadrat tengah RILs F5 (B69 x Numbu) dan varietas kontrol terhadap 34 karakter agronomi sorgum

10 Keragaan varietas kontrol sorgum 35

11 Keragaan populasi RILs F5 sorgum hasil persilangan B69 x Numbu 36

12 Pendugaan parameter genetik karakter agronomi RILs F5 sorgum 38

13 Koefisien korelasi antar karakter agronomi pada populasi RILs F5 43 sorgum hasil persilangan B69 x Numbu

14 Pengaruh langsung dan tidak langsung karakter agronomi terhadap 44 bobot biji malai ${ }^{-1}$ pada populasi RILs F5 sorgum hasil persilangan B69 $\mathrm{x}$ Numbu

15 Nilai tengah, ragam dalam galur, dan ragam antar galur 201 RIL F5 46 sorgum

16 Diferensial seleksi berdasarkan bobot biji malai ${ }^{-1}$ sorgum 47

17 Diferensial seleksi berdasarkan bobot biji malai ${ }^{-1}$ dan tinggi tanaman 48 sorgum

18 Keragaan fenotipik karakter agronomi RILs F5 sorgum (B69 x 49 Numbu) hasil seleksi berdasarkan bobot biji malai ${ }^{-1}$ dan tinggi tanaman 


\section{DAFTAR GAMBAR}

$1 \quad$ Alur kegiatan penelitian 3

2 Fase pertumbuhan tanaman sorgum 16

3 Sebaran karakter diameter batang populasi F4 sorgum 18

4 Sebaran karakter tinggi tanaman populasi F4 sorgum 19

5 Sebaran karakter jumlah daun populasi F4 sorgum 20

6 Sebaran karakter panjang malai populasi F4 sorgum 21

7 Sebaran karakter lingkar malai populasi F4 sorgum 21

8 Sebaran karakter bobot malai populasi F4 sorgum 22

9 Sebaran karakter bobot seribu biji populasi F4 sorgum 23

10 Sebaran karakter bobot biji malai ${ }^{-1}$ populasi F4 sorgum 23

11 Keragaman malai sorgum pada varietas control 39

12 Keragaman malai sorgum pada populasi RILs F5 39

13 Diagram lintasan karakter agronomi terhadap bobot biji malai ${ }^{-1} \quad 45$ RILs F5 sorgum (B69 x Numbu)

\section{DAFTAR LAMPIRAN}

$1 \quad$ Deskripsi varietas sorgum 66

2 Rata-rata curah hujan dan temperatur selama penelitian di Dramaga 67

3 Algoritma eksplorasi kecenderungan sebaran sifat-sifat kuantitatif 68 kaitannya dengan aksi gen aditif, dominan serta epistasis komplementer dan duplikat. 


\section{PENDAHULUAN}

\section{Latar Belakang}

Sorgum merupakan salah satu tanaman serealia yang mempunyai potensi besar untuk dikembangkan. Potensi besar disebabkan karena sorgum mampu tumbuh di dataran rendah hingga dataran tinggi mencapai $1500 \mathrm{~m} \mathrm{dpl}$, dapat ditanam di daerah tropis atau subtropis, dan memiliki toleransi terhadap iklim yang berubah ubah (Hoeman 2007). Menurut Acquaah (2007) sorgum dapat dimanfaatkan sebagai bahan pangan, pakan, dan bioetanol. Biji sorgum dimanfaatkan sebagai sumber pangan dalam bentuk beras dan tepung (Beti et al. 1990). Biji dan batang sorgum dapat dimanfaatkan sebagai bahan baku etanol (Pabendon et al. 2012). Batang dan daun sogrum digunakan sebagai hijauan pakan ternak (Purnomohadi 2006).

Produksi sorgum dunia pada tahun 2012 telah mencapai 58 juta ton. Total produksi sorgum dunia berasal dari negara-negara di Afrika sebesar 40.34\%, Amerika sebesar 38.11\%, Asia 16.36\%, Ocenia 3.86\%, dan Eropa sebesar $1.34 \%$ (FAOSTAT 2013). Menurut Taylor (2002) negara di Afrika penghasil sorgum terbesar adalah Nigeria, Sudan, Ethiopia, dan Burkina Faso.

Produksi sorgum di Indonesia masih rendah. Menurut Ditjen Tanaman Pangan (2013) produktivitas sorgum pada tahun 2011 hanya 2.1 ton $\mathrm{ha}^{-1}$. Beberapa faktor penyebabnya adalah; terbatasnya luas tanam dan jumlah varietas unggul serta usaha tani sorgum di tingkat petani yang belum intensif. Disamping itu perkembangan produksi sorgum nasional belum masuk dalam statistik pertanian yang menunjukkan komoditas ini belum mendapat prioritas untuk dikembangkan (Sirappa 2003). Perlu pemahaman dalam bidang pemuliaan tanaman mengenai peningkatan keragaman genetik sebagai langkah awal dalam merakit varietas unggul nasional baru yang berdaya hasil tinggi.

Usaha meningkatkan keragaman genetik dalam rangka menghasilkan varietas unggul sorgum di Indonesia secara umum dihasilkan melalui teknik mutasi dan introduksi, sedangkan melalui teknik persilangan belum banyak dilakukan. Departemen Agronomi dan Hortikultura, Fakultas Pertanian, Institut Pertanian Bogor telah melakukan persilangan B69 x Numbu pada tahun 2010 dan menghasilkan populasi F3 melalui metode penggaluran single seed descent. Studi keragaan dan keragaman dilanjutkan hingga populasi F4 kemudian dilanjutkan dengan seleksi populasi F5 untuk mendapatkan galur-galur berdaya hasil tinggi.

Berdasarkan penelitian sebelumnya yang dilakukan oleh Rini (2014) diketahui bahwa dari berbagai evaluasi persilangan yang dilakukan, generasi F1 hasil persilangan B69 x Numbu merupakan kombinasi persilangan terbaik untuk karakter hasil. Hal ini disebabkan karena kedua tetua memiliki daya gabung khusus yang tinggi serta nilai heterosis yang lebih tinggi dbandingkan generasi F1 hasil persilangan lainnya. Generasi F2 hasil persilangan Numbu x B69 yang dilakukan Sulistyowati (2015) menunjukan bahwa seluruh karakter hasil yang diamati memiliki sebaran normal, bersifat poligenik dengan aksi gen aditif sehingga seleksi akan efektif dilakukan pada generasi lanjut pada saat fiksasi gen aditifnya sudah semakin baik. Berdasarkan hal tersebut maka terdapat potensi yang diinginkan pemulia untuk menghasilkan varietas unggul sorgum berdaya hasil tinggi melalui persilangan B69 x Numbu pada generasi lanjut. 
Metode single seed descent merupakan salah satu metode penggaluran pada tanaman menyerbuk sendiri. Metode single seed descent dirancang untuk mengembangkan galur murni superior dan telah berhasil digunakan pada tanaman sereal, kedelai, tomat, dan selada. Seleksi pada metode single seed descent dilakukan di generasi lanjut (F5/F6) pada saat proporsi homozigositas sudah tinggi (Chahal \& Gosal 2003). Keunggulan metode single seed descent adalah dapat mempertahankan keragaman genetik yang luas seperti generasi awal dan dapat menghasilkan sejumlah galur yang superior untuk hasil biji tanaman ${ }^{-1}$ pada generasi lanjut. Hal ini disebabkan karena peran seleksi alam sehingga genotipe yang tumbuh merupakan genotipe unggul yang mampu beradaptasi terhadap lingkungan (Ibrahim 2015; Roy 2000).

Nilai parameter genetik merupakan informasi dasar yang penting bagi efektivitas seleksi dalam rangka perbaikan karakter tanaman. Keberhasilan pemuliaan tanaman sangat bergantung pada efektivitas seleksi yang ditentukan oleh tingkat keragaman genetik dan derajat pewarisan karakter yang diukur melalui nilai heritabilitas (Singh \& Chaudhary 1979). Nilai heritabilitas diperlukan untuk mengetahui kemampuan tetua dalam menurunkan sifat-sifat unggul pada turunannya dan menduga kemajuan genetik akibat seleksi dalam satu populasi. Apabila keragaman genetik luas dan heritabilitas tinggi maka seleksi terhadap suatu sifat diharapkan menghasilkan kemajuan genetik yang tinggi (Falconer \& Mackay 1996).

Seleksi merupakan kegiatan utama dalam program pemuliaan tanaman untuk mengubah frekuensi gen dengan mengambil yang diinginkan dan membuang yang tidak diinginkan. Seleksi dapat dilakukan berdasarkan satu karakter dan beberapa karakter sekaligus. Agar seleksi efisien maka karakter yang digunakan sebagai karakter seleksi harus dipilih berdasarkan nilai heritabilitas, keragaman genetik serta keeratan hubungan dengan karakter hasil. Agar mengetahui keeratan hubungan karakter hasil dengan karakter lain dapat diketahui menggunakan analisis korelasi dan sidik lintas (Singh \& Chaudary 1979).

Pendugaan parameter genetik pada populasi sorgum hasil metode penggaluran single seed descent belum banyak dipelajari lebih lanjut sehingga diperlukan studi genetik serta penentuan karakter seleksi yang sesuai untuk mendapatkan galur sorgum berdaya hasil tinggi. Hasil pendugaan parameter genetik dan seleksi pada penelitian ini diharapkan mampu memberikan informasi mengenai penggunaan metode single seed descent sebagai alternatif dalam mendapatkan galur-galur sorgum harapan berdaya hasil tinggi. Serangkaian kegiatan penelitian akan dilakukan untuk membentuk galur sorgum yang memiliki daya hasil tinggi dengan memanfaatkan pendugaan parameter genetik dan seleksi. Alur penelitian disajikan pada Gambar 1.

\section{Tujuan Penelitian}

Penelitian ini bertujuan untuk: (1) mendapatkan informasi mengenai keragaan dan keragaman genetik populasi F4 dan F5 (B69 x Numbu) hasil metode penggaluran single seed descent, (2) mendapatkan informasi tentang keeratan hubungan antara karakter agronomi dengan hasil galur sorgum (B69 x Numbu), (3) melakukan seleksi galur-galur harapan sorgum (B69 x Numbu) berdaya hasil tinggi dan memiliki keseragaman yang rendah dalam galur. 


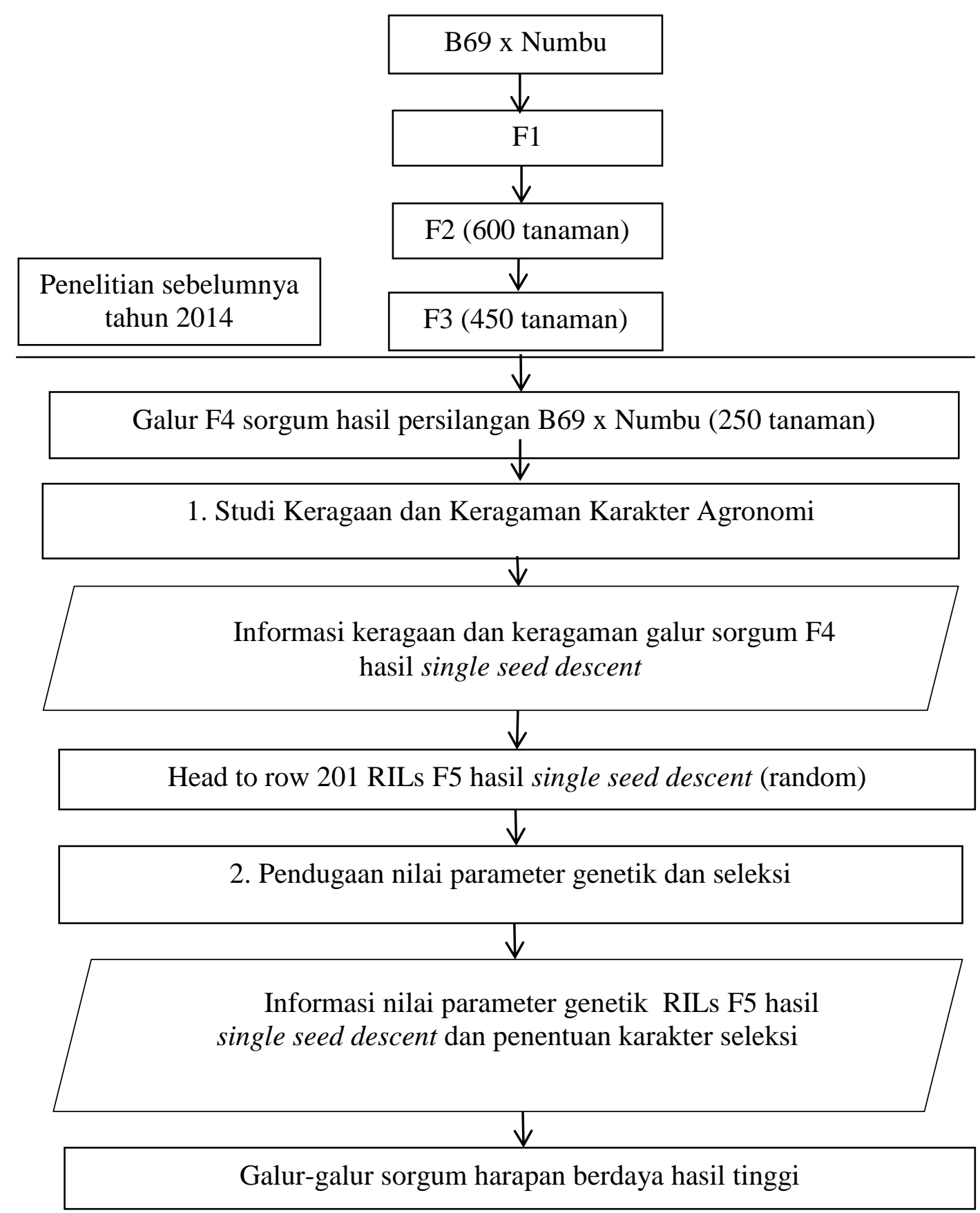

Gambar 1. Alur kegiatan penelitian. 


\section{TINJAUAN PUSTAKA}

\section{Klasifikasi dan Morfologi Sorgum ( Sorghum bicolor (L.) Moench)}

Sorgum merupakan tanaman pangan penting kelima di dunia setelah padi, gandum, jagung dan barley (Reddy et al. 2012). Sorgum mempunyai nama umum yang beragam, yaitu sorghum di Amerika Serikat dan Australia, durra di Afrika, jowar di India, bachanta di Ethiopia dan cantel di Jawa (Hoeman 2007). Sorgum dapat ditanam pada daerah dataran rendah dan subtropis. Kondisi optimum untuk pertumbuhan sorgum adalah suhu 20-30 ${ }^{\circ} \mathrm{C}$ dan curah hujan 400-600 mm (Dicko et al. 2006). Pertumbuhan tanaman sorgum akan terhambat dan memiliki umur yang panjang apabila ditanam dengan ketinggian $>500 \mathrm{~m}$ dpl (Acquaah 2007).

Sorgum termasuk Divisi Angiospermae yaitu jenis tumbuhan dengan biji tertutup, Kelas Monocotyledoneae yaitu jenis tumbuhan yang mempunyai biji berkeping satu dengan Subkelas Liliopsida, Ordo Poales yang dicirikan melalui bentuk tanaman terna dengan siklus hidup bersifat annual atau semusim, Famili Poaceae atau Gramineae yaitu tumbuhan jenis rumput-rumputan dengan karakteristik batang berbentuk silinder dengan buku-buku yang jelas, dan Genus Sorghum (Tjitrosoepomo 2000).

Sorgum memiliki tiga spesies, yaitu Sorghum halepense $(2 n=4 x=40)$, Sorghum propinquum $(2 \mathrm{n}=2 \mathrm{x}=20)$ dan Sorghum bicolor $(2 \mathrm{n}=2 \mathrm{x}=20)$. Sorgum yang dibudidayakan termasuk ke dalam Sorghum bicolor. Sorghum bicolor dibagi menjadi lima ras, yaitu kafir, caudatum, durra, guinea dan bicolor. Sorghum bicolor memiliki penampilan fenotipe yang sangat beragam, mulai dari tipe batang, tipe hijauan, tipe biji dan tipe sapu (Smith \& Frederiksen 2000)

Daun pada tanaman sorgum memiliki ukuran yang bervariasi, pada bagian atas daun umumnya lebih pendek dan lebih kecil (daun paling atas yang disebut daun bendera), pada bagian pertengahan bawah, ukuran daun sama panjang atau sedikit lebih panjang daripada ukuran daun pada dasar tanaman. Panjang Daun dapat mencapai lebih kurang $1 \mathrm{~m}$ dan lebar daun dapat bervariasi antara 10 sampai $15 \mathrm{~cm}$. Jumlah daun bervariasi, tanaman yang dapat beradaptasi dengan baik biasanya memiliki jumlah lebih kurang 14 daun, tetapi pada tanaman yang kurang mampu untuk beradaptasi dapat memiliki sebanyak 30 daun (House 1985).

Bunga tanaman sorgum terdiri dari malai (panicle), tangkai malai (peduncle), rangkaian bunga (racame), dan bunga (spikelet) (Acquaah 2007). Malai sorgum bervariasi tergantung pada varietas yang dapat dibedakan berdasarkan posisi, kerapatan, dan bentuk. Posisi malai sorgum memiliki tangkai yang tegak atau melengkung, berukuran panjang atau pendek (Dicko et al. 2006).. Berdasarkan kerapatan, malai sorgum ada yang kompak, longgar, dan intermediet. Berdasarkan bentuk, malai ada yang oval, silinder, elip, dan kerucut (Martin 1970).

Rangkaian bunga pada umumnya terdiri atas satu atau beberapa bunga. Ukuran rangkaian bunga beragam, bergantung pada jumlah buku dan panjang ruas yang terdapat di dalam rangkaian bunga, berkisar $1-8$ buku Terdapat $1500-4$ 000 bunga pada setiap malai (House 1985). setiap malai berisi 2000 biji yang tertutup oleh sekam (Acquaah 2007).

Berdasarkan bentuk malai dan tipe spikelet, sorgum diklasifikasikan ke dalam 5 ras yaitu ras Bicolor, Guenia, Caudatum, Kafir, dan Durra. Ras Durra yang umumnya berbiji putih merupakan tipe paling banyak dibudidayakan sebagai 
sorgum biji (grain sorghum) dan digunakan sebagai sumber bahan pangan. Diantara ras Durra terdapat juga varietas yang memiliki kadar gula batang tinggi disebut sebagai sorgum manis. Ras kafir, caudatum, dan guinea pada sorgum umumnya digunakan sebagai biomasa dan pakan ternak (Hoeman 2012).

Sorgum termasuk tanaman menyerbuk sendiri (self pollination), dimana pada setiap malai terdapat bunga jantan dan bunga betina. Proses penyerbukan dan fertilisasi terjadi apabila glume atau sekam dari masing-masing bunga membuka. Karena proses membukanya glume antara bunga jantan dan bunga betina tidak selalu bersamaan, maka pollen dapat viable untuk jangka waktu 10-15 hari (House 1985).

Tanaman sorgum memiliki sistem perakaran yang dalam dan memiliki banyak akar serabut. Sorgum memiliki tiga macam akar yaitu akar primer, akar sekunder dan akar tunjang atau akar udara. Akar primer muncul pertama kali pada saat berkecambah, akar sekunder berkembang dari buku pertama, akar ini berkembang menjadi sistem perkaran yang ektensif. Akar udara muncul kemudian pada buku paling rendah dan biasanya akan berkembang banyak jika tanaman tidak adaptif, akar ini tidak efektif dalam menyerap air dan nutrisi Akar primer bersifat sementara, secara cepat akan digantikan oleh akar sekunder, yaitu akarakar adventif yang lebih permanen (House 1985). Menurut Agustina et al. (2010) toleransi sorgum terhadap kekeringan disebabkan karena pada endodermis akar sorgum terdapat endapan silika yang berfungsi mencegah kerusakan akar pada kondisi kekeringan.

Batang sorgum umumnya padat dan kering. Kondisi yang menguntungkan menyebabkan ruas daun dan batang dapat berkembang dengan baik serta dapat menghasilkan batang yang lebih panjang. Batang terdiri dari ruas dan buku. penampang batang tampak oval atau bulat. Diameter batang bervariasi antara 0,5 dan $5 \mathrm{~cm}$ dan menjadi semakin sempit diameternya pada ujung atas. Panjang batangnya juga bervariasi yaitu sekitar 0,5 sampai $4 \mathrm{~m}$. ruas ditutupi oleh lapisan lilin tebal memberikan warna biru-putih. Lapisan ini dapat berfungsi mengurangi transpirasi dan meningkatkan toleransi kekeringan tanaman (House 1985).

Sorgum memiliki bentuk biji bulat dengan ukuran 4-8 $\mathrm{mm}$. Diantara kulit (pericarp) dan endosperm dilapisi oleh lapisan testa dan aleuron. Lapisan testa termasuk pada bagian perikarp dan lapisan aleuron termasuk pada bagian dari endosperm. Komposisi bagian biji sorgum terdiri atas kulit luar $8 \%$, lembaga $10 \%$ dan endosperm $82 \%$. Warna biji sorgum sangat bervariasi mulai dari putih, kuning, merah, coklat dan ungu (Aquaah 2007)

Warna biji dipengaruhi oleh warna dan ketebalan kulit (pericarp), terdapatnya testa serta tekstur dan warna endosperm. Biji sorgum tertutup oleh sekam, presentase penutupan biji sorgum oleh sekam bervariasi. Warna sekam pada saat masak bervariasi di antaranya putih, kuning/coklat muda, coklat, merah, ungu, hitam, abu-abu. (ICRISAT 1993).

Tanaman sorgum memiliki kemampuan untuk tumbuh kembali setelah dipanen disebut ratoon, setelah panen akan tumbuh tunas baru yang tumbuh dari bagian batang di dalam tanah, oleh karena itu pangkasannya harus tepat di atas permukaan tanah. Ratoon sorgum dapat dilakukan 2 - 3 kali, apabila dipelihara dan dipupuk dengan baik, hasil ratoon dapat menyamai hasil panen pertama (House 1985). 


\section{Metode Penggaluran Single Seed Descent}

Keragaman genetik yang tinggi merupakan salah satu syarat yang dalam perbaikan genetik tanaman. Keragaman genotipe pada tanaman disebabkan karena rekombinasi gen, keragaman dalam jumlah kromosom dan mutasi (Poehlman \& Sleper 2006). Rekombinasi gen dapat terjadi melalui hibridisasi yaitu persilangan antara tanaman yang berbeda secara genetik. Melalui hibridisasi, pemulia tanaman dapat menggabungkan sifat-sifat yang diinginkan dari tetua pada keturunannya.

Seleksi merupakan kegiatan utama dalam pemuliaan tanaman. Seleksi secara prinsip merupakan salah satu upaya merubah frekuensi gen dengan mengambil yang diinginkan dan membuang yang tidak diinginkan (Falconer \& Mackay 1996). Efisensi seleksi sangat ditentukan oleh karakter seleksi yang digunakan sehingga sebelum melakukan seleksi perlu terlebih dahulu ditentukan kriteria seleksi (Chahal \& Gosal 2003).

Metode penggaluran pada tanaman menyerbuk sendiri dapat dibagi menjadi beberapa metode, yaitu metode silsilah / pedigree, metode bulk dan metode turunan biji tunggal / single seed descent. Tabel 1 menjelaskan tentang perbedaan prinsip seleksi ketiga metode penggaluran pada tanaman menyerbuk sendiri (Poehlman \& Sleper 1996).

Tabel 1 Metode penggaluran untuk tanaman menyerbuk sendiri.

\begin{tabular}{lll}
\hline No & Metode penggaluran & Prinsip metode penggaluran terhadap seleksi \\
\hline 1 & Silsilah / pedigree & Seleksi dilaksanakan di generasi awal, seleksi \\
& & berulang dilakukan terhadap individu terbaik \\
& dari famili terbaik sampai tercapai tingkat \\
& & homozigositas tinggi dan silsilah setiap galur di \\
& & \\
& &
\end{tabular}

Metode seleksi SSD cocok untuk tanaman menyerbuk sendiri yang memiliki umur pendek. Prosedur SSD mempunyai tujuan mempertahankan keturunan dari sejumlah besar tanaman F2 dengan mengurangi hilangnya genotip selama generasi segregasi (Roy 2000). Metode SSD banyak diterapkan pada tanaman berpolong, misalnya tanaman kedelai. Secara prinsip individu tanaman terpilih dari suatu persilangan pada F2 selanjutnya ditanam cukup satu biji satu keturunan. Cara ini dilakukan sampai generasi yang ke lima (F5) atau enam (F6). Bila pada generasi tersebut sudah diperoleh tingkat keseragaman yang diinginkan maka pada generasi berikutnya pertanaman tidak dilakukan satu biji satu keturunan tapi ditingkatkan menjadi satu baris satu populasi keturunan, kemudian menjadi satu plot satu populasi keturunan (Mangoendidjojo 2003). 
Metode single seed descent menghasilkan keragaman maksimum pada saat generasi akan diseleksi dan meningkatkan segregan transgresif. Langkah awal pada metode single seed descent dilakukan untuk membentuk galur-galur homozigot dengan keragaman genetik yang luas. Seleksi yang tidak dilakukan pada generasi awal mengakibatkan tidak terjadi perubahan frekuensi gen, tetapi hanya mengubah frekuensi genotipe. Hal ini mengakibatkan dari generasi ke generasi frekuensi genotipe homozigot akan meningkat, sedangkan frekuensi genotipe heterozigot menurun sehingga seleksi pada populasi penggaluran hasil single seed descent efektif dilakukan pada generasi lanjut F5/F6 (Roy 2000).

Kelebihan metoda single seed descent adalah; keperluan lahan lebih sempit karena benih yang ditanam satu biji dari setiap tanaman, pencatatan dan pengamatan jauh lebih sederhana, dimungkinkan untuk menanam sejumlah generasi tiap tahun melalui pengendalian lingkungan, misalnya dalam rumah kaca, tanaman yang baik tidak terbuang karena tidak dilakukan seleksi pada generasi awal, seleksi alam pada generasi awal dapat meningkatkan frekuensi gen-gen baik Kelemahan metoda single seed descent adalah; identitas unggul dari generasi F2 tidak diketahui, bila pemilihan sejak awal generasi tidak jeli dan kurang tajam maka dapat mengakibatkan hilangnya beberapa individu tanaman yang superior karena pemilihan hanya berdasarkan satu tanaman tunggal, seleksi alam pada generasi awal dapat menghilangkan genotipe-genotipe baik, jumlah tanaman pada generasi lanjut sangat banyak sehingga menyulitkan dalam seleksi dan memerlukan lahan sangat luas (Chahal \& Gosal 2003).

Proses seleksi single seed descent yang dilakukan adalah sebagai berikut; persilangan antara dua tetua, kemudian benih hasil persilangan ditanam sebagai tanaman F1. Dari hasil tanaman F1 kemudian ditanam satu benih dari setiap satu tanaman sebagai tanaman F2. Pada tanaman F2 yang berasal dari benih F1, benih ditanam semuanya tanpa ada seleksi untuk satu biji dari satu individu tanaman terpilih., begitu seterusnya sampai pada generasi F4 atau F5. Pada F4 atau F5 dilakukan pemilihan, tanaman yang terpilih ditanam pada pertanaman F5 atau F6 satu baris pada setiap individu, kemudian dilakukan pemilihan terhadap barisbaris tanaman yang menunjukan keunggulan. Pada tahun seleksi berikutnya F7 mulai dilakukan pengujian pendahuluan mengenai daya hasil dan sifat-sifat lain. Pengujian lanjut dapat dilakukan berdasarkan hasil evaluasi pertanaman pada F7 (Mangoendidjojo 2003).

\section{Parameter Genetik dan Seleksi}

Pendugaan parameter genetik terdiri atas nilai variabilitas genetik, nilai heritabilitas, kemajuan genetik, nilai korelasi fenotipe dan genotipe, merupakan informasi dasar bagi upaya perbaikan suatu karakter tanaman melalui seleksi. Penampilan fenotipik suatu karakter tanaman merupakan hasil dari faktor genetik, lingkungan, dan interaksi antara faktor genetik dan lingkungan (Falconer \&Mackay 1996).

Keragaman pada populasi dapat dilihat dari keragaman fenotipe dan keragaman genotipenya. Keragaman fenotipe merupakan keragaman yang dapat diukur atau dilihat langsung pada karakter yang diamati. Keragaman genotipe dapat diduga melalui analisis ragam. Suatu populasi yang memiliki keragaman fenotipe yang luas belum tentu memiliki keragaman genotipe yang luas karena dapat dipengaruhi oleh faktor lingkungan (Roy 2000). 
Nilai heritabilitas merupakan suatu petunjuk seberapa besar suatu karakter atau sifat dipengaruhi oleh faktor genetik. Nilai heritabilitas yang tinggi menunjukkan faktor genetik lebih berperan dalam mengendalikan suatu sifat dibandingkan faktor lingkungan (Roy 2000). Nilai ini sangat penting dalam pemuliaan dan seleksi karakter kuantitatif. Efektif atau tidaknya seleksi tanaman yang berdaya hasil tinggi dari suatu populasi tergantung seberapa jauh keragaman hasil yang disebabkan faktor genetik yang diwariskan pada turunannya dan seberapa jauh pula keragaman hasil yang disebabkan lingkungan tumbuh (Poehlman \& Sleper 2006).

Nilai heritabilitas suatu sifat akan beragam antar populasi. Perbedaan ini disebabkan oleh perbedaan faktor genetik (ragam genetik), perbedaan lingkungan (ragam lingkungan), metode, dan jumlah tampilan data yang digunakan. Heritabilitas merupakan salah satu parameter genetik yang digunakan untuk menduga kemajuan dalam perbaikan suatu karakter tanaman. Heritabilitas dapat digolongkan menjadi dua macam, yaitu heritabilitas arti luas dan heritabilitas arti sempit.

Heritabilitas arti luas merupakan hubungan total ragam genetik dengan lingkungan. Heritabilitas arti sempit hanya mempertimbangkan keragaman yang disebabkan oleh peranan gen aditif sebagai bagian dari keragaman genetik total. Secara umum, heritabilitas arti sempit mendapat perhatian khusus karena pewarisan sifat dari tetua kepada keturunannya merupakan pengaruh aditif dari gen sehingga fenotipe tidak tergantung dari adanya interaksi antar alel (Falconer \& Mackay 1996).

Banyak metode yang dapat digunakan untuk menduga nilai heritabilitas dan komponen ragam. Heritabilitas dapat diduga dengan menggunakan perhitungan ragam turunan, dengan regresi parent-offspring, perhitungan komponen ragam dari analisis ragam dan dengan rancangan hibridisasi (Koumber dan El-Gammaal 2012). Nilai duga heritabilitas memiliki beberapa kegunaan, di antaranya adalah untuk mengetahui respon karakter yang diinginkan terhadap tekanan seleksi dan untuk mengetahui prediksi respon seleksi. Semakin tinggi nilai heritabilitas, makin tinggi pula respon seleksi yang menunjukkan semakin efektifnya seleksi. Heritabilitas berfungsi untuk menentukan besarnya populasi yang dibutuhkan agar dapat dilakukan suatu seleksi dan menentukan alternatif variasi jenis seleksi (Roy 2000).

Seleksi pada karakter kuantitatif sulit dilakukan karena pengamatan dilakukan pada penampilan luar tanaman. Penampilan yang terlihat belum tentu disebabkan oleh faktor genetik, tetapi perbedaan tersebut dapat disebabkan oleh faktor lingkungan. Oleh sebab itu, perlu diketahui seberapa besar faktor genetik dan faktor lingkungan mempengaruhi karakter yang muncul (Syukur et al. 2012). Falconer dan Mackay (1996) menambahkan bahwa karakterter yang diharapkan dapat diwariskan ke generasi selanjutnya memiliki nilai heritabilitas yang tinggi dan berkorelasi positif.

Pendugaan kemajuan seleksi bergantung pada heritabilitas, intensitas seleksi dan simpangan baku fenotipe populasi yang diseleksi. Jika heritabilitasnya besar maka kemajuan seleksi yang akan diperoleh akan semakin baik. Intensitas seleksi merupakan ukuran pembakuan terhadap diferensial seleksi sehingga dapat digunakan untuk membandingkan kekuatan seleksi terhadap dua macam karakter atau lebih yang berbeda satuan pengukurannya. Intensitas seleksi dipengaruhi oleh 
keragaman genetik dan jumlah individu keturunan. Seleksi pada populasi dengan keragaman tinggi cenderung memerlukan intensitas seleksi lebih rendah dibandingkan pada populasi dengan keragaman rendah. Semakin kecil proporsi individu terseleksi maka semakin tinggi intensitas seleksinya (Syukur et al. 2012).

Respon seleksi adalah perubahan nilai rata-rata fenotipe dari generasi berikutnya, sebagai akibat dari adanya seleksi terhadap populasi. Respon seleksi menjelaskan suatu perubahan antar generasi yang linear, diikuti dengan penurunan respon sampai batas seleksi tercapai. Penurunan respon selanjutnya muncul karena adanya random drift dalam populasi terbatas ketika pengaruh dominan muncul. Respon seleksi dan batas seleksi sangat tergantung pada intensitas seleksi, struktur genetik dalam populasi, dan lingkungan tempat seleksi dilakukan (Reddy 1996).

Pemuliaan tanaman seperti tanaman menyerbuk sendiri akan menghasilkan galur murni. Selfing yang dilakukan pada tanaman homozygot akan menghasilkan genotip yang homozigot dan selfing yang dilakukan pada tanaman heterozygot akan menghasilkan segregasi yang akan yang akan meningkatkan proporsi genotip homozygot dan menurunkan proporsi heterozygot. Hasil dari selfing ini akan menghasilkan terakumulasinya gen aditif yang homozygot dan aksigen epistatis akan berkurang (Chalal \& Gosal 2003).

Berdasarkan karakter yang menjadi tujuan seleksi, seleksi dibagi menjadi seleksi langsung dan seleksi tidak langsung. Seleksi langsung ditujukan untuk karakter-karakter yang menjadi tujuan perbaikan secara langsung (karakter seleksi) seperti daya hasil. Sementara seleksi tidak langsung atau dikenal dengan seleksi menggunakan karakter sekunder merupakan karakter-karakter yang berhubungan secara genetik dengan karakter yang menjadi tujuan perbaikan. Umumnya seleksi tidak langsung digunkan untuk memperbaiki karakter-karakter yang bertalian dengan sifat toleran di lingkungan bercekaman baik biotik maupun abiotik (Syukur et al. 2012).

Berdasarkan jumlah karakter yang dilibatkan dalam seleksi, seleksi dibedakan menjadi dua yaitu seleksi karakter tunggal dan seleksi simultan. Perbaikan dan pemilihan genotipe yang hanya didasarkan kepada sifat tunggal merupakan definisi dari seleksi sifat tunggal. Sementara pemilihan dan evaluasi lebih dari satu sifat kuantitatif secara serempak merupakan definisi dari seleksi simultan. Seleksi tandem, seleksi taraf penyisihan bebas (independent culling level), dan seleksi berbasis indeks merupakan metode-metode seleksi karakter berganda (Acquaah 2007). Seleksi karakter berganda lebih efisien dan perolehan kemajuan genetiknya lebih tinggi dibanding seleksi karakter tunggal. Selain itu seleksi karakter berganda juga dapat menghasilkan varietas dengan karakteristik ideal untuk semua sifat amatan (Sumarno \& Zuraida 2006).

Karakter-karakter kuantitatif seperti karakter yang berhubungan erat dengan pertumbuhan tanaman atau hasil panen merupakan karakter-karakter yang sangat dipengaruhi oleh lingkungan. Karakter kuantitatif dikendalikan oleh banyak gen dimana pengaruh masing-masing gen terhadap penampilan karakter (fenotipe) lebih kecil dan bersifat aditif. Gen-gen tersebut secara bersama-sama mempunyai pengaruh yang lebih besar dari pengaruh lingkungan. Gen-gen yang demikian disebut gen minor.

Aksi gen minor ditentukan oleh bentuk interaksi yang terjadi baik interaksi antar alel pada lokus yang sama. Untuk karakter kuantitatif maka interaksi antar alel dapat terjadi dalam bentuk interaksi aditif dan dominan maupun interaksi 
antar alel pada lokus yang berbeda (epistasis). Keragaman fenotipe dari karakter kuantitatif tidak dapat dikelaskan dengan jelas dan cenderung membentuk sebaran yang kontinyu karena dikendalikan oleh banyak gen. Seleksi terhadap karakter kuantitatif tidak didasarkan pada visual tetapi pada hasil analisis statistic (Falconer \& Mackay 1996)

Salah satu yang perlu diperhatikan pada populasi yang akan diseleksi adalah sebaran frekuensi populasi yang dimiliki. Informasi sebaran frekuensi penting bagi pemulia untuk mengetahui bias atau tidaknya pendugaan kemajuan seleksi yang dilakukan terhadap suatu karakter. Pendugaan kemajuan seleksi akan bias apabila dilakukan pada karakter memiliki penjuluran ke kiri atau kekanan pada sebaran datanya.

Sebaran data frekuensi yang menyimpang dari sebaran normal akan sangat berpengaruh terhadap proses seleksi pada generasi berikutnya (Bari 1998). Sebaran data yang tidak menyebar normal disebabkan adanya pengaruh gen-gen non aditif seperti gen epistatis maupun dominan. Aksi gen tersebut pada tanaman menyerbuk sendiri mengakibatkan terjadinya interaksi antar gen-gen sehingga pada generasi berikutnya proporsi homozigositas akan lebih lambat tercapai (Falconer \& Mackay 1996).

Karakter kuantitatif pada tanaman memiliki nilai skewness negatif (menjulur ke kiri) dan skewness positif (menjulur ke kanan). Penjuluran sebaran genotipe disebabkan oleh adanya pengaruh epistatis, dominan dan interaksi GxE. Jika sebaran data memiliki penjuluran ke kanan, maka seleksi akan memberikan kemajuan genetik yang rendah dari yang diharapkan begitu juga sebaliknya. Sebaran frekuensi memiliki nilai skewness positif dan negatif, maka kemajuan pengkuran kemajuan genetik menggunakan asumsi bahwa data menyebar normal harus dilakukan secara hati-hati (Roy 2000)

Pembacaan sebaran frekuensi genotipe terletak pada nilai skewness dan kurtosis. Menurut Roy (2000) skewness dan kurtosis lebih kuat untuk mendeteksi interaksi gen seperti aksi gen epistatis komplementer dan episttis duplikat pada karakter yang diamati dibandingkan tekhnik sidik ragam (ANOVA). Nilai skewness adalah nilai penjuluran dari sebaran. Skewness dapat menunjukan adanya epistatis atau tidak yang mempengaruhi suatu karakter. Menurut Welsh (2005) epistatis adalah interaksi antar alel pada lokus yang berbeda. Epistatis ini terjadi karena munculnya hasil ekspresi dari suatu gen membutuhkan kehadiran alel tertentu pada lokus lain. Di lain pihak epistatis duplikat terjadi karena dua atau beberapa gen memproduksi protein yang sama dan menghasilkan fenotipe yang sama.

Pendugaan ada tidaknya aksi gen epistatis dari pola sebaran frekuensi sangat penting diketahui pada program seleksi. aksi gen tersebut merupakan salah satu faktor yang menyebabkan efek bias terhadap seleksi suatu karakter. Kurtosis adalah nilai yang menunjukan tipe sebaran frekuensi. Kurtosis bernilai positif maka sebaran berbentuk leptokurtik dan karater tersebut dikendalikan oleh sedikit gen. Kurtosis bernilai negatif maka sebaran berbentuk platykurtik dan karakter tersebut dikendalikan oleh banyak gen (Roy 2000).

Keragaman genetik yang luas untuk beberapa karakter pada populasi disebabkan latar belakang genetik populasi yang berbeda dan arah seleksi yang diarahkan (Syukur et al. 2011). Keragaman genetik suatu populasi tergantung pada apakah populasi tersebut merupakan generasi bersegregasi dari suatu 
persilangan, pada generasi ke berapa, dan bagaimana latar belakang genetiknya; (Pinaria et al. 1995). Keragaman genetik yang luas, nilai duga heritabilitas yang tinggi serta kemajuan genetik yang tinggi memberikan peluang kemajuan seleksi yang efektif. Disamping itu kemajuan seleksi yang efektif didukung adanya korelasi antara suatu karakter dengan karakter target (Sa'diyah et al. 2010).

Korelasi adalah koefisien yang menggambarkan tingkat keeratan hubungan linear antara dua peubah. Besaran dari koefisien korelasi tidak menggambarkan hubungan sebab akibat antara dua peubah atau lebih tetapi semata mata menggambarkan keterikatan linear antara peubah (Mattjik \& Sumertajaya 2006). Korelasi antar karakter sangat bermanfaat dalam memberikan informasi tentang karakter agronomi yang mempengaruhi karakter hasil. Karakter yang berkorelasi nyata dengan hasil dapat dijadikan sebagai karakter seleksi untuk mendapatkan tanaman yang mampu berproduksi tinggi. (Poespodarsono 1988).

Karakter yang dikorelasikan apabila memiliki heritabilitas yang rendah, maka korelasi fenotipnya ditentukan oleh korelasi lingkungan, jika heritabilitasnya tinggi maka korelasi genetik lebih penting untuk diketahui. Korelasi fenotipik tidak hanya berasal dari korelasi genotip saja. Nilai korelasi fenotip merupakan derjat hubungan karakter yang langsung diukur, sedangkan nilai korelasi genotip merupakan derjat keeratan hubungan antara total rata-rata dari pengaruh gennya (Falconer \& Mackay 1996).

Analisis korelasi memiliki kekurangan dimana analisis ini hanya menggambarkan hubungan antara komponen hasil dan tidak bisa menjelaskan seberapa besar pengaruh langsung dan pengaruh tidak langsung terhadap komponen hasil. Dengan analisis lintasan (sidik lintas) masalah ini dapat diatasi, karena masing-masing sifat yang dikorelasikan dengan hasil dapat diurai menjadi pengaruh langsung dan tidak langsung (Singh \& Chaudary 1979).

Hubungan kausal antara antara peubah bebas dan peubah tak bebas dapat diketahui dengan menggunakan analisis sidik lintas (pathway analysis). Analisis ini dapat mengetahui pengaruh langsung dan tidak langsung antara variabel bebas dengan variabel tak bebas (hasil) sehingga akan lebih mudah dalam melakukan seleksi, khususnya karakter yang berpengaruh langsung terhadap hasil dan juga sebagai landasan bagi pemulia dalam program perbaikan tanaman (Singh \& Chaudary 1979).

Penjabaran hasil dari sidik lintas dilakukan dengan melihat nilai koefisien korelasi (r) dan nilai pengaruh langsungnya (C). Apabila koefisien korelasi dari suatu karakter bernilai positif akan tetapi pengaruh langsungnya bernilai negatif negatif, maka pengaruh tidak langsungnya yang lebih berperan terhadap korelasi tersebut. Apabila koefisien korelasi dari dua karakter nilainya hampir sama dengan pengaruh langsungnya, maka seleksi efektif dilakukan pada karakter tersebut (Singh \& Chaudary 1979).

Keuntungan dari analisis koefisien lintas adalah memungkinkan untuk memisahkan koefisien korelasi kedalam komponen-komponen koefisien lintas yang mengukur pengaruh langsung dan tidak langsung (Arshad et al. 2007). Pemanfaatan koefisien lintas telah mampu mengidentifikasi pengaruh langsung dan tidak langsung karakter vegetatif dan generatif terhadap daya hasil aksesi pinang Sumut-2 (Miftahorrachman 2005), daya hasil gandum (Wardani 2014; Yamin 2014; Mardiana 2015), dan kedelai (Wirnas 2006). 


\title{
3 KERAGAAN DAN KERAGAMAN POPULASI F4 SORGUM HASIL PENGGALURAN DENGAN METODE SINGLE SEED DESCENT
}

\author{
Performance and Variation of F4 Sorgum Population \\ Developed by Single Seed Descent
}

\begin{abstract}
This study aimed to obtain information on the performance and diversity of agronomic characters sorghum population F4 method results single seed descent from crosses B69 x Numbu. Genotypes tested the population F4 and 2 control the B69 and Numbu. The experiment was conducted at the experimental Leuwikopo, Laboratory of Plant Breeding, Department of Agronomy and Horticulture, Bogor Agricultural University from February to Mai 2014. The results show all the characters that were observed to have high heritability. Character stem diameter, panicle weight and grain weight panicle $e^{-1}$ has a broad genetic diversity, whereas the other characters have moderate genetic diversity. The distribution of the data shows that there segregan transgesif populations F4 for agronomic characters. Data shows the distribution pattern observed agronomic characters have normal distribution, controlled polygenic and additive gene action. The weight of panicle, panicle circumference and diameter of the stem correlated real, positive and strong with grain weight panicle ${ }^{-1}$.
\end{abstract}

Keyword: sorghum, agronomic performance, heritability, genetic variation

\begin{abstract}
Abstrak
Penelitian ini bertujuan untuk memperoleh informasi mengenai keragaan dan keragaman karakter agronomi populasi sorgum $\mathrm{F} 4$ hasil metode single seed descent dari persilangan B69 x Numbu. Genotipe yang diuji yakni populasi F4 dan 2 kontrol yakni B69 dan Numbu. Penelitian dilaksanakan di Kebun Percobaan Leuwikopo, Laboratorium Pemuliaan Tanaman, Departemen Agronomi dan Hortikultura, Institut Pertanian Bogor pada bulan Februari sampai Mai 2014. Hasil penelitian menunjukkan seluruh karakter yang diamati memiliki heritabilitas yang tinggi. Karakter diameter batang, bobot malai dan bobot biji malai ${ }^{-1}$ memiliki keragaman genetik luas, sedangkan karakter lainnya memiliki keragaman genetik sedang. Sebaran data menunjukkan bahwa terdapat segregan transgesif pada populasi F4 untuk karakter agronomi yang diamati. Karakter agronomi yang diamati memiliki sebaran normal, dikendalikan oleh banyak gen dan aksi gen aditif. Bobot malai, lingkar malai, dan diameter batang berkorelasi nyata, positif dan kuat dengan bobot biji malai ${ }^{-1}$.
\end{abstract}

Kata kunci: sorgum, keragaan karakter agronomi, heritabilitas, keragaman genetik 


\section{Pendahuluan}

Sorgum (Sorghum bicolor (L.) Moench) merupakan salah satu tanaman serealia yang berpotensi untuk dikembangkan di Indonesia. Tanaman ini dikenal sebagai palawijaya dengan sebutan cantel atau gandrung. Tanaman asal Afrika ini awalnya di Indonesia ditanam sebagai tanaman sela. Tanaman sorgum memiliki potensi untuk dikembangkan sebagai sumber bahan pangan (Hoeman 2007). Tanaman ini memiliki kandungan karbohidrat $73 \mathrm{~g}, 11 \mathrm{~g}$ protein, $3.3 \mathrm{~g}$ lemak, 28 mg kalsium, $287 \mathrm{mg}$ fosfor, $4.4 \mathrm{mg}$ zat besi, $11.2 \%$ air, dan $2.3 \%$ serat dalam 100 g sorgum (Beti et al. 1990). Biji sorgum dapat dikonsumsi dalam bentuk roti, bubur minuman, dan keripik (Dicko et al. 2006).

Selama ini produksi sorgum sebagai sumber bahan pangan di Indonesia masih rendah. Potensi hasil sorgum di Indonesia hanya mencapai 2.1 ton $\mathrm{ha}^{-1}$ (Ditjen Tanaman Pangan 2013). Menurut Hoeman (2008) bila faktor lingkungan bukan menjadi faktor pembatas, potensi hasil sorgum dapat melebihi 11 ton $\mathrm{ha}^{-1}$ dengan rata-rata hasil antara 7-9 ton $\mathrm{ha}^{-1}$. Penelitian dan pengembangan lebih lanjut masih diperlukan untuk dapat menghasilkan varietas unggul sorgum dengan potensi hasil yang lebih baik lagi di Indonesia.

Varietas unggul sorgum berdaya hasil tinggi dari populasi bersegregasi dalam program pemuliaan tanaman dapat dihasilkan melalui persilangan dan diikuti dengan penggaluran serta seleksi. Salah satu metode penggaluran yang digunakan untuk tanaman menyerbuk sendiri adalah metode single seed descent (Chahal \& Gosal 2003). Metode single seed descent sangat efektif untuk meningkatkan daya hasil dibanding metode bulk (Gill et al. 2000).

Prinsip metode single seed descent adalah menangani populasi bersegregasi selama beberapa generasi dengan melakukan kegiatan seleksi pada generasi lanjut sehingga jumlah individu diharapkan sama sampai mencapai tingkat homozigositas yang diinginkan. Individu tanaman terpilih dari hasil persilangan pada F2 ditanam satu biji satu keturunan, sampai mencapai tingkat keseragaman yang diinginkan pada generasi lanjut F5/F6 (Roy 2000). Metode single seed descent secara teknis tidak memerlukan lahan yang luas, membutuhkan waktu dan tenaga lebih sedikit serta pencatatan dan pengamatan jauh lebih sederhana (Syukur et al. 2012).

Beberapa penelitian yang menggunakan metode single seed descent untuk meningkatkan hasil pada berbagai tanaman seperti; tanaman gandum (Lalic et al. 2003), tanaman padi (Kanbar et al. 2011) dan tanaman kedelai (Komariah et al .1992, Miladinovic et al. 2011, Sihaloho 2015). Menurut hasil penelitian Miladinovic et al. (2011) dan Sihaloho (2015) penggunaan metode single seed descent dapat mempertahankan heritabilitas tinggi dan keragaman genetik yang luas di generasi F4 kedelai pada karakter hasil. Hal ini memberi peluang untuk meningkatkan daya hasil terhadap komoditi sorgum melalui metode penggaluran single seed descent.

Departemen Agronomi dan Hortikultura, Fakultas Pertanian, Institut Pertanian Bogor telah melakukan persilangan B69 x Numbu pada tahun 2010. Hingga saat ini dari persilangan yang dilakukan telah menghasilkan populasi sorgum F4 melalui metode single seed descent. Metode ini untuk komoditi sorgum belum pernah dipelajari lebih lanjut. Populasi ini perlu dievaluasi untuk memperoleh informasi mengenai keragaan dan keragamannya. 


\section{Metode Penelitian}

\section{Waktu dan Tempat}

Penelitian ini dimulai pada bulan Februari sampai Mei 2014. Penelitian dilaksanakan di Kebun Percobaan Leuwikopo, Dramaga, Bogor, Jawa Barat.

\section{Bahan Genetik}

Bahan genetik yang digunakan adalah populasi F4 hasil persilangan B69 x Numbu dengan metode penggaluran single seed descent. Satu genotipe diwakili oleh satu individu tanaman. Varietas kontrol yang digunakan adalah kedua tetua yaitu Numbu dan B69.

\section{Prosedur Percobaan}

Pengolahan tanah dilakukan satu minggu sebelum tanam. Lahan percobaan dibagi menjadi menjadi dua petakan besar dengan luas total lahan $60 \mathrm{~m}^{2}$. Pembuatan lubang tanam dibuat dengan jarak Jarak tanam $75 \times 10 \mathrm{~cm}^{2}$. Percobaan dilaksanakan dengan melakukan penanaman satu galur diwakili satu individu. Pemberian pupuk urea dilakukan sebanyak dua kali yaitu pada saat penanaman sebanyak $50 \mathrm{~kg} \mathrm{ha}^{-1}$ bersamaan dengan pemberian pupuk SP-36 dan $\mathrm{KCl}$ masingmasing sebanyak $100 \mathrm{~kg} \mathrm{ha}^{-1}$. Pemupukan urea kedua dilakukan pada saat tanaman telah berumur 4 minggu setelah tanam dengan dosis $100 \mathrm{~kg} \mathrm{ha}^{-1}$. Panen dilakukan jika $80 \%$ tanaman dari satu galur sudah masak sempurna ditandai dengan munculnya lapisan hitam atau coklat pada biji dan apabila digigit biji sorgum pecah serta terasa tepungnya

\section{Pengamatan Karakter Agronomi}

1. Tinggi tanaman diukur dari pangkal batang di permukaan tanah hingga ujung malai pada saat menjelang panen.

2. Diameter batang diukur pada ruas ketiga pada saat fase pengisian biji dengan menggunakan jangka sorong pada saat menjelang panen.

3. Jumlah daun dihitung mulai dari buku kedua pada saat menjelang panen.

4. Panjang malai diukur dari leher malai sampai ke ujung malai saat panen.

5. Lingkar malai diukur pada bagian terbesar malai saat panen.

6. Bobot malai ditimbang setelah malai dikeringkan.

7. Bobot seribu biji ditimbang setelah biji dikeringkan dan dirontokan

8. Bobot biji malai ${ }^{-1}$ ditimbang setelah biji dikeringkan dan biji dirontokan.

\section{Analisis Data}

Penghitungan nilai tengah dilakukan untuk melihat keragaan masing-masing karakter serta melihat apakah terjadi perbaikan sifat pada galur yang diuji.

Sebaran frekuensi populasi F4 sorgum digunakan untuk melihat segregan transgresif serta kenormalan sebaran data. Menurut Roy (2000) kenormalan sebaran data dilihat dari nilai kemenjuluran (skewness), kemendataran (kurtosis). galat baku skewness $\left(\mathrm{S}_{\mathrm{ES}}\right)$, dan galat baku kurtosis $\left(\mathrm{S}_{\mathrm{EK}}\right)$. Nilai skewness dihitung menggunakan persamaan Roy (2000):

$$
\text { Skewness }(\mathrm{S})=\frac{\sum_{i=1}^{N}(Y \bar{i}-Y)^{3}}{(N-1) s^{3}}
$$


Uji statistik yang digunakan adalah sebagai berikut: $\mathrm{Zs}=\mathrm{S} / \mathrm{S}_{\mathrm{ES}}$ dengan nilai kritik $\mathrm{Z}_{0.05 / 2}=1.96$ dan $\mathrm{Z}_{0.01 / 2}=2.58$, dimana galat baku skewness sesuai dengan persamaan (Sing \& Chaudary 1979):

$$
\mathrm{S}_{\mathrm{ES}}=\sqrt{\frac{6 n(n-1)}{(n-2)(n+1)(n+3)}}
$$

Nilai kurtosis dihitung menggunakan persamaan Roy (2000):

$$
\operatorname{Kurtosis}(\mathrm{K})=\frac{\sum_{i=1}^{N}(Y \bar{i}-Y)^{4}}{(N-1) s^{4}}
$$

Uji statistik yang digunakan adalah sebagai berikut: $\mathrm{Zs}=\mathrm{S} / \mathrm{S}_{\mathrm{EK}}$ dengan nilai kritik $\mathrm{Z}_{0.05 / 2}=1.96$ dan $\mathrm{Z}_{0.01 / 2}=2.58$, dimana galat baku kurtosis sesuai dengan persamaan (Sing \& Chaudary 1979):

$$
\mathrm{S}_{\mathrm{EK}}=2(\mathrm{~K}) \times \sqrt{\frac{\mathrm{n}^{2}-1}{(n-3)(n+5)}}
$$

Interpretasi kemungkinan aksi gen dan jumlah gen berdasarkan Jayaramachandran et al. (2010) terdapat pada Lampiran 3. Analisis skewness dan kurtosis menggunakan software statistik SPSS 16.0.

Pendugaan komponen ragam terdiri atas ragam lingkungan, ragam genetik dan ragam fenotipe yang diperoleh berdasarkan (Baihaki 2000):

$\sigma_{e}^{2}=$ ragam lingkungan $=\left(\sigma_{P 1}^{2}+\sigma_{P 2}^{2}\right) / 2$

$\sigma_{p}^{2}=$ ragam fenotipe $\quad=$ ragam populasi $\mathrm{F} 4$

$\sigma_{g}^{2}=$ ragam genetik $\quad=\sigma_{p}^{2}-\sigma_{e}^{2}$

Setelah ragam diatas diperoleh, maka nilai heritabilitas dapat dihitung berasarkan rumus (Singh \& Chaudary 1979):

$$
h_{b s}^{2}=\frac{\sigma_{g}^{2}}{\sigma_{p}^{2}}
$$

Keterangan: $h_{b s}^{2}=$ heritabilitas arti luas, $\sigma_{g}^{2}=$ ragam genetik, $\sigma_{p}^{2}=$ ragam fenotipe heritabilitas dikategorikan mengikuti Singh dan Chaudary (1979) Tinggi $\left(\mathrm{h}^{2}>\right.$ $0,5)$; sedang $\left(0,2 \leq \mathrm{h}^{2} \leq 0,5\right)$; rendah $\left(\mathrm{h}^{2}<0,2\right)$.

Pendugaan koefisien keragaman genetik (KKG) digunakan untuk menduga luas atau tidaknya keragaman genetik yang dimiliki masing-masing karakter yang dihitung menurut rumus Knight (1979):

$$
K K G=\frac{\sqrt{\sigma_{g}^{2}}}{\bar{x}} \times 100 \%
$$

Keterangan: $\sigma_{g}^{2}=$ ragam genetik dan $\overline{\mathrm{X}}=$ rataan galur F4. Kriteria berdasarkan Anopri (2004) sebagai berikut, koefisien keragaman genetik dibagi dalam tiga kategori yaitu : sempit (0-10 \%), sedang (10-20\%), dan luas (> 20\%).

Analisis korelasi digunakan untuk mengetahui karakter yang berkaitan dengan bobot biji malai ${ }^{-1}$. Analisis korelasi dilakukan menggunakan program SAS.9.3. Analisis korelasi dihitung berdasarkan (Gaspersz 1992):

$$
r_{x y}=\frac{n \sum x_{1} y_{1}-\left(\sum x_{1}\right)\left(\sum y_{1}\right)}{\sqrt{\left[n \sum x_{1}^{2}-\left(\sum x_{1}\right)^{2}\right]\left[n \sum y_{1}^{2}-\left(\sum y_{1}\right)^{2}\right]}}
$$

Keterangan: $\mathrm{r}_{\mathrm{xy}}=$ koefisien korelasi antara karakter agronomi, $\mathrm{n}=$ banyaknya perlakuan; $\mathrm{x}_{1}=$ karakter agronomi; $\mathrm{y}_{1}=$ karakter bobot biji malai ${ }^{-1}$. 


\section{Hasil dan Pembahasan}

\section{Kondisi Umum}

Kisaran suhu di Kebun Percobaan Leuwikopo, Dramaga pada bulan Februari sampai Mei 2014 adalah $25.0-26.2^{\circ} \mathrm{C}$, ketinggian tempat $240 \mathrm{~m} \mathrm{dpl}$ dengan curah hujan 300-450 mm (BMKG 2014). Tanaman sorgum dapat tumbuh baik pada kisaran suhu $20-30^{\circ} \mathrm{C}$ (Dicko et al. 2006), ketinggian tempat $<500 \mathrm{~m}$ dpl (Acquaah 2007), dan curah hujan 300-450 mm (FAO 2001). Kondisi lingkungan ini secara umum sesuai dengan syarat pertumbuhan sorgum. Menurut Prabowo et al. (1998) curah hujan yang berkisar antara 350-488 mm merupakan curah hujan terbaik yang mampu menghasilkan biji 3.3 ton ha $^{-1}$ sehingga berdasarkan kondisi umum, penelitian ini memiliki peluang untuk menghasilkan sorgum dengan hasil biji yang lebih tinggi.
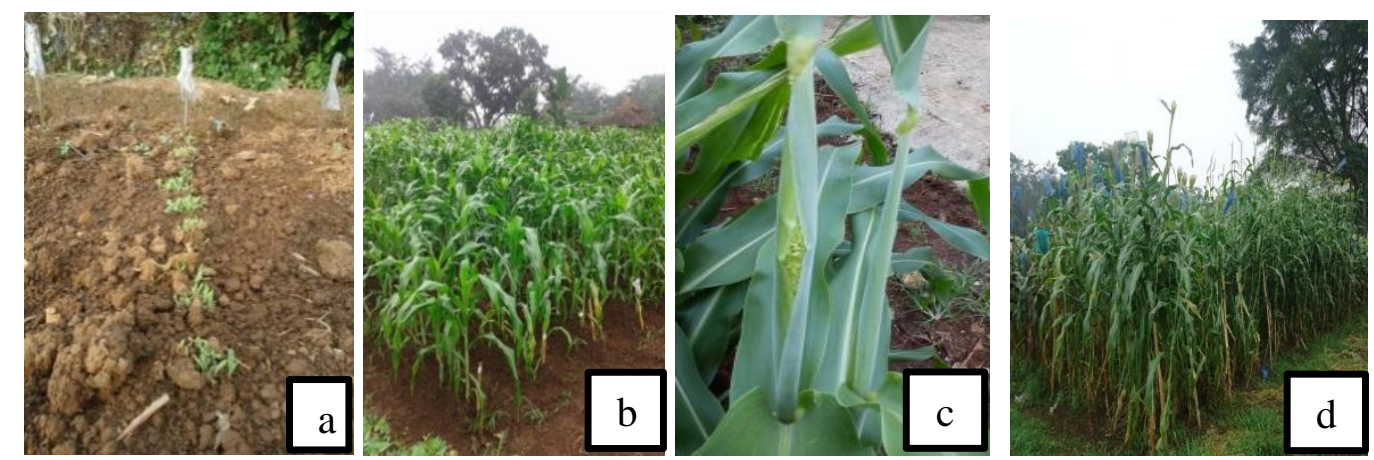

Gambar 2 Fase pertumbuhan tanaman sorgum; (a) vegetatif awal (b) vegetatif maksimum (c) generatif awal (d) generatif maksimum

Tahap pertumbuhan tanaman sorgum dimulai dengan fase vegetative awal, fase vegetatif maksimum, fase generative awal, dan fase generatif maksimum (Gambar 3.1). Fase vegetatif awal dan akhir ditandai dengan berkecambahnya biji sorgum dan munculnya daun bendera. Kondisi tanaman pada fase vegetatif ini menunjukan pertumbuhan yang lambat namun setelah dilakukan pengairan dan pemupukan kedua pada 4 MST tanaman mulai menunjukkan pertumbuhan yang baik. Fase generatif awal ditandai dengan pecahnya batang bagian bawah daun bendera yang berisi rangkaian bunga sorgum. Fase generatif maksimum ditandai dengan selesainya masa anthesis bunga yang dilanjutkan dengan pengisian biji. Memasuki umur 10 MST dilakukan penyungkupan untuk mengurangi kehilangan hasil akibat serangan hama burung pada saat pengisian biji.

Jumlah individu pada generasi F2, F3, dan F4 hasil metode SSD menunjukan penurunan. Populasi F2 sebanyak 600 individu, populasi F3 sebanyak 450 individu, sedangkan jumlah populasi F4 hanya sebanyak 225 individu. Menurut Sihaloho (2015) salah satu penyebab penurunan jumlah populasi hasil single seed descent diakibatkan adanya seleksi alam dengan tekanan seleksi berupa cekaman yang terkait dengan kondisi iklim. Hal ini ditambahkan oleh Fehr (1987) bahwa menurunnya jumlah genotipe pada suatu populasi disebabkan oleh ketidak mampuan tanaman menghasilkan biji atau menurunnya daya kecambah biji. 


\section{Keragaan Karakter Agronomi Tetua dan Populasi F4 Sorgum}

Materi genetik yang digunakan adalah benih sorgum generasi F4 dari persilangan antara B69 dan Numbu hasil metode penggaluran single seed descent yang berasal dari generasi F3 di lahan optimum. Populasi F3 merupakan hasil individu tanaman dari populasi F2 di lahan optimum. Tetua yang digunakan pada persilangan merupakan tetua yang memiliki keunggulan yang berbeda. Numbu memiliki keunggulan yaitu; tipe malai kompak, biji berukuran besar, mudah dirontokan, tolerant lahan masam, biji berwarna krem, daya adaptasi yang luas serta memiliki daya hasil 4-5 ton ha $^{-1}$ (Balitsereal 2014). Keunggulan galur B69 adalah memiliki tinggi tanaman pendek (Hoeman 2011). Menurut penelitian Rini (2014) dari berbagai persilangan yang dilakukan persilangan B69 x Numbu merupakan kombinasi persilangan yang terbaik untuk karakter hasil sehingga diharapkan terdapat galur-galur hasil persilangan yang memiliki daya hasil tinggi.

Karakter agronomi merupakan karakter yang terdiri dari karakter pertumbuhan dan hasil tanaman. Karakter agronomi yang diamati pada penelitian ini adalah adalah diameter batang, tinggi tanaman, jumlah daun, panjang malai, lingkar malai, bobot malai, bobot seribu biji, dan bobot biji malai ${ }^{-1}$. Pengamatan populasi F4 hasil penggaluran dengan metode single seed descent maupun kedua tetua terhadap karakter diameter batang, tinggi tanaman, dan jumlah daun dilakukan pada saat tanaman mencapai vegetatif maksimum, sedangkan karakter panjang malai, lingkar malai, bobot malai, bobot seribu biji, dan bobot biji malai ${ }^{-1}$ diamati setelah panen. Nilai tengah dari masing-masing karakter pada kedua tetua dapat dilihat pada Tabel 2.

Tabel 2 Keragaan karakter agronomi galur - galur tetua sorgum

\begin{tabular}{llrrc}
\hline \multicolumn{2}{c}{ Karakter } & B69 & Numbu & t-hitung \\
\hline Diameter batang & $(\mathrm{mm})$ & 15.6 & 15.7 & 0.1 \\
Tinggi tanaman & $(\mathrm{cm})$ & 178.8 & 254.5 & $22.1^{*}$ \\
Jumlah daun & $($ helai $)$ & 9.5 & 9.8 & 1.7 \\
Panjang malai & $(\mathrm{cm})$ & 22.6 & 19.4 & $5.1^{*}$ \\
Lingkar malai & $(\mathrm{cm})$ & 15.4 & 16.7 & $6.3^{*}$ \\
Bobot malai & $(\mathrm{g})$ & 57.0 & 82.3 & $7.1^{*}$ \\
Bobot seribu biji & $(\mathrm{g})$ & 25.9 & 36.8 & $15.0^{*}$ \\
Bobot biji malai & $(\mathrm{g})$ & 47.0 & 72.8 & $9.1^{*}$ \\
\hline
\end{tabular}

Keterangan: $*$ = berbeda nyata berdasarkan uji-t pada $\alpha=0.05$.

Berdasarkan uji t pada taraf 5\% diketahui bahwa kedua tetua memiliki keragaan yang berbeda untuk karakter tinggi tanaman, panjang malai, lingkar malai, bobot malai, bobot seribu biji, dan bobot biji malai ${ }^{-1}$ (Tabel 2). Disamping itu nilai tengah karaker agronomi yang diamati pada numbu lebih baik dibandingkan B69, kecuali panjang malai. Hasil ini sesuai dengan penelitian Sulistyowati (2015) pada tanah masam. Perbedaan keragaan karakter agronomi di antara kedua tetua disebabkan oleh latar belakang genetik diantara kedua tetua dimana B69 merupakan galur yang berasal dari varietas Durra yang diradiasi sinar gamma dosis 200 Gy (Hoeman 2011) sedangkan Numbu merupakan varietas nasional hasil introduksi dari India (Balitsereal 2011). 
Tabel 3 Keragaan karakter agronomi tetua dan populasi F4 sorgum hasil persilangan B69 x Numbu.

\begin{tabular}{|c|c|c|c|c|}
\hline \multirow{2}{*}{ Karakter } & \multicolumn{2}{|c|}{ Rata-rata tetua } & \multirow{2}{*}{$\begin{array}{c}\text { Populasi } \\
\text { F4 }\end{array}$} & \multirow{2}{*}{$\begin{array}{c}\text { Kisaran } \\
\text { Populasi F4 }\end{array}$} \\
\hline & Numbu & B69 & & \\
\hline Diameter batang (mm) & $15.7 \pm 1.5$ & $15.6 \pm 1.5$ & 16.5 & $9.0-25.0$ \\
\hline Tinggi tanaman $(\mathrm{cm})$ & $254.5 \pm 6.2$ & $178.8 \pm 14.0$ & 224.7 & $123.0-300.0$ \\
\hline Jumlah daun (helai) & $10.0 \pm 0.6$ & $10.0 \pm 0.5$ & 9.7 & $7.0-12.0$ \\
\hline Panjang malai $(\mathrm{cm})$ & $19.4 \pm 0.9$ & $22.6 \pm 2.6$ & 21.2 & $12.0-29.0$ \\
\hline Lingkar malai $(\mathrm{cm})$ & $16.7 \pm 1.3$ & $15.4 \pm 0.9$ & 16.4 & $9.0-24.0$ \\
\hline Bobot malai (g) & $82.3 \pm 13.1$ & $57.0 \pm 8.9$ & 78.2 & $8.7-157.5$ \\
\hline Bobot seribu biji (g) & $36.8 \pm 2.4$ & $25.9 \pm 2.2$ & 30.3 & $16.7-41.5$ \\
\hline Bobot biji malai $^{-1}(\mathrm{~g})$ & $72.8 \pm 10.1$ & $46.9 \pm 7.7$ & 67.2 & $6.3-139.6$ \\
\hline
\end{tabular}

Keragaan karakter agronomi populasi F4 sorgum terdapat pada Tabel 3. Hasil percobaan menunjukkan bahwa diameter batang populasi F4 lebih tinggi dibandingkan kedua tetua. Keragaan ini menunjukkan bahwa sebagian besar diameter batang populasi F4 sorgum yang diuji berada di atas nilai tengah varietas Numbu yang mempunyai diameter batang $15.7 \mathrm{~mm}$. Terdapat 93 galur yang memiliki diameter batang lebih besar dari tetua numbu (Gambar 3). Di antara galur-galur tersebut galur F4.319 merupakan galur yang memiliki diameter batang terbesar yaitu $25.0 \mathrm{~mm}$. Diharapkan individu-individu populasi F4 yang memiliki diameter batang lebih besar dibanding kedua tetua dapat mengurangi resiko rebah batang pada tanaman sorgum.

Karakter diameter batang merupakan karakter yang perlu diperhatikan dalam program pemuliaan tanaman karena karakter ini merupakan salah satu karakter yang mempengaruhi rebah batang dan potensi hasil pada sorgum. Menurut hasil penelitian Sugianto et al. (2015); Okiyo et al. (2010) diameter batang yang kecil memiliki resiko kerebahan yang tinggi dan dapat menurunkan hasil karena hasil fotosintat yang dihasilkan oleh daun tidak dapat mengalir secara optimal ke malai sorgum. Berdasarkan hal tersebut individu-individu yang memiliki diameter batang yang besar disamping lebih tahan terhadap kerebahan juga secara tidak langsung dapat meningkatkan potensi hasil

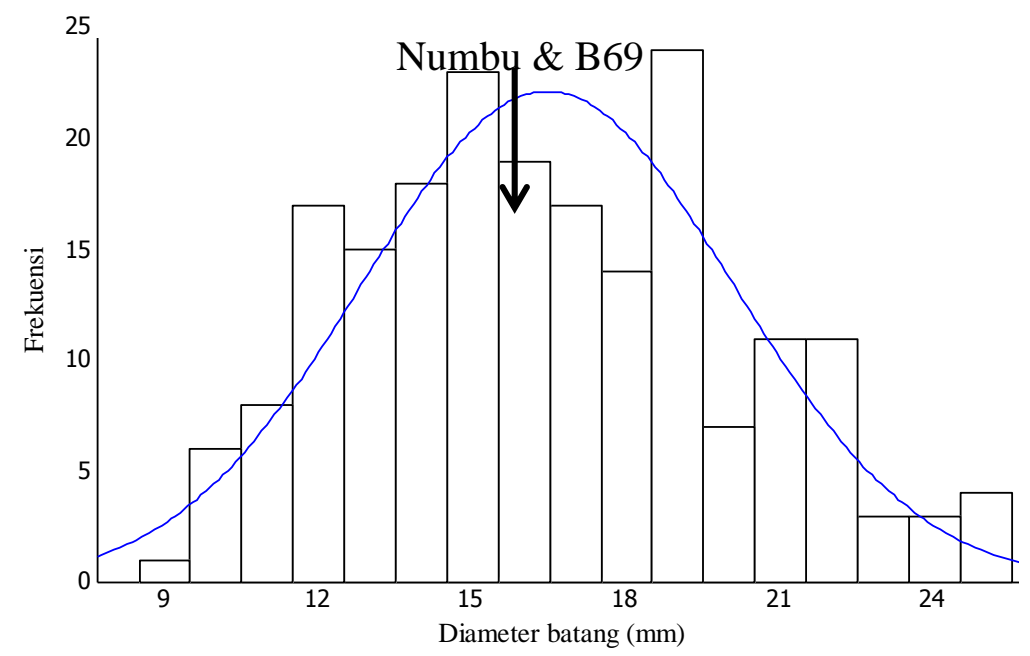

Gambar 3 Sebaran karakter diameter batang populasi F4 sorgum 
Karakter tinggi tanaman dalam program pemuliaan tanaman sangat penting dalam karakterisasi untuk pembentukan suatu varietas. Karakter ini mudah diturunkan, mudah diamati, dan dapat terekspresi pada seluruh lingkungan. Tinggi tanaman merupakan karakter yang berkaitan dengan produktivitas biji dan bioetanol. Tanaman yang tinggi pada peningkatan produktivitas tidak diperlukan karena tanaman yang tinggi dapat meningkatkan terjadinya resiko rebah batang (Aquaah 2007).

Nilai tengah tinggi tanaman populasi F4 sorgum adalah $224.7 \mathrm{~cm}$ dengan kisaran antara 123.0-300.0 cm. Berdasarkan informasi tersebut tinggi tanaman pada populasi F4 memiliki kisaran yang lebar. Hal ini menunjukkan bahwa pada populasi F4 sorgum yang diuji terdapat tinggi tanaman yang ekstrim, yaitu sangat rendah sebesar $123 \mathrm{~cm}$ yang terdapat pada galur F4.133 dan sangat tinggi sebesar $300 \mathrm{~cm}$ yang terdapat pada galur F4.121.

Berdasarkan penelitian ini terdapat 166 galur yang memiliki tinggi tanaman yang lebih rendah dan 24 galur yang memiliki tinggi tanaman lebih tinggi dibandingkan tetua Numbu, hanya 11 galur yang memiliki tinggi tanaman lebih rendah dibandingkan kedua tetua (Gambar 4). Hal ini sesuai dengan penelitian Puspitasari (2011) bahwa populasi F4 (UPCA.S1 x Numbu) sebagian besar memiliki tinggi tanaman lebih rendah dari numbu dan hanya beberapa galur yang lebih rendah dibandingkan tetua UPCA. Hal ini diduga karena kontribusi gen yang mengatur karakter tinggi tanaman pada tetua Numbu lebih besar pengaruhnya pada populasi $\mathrm{F} 4$ dibandingkan gen yang mengatur tinggi tanaman pada tetua B69.

Menurut Sungkono (2010) petani menempatkan tingkat kerebahan batang sebagai seleksi pertama sehingga petani tidak akan menanam sorgum yang mudah rebah. Oleh karena itu tinggi tanaman yang rendah diharapkan dapat meminimalisir terjadinya resiko rebah batang. Keuntungan lain dari tinggi tanaman yang rendah adalah dapat ditanam dengan populasi yang lebih rapat, lebih mudah dalam pemanenan serta pemeliharaan terhadap serangan burung dan serangan hama maupun penyakit.

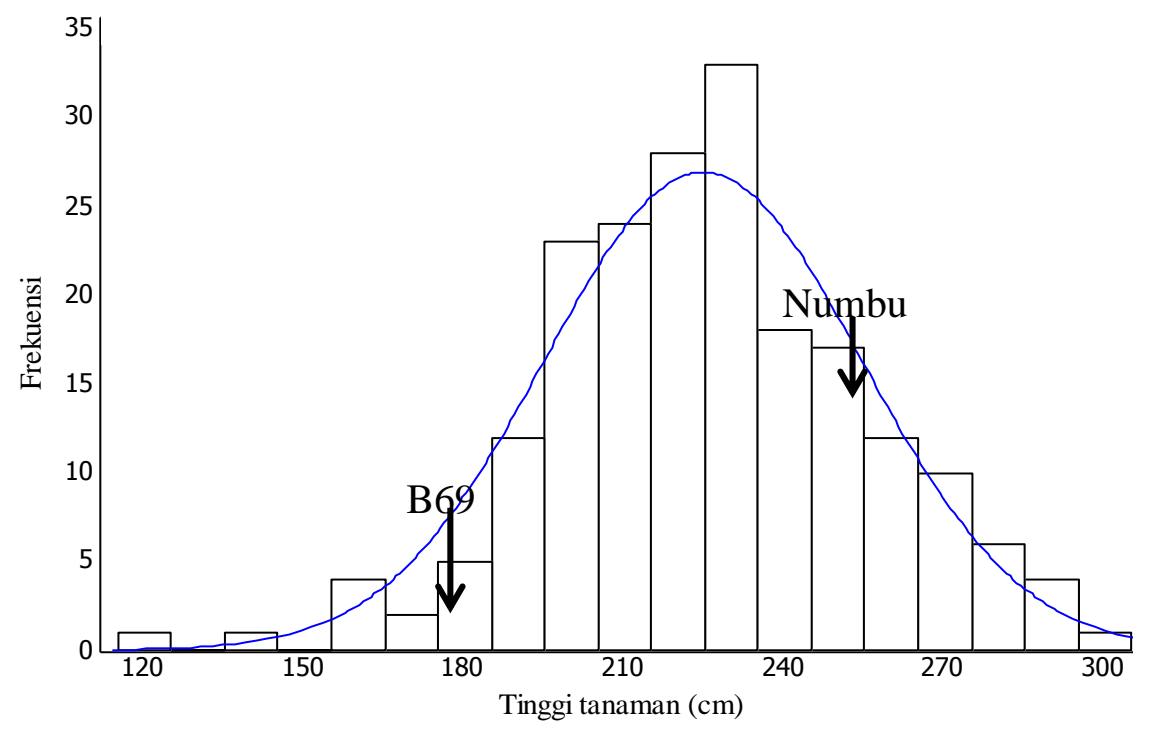

Gambar 4 Sebaran karakter tinggi tanaman populasi F4 sorgum 
Daun adalah organ utama fotosintesis pada tanaman yang menghasilkan fotosintat sebagai sumber energi. Dengan mengabaikan ukuran daun lainnya, semakin banyak jumlah daun maka akumulasi fotosintat yang dihasilkan akan semakin banyak ke biji (House 1985). Menurut Sungkono (2010) para pemulia tanaman banyak mengekploitasi karakter daun yang meliputi jumlah dan bentuk daun untuk meningkatkan produktivitas tanaman.

Berdasarkan rataan dan kisaran karakter agronomi galur-galur F5 sorgum, jumlah daun populasi F4 rata-rata 10 helai dengan kisaran yaitu antara 7-12 helai (Tabel 3). Kondisi ini normal seperti yang dikemukakan oleh House (1985), bahwa jumlah daun sorgum yang beradaptasi baik dengan lingkungannya berkisar antara 6-12 helai dengan periode munculnya daun lima hari per daun. Berdasarkan hal tersebut rata-rata genotipe sorgum yang diuji butuh waktu sekitar dua bulan untuk membentuk daun secara sempurna. Sebaran karakter jumlah daun menunjukan terdapat 49 galur yang memiliki jumlah daun lebih banyak dari kedua tetua (Gambar 5). Galur F4.112, F4.149, F4.30, F4.26, F4.202, F4.110, F4.301, F4.152 merupakan galur yang memiliki jumlah daun paling banyak yakni 12 helai. Menurut House (1985) sorgum yang mempunyai jumlah daun yang banyak berpotensi menghasilkan biji dengan produktivitas tinggi karena mempunyai organ fotosintesis yang banyak.

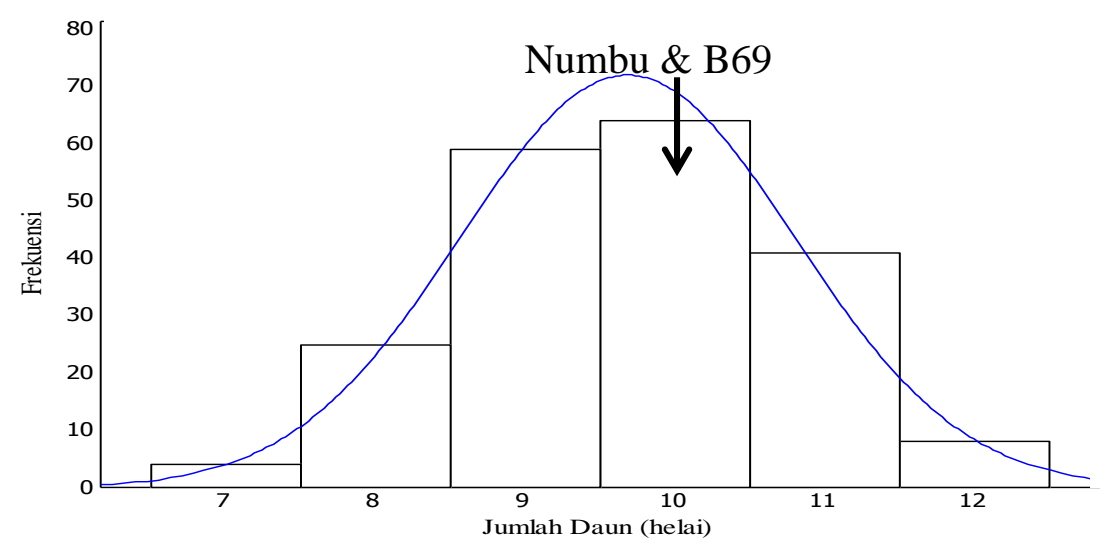

Gambar 5 Sebaran karakter jumlah daun populasi F4 sorgum

Panjang malai adalah komponen penting pada sorgum yang menghasilkan biji karena malai merupakan ruang tempat biji sorgum tumbuh dan berkembang. Menurut Poehlman dan Sleper (2006) hasil yang tinggi pada sorgum berkorelasi terhadap ukuran panjang malai. Hal ini mengindikasikan semakin panjang malai sorgum maka jumlah biji akan meningkat yang akan diikuti dengan peningkatan bobot biji malai ${ }^{-1}$ (House 1985).

Panjang malai populasi F4 sorgum rata-rata $21.2 \mathrm{~cm}$ dengan kisaran antara 12.0-29.0 cm. Hal ini menunjukkan bahwa panjang malai galur $\mathrm{F} 4$ yang diuji umumnya lebih pendek dari panjang malai tetua B69 yang mencapai $22.6 \mathrm{~cm}$ (Tabel 3). Namun demikian berdasarkan sebaran karakter panjang malai populasi F4 terdapat 61 galur yang memiliki panjang malai melebihi nilai tengah kedua tetua (Gambar 6). Galur F4.237 merupakan galur yang memiliki panjang malai paling tinggi yaitu $29 \mathrm{~cm}$. Galur-galur yang lebih tinggi panjang malainya dibanding kedua tetua sangat potensial sebagai galur dengan produktivitas biji tinggi, karena mempunyai kapasitas penampungan hasil yaitu malai yang panjang sehingga mampu menampung biji dalam jumlah yang banyak. 


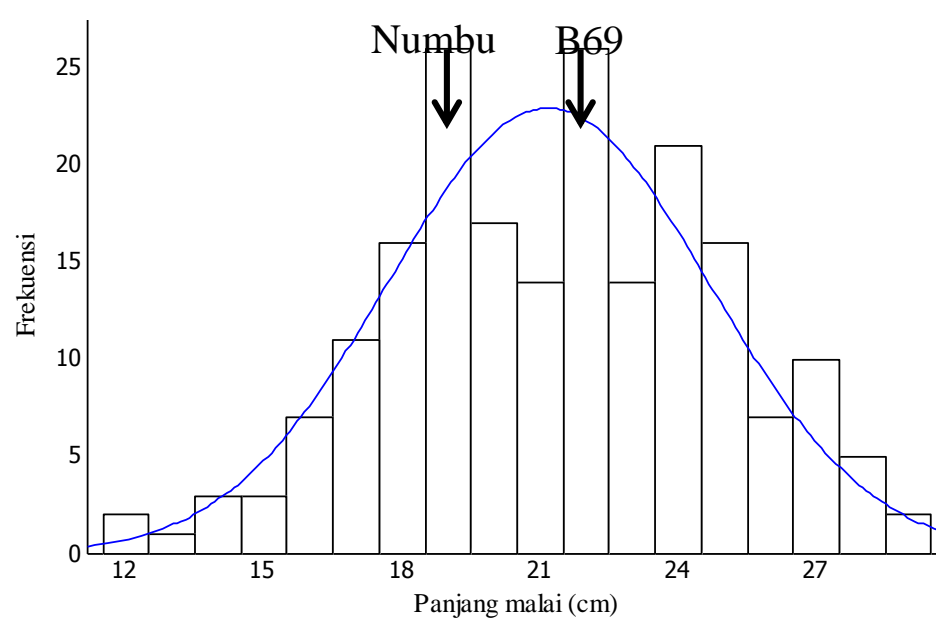

Gambar 6 Sebaran karakter panjang malai populasi F4 sorgum

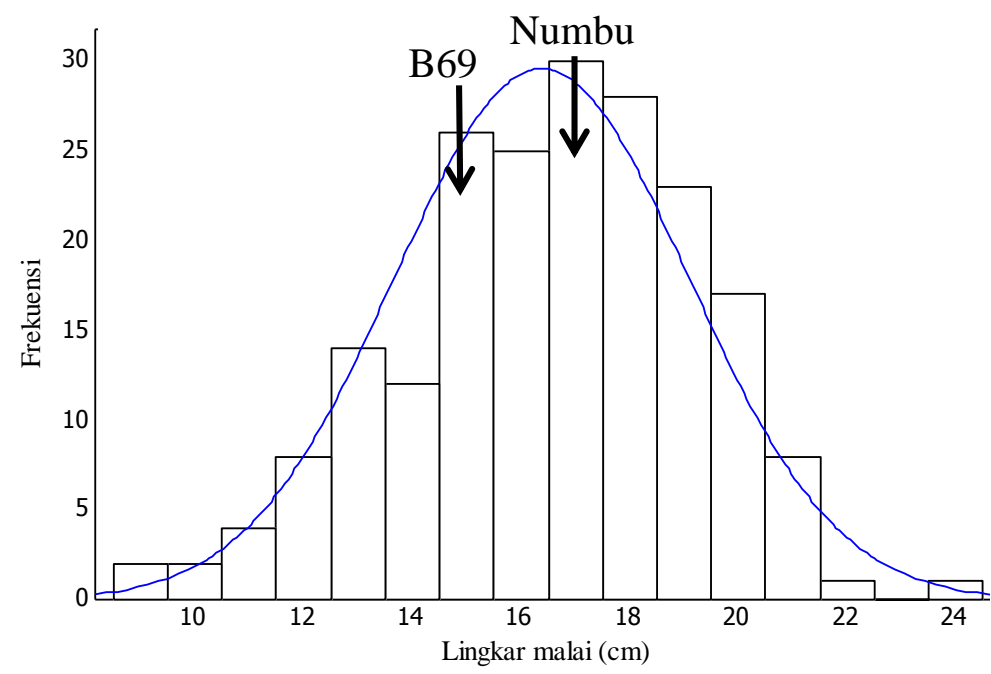

Gambar 7 Sebaran karakter lingkar malai populasi F4 sorgum

Lingkar malai populasi F4 sorgum rata-rata $16.4 \mathrm{~cm}$ dengan kisaran antara 9-24 cm. Hal ini menunjukkan bahwa lingkar malai galur F4 yang diuji umumnya hampir sama dengan lingkar malai tetua Numbu yang mencapai $16.7 \mathrm{~cm}$ (Tabel 3). Berdasarkan sebaran karakter bobot malai populasi F4 terdapat 78 galur yang memiliki lingkar malai melebihi nilai tengah kedua tetua (Gambar 7). Galur F4.110 merupakan galur yang memiliki lingkar malai paling lebar $24 \mathrm{~cm}$.

Berdasarkan penelitian ini lingkar malai yang lebar dapat mencerminkan bobot biji malai ${ }^{-1}$ yang tinggi. Hal ini diduga karena adanya korelasi yang kuat, positif dan nyata antara bobot biji malai ${ }^{-1}$ dimana semakin besar lingkar malai maka mengindikasikan semakin banyak jumlah biji yang tumbuh pada malai yang menyebabkan bobot biji malai ${ }^{-1}$ menjadi tinggi. Hal ini dibuktikan pada galur F4.110 dimana memiliki lingkar malai yang terlebar namun memiliki bobot biji malai $^{-1}(126.7 \mathrm{gr})$ tergolong tinggi. Hal ini memberi gambaran bahwa secara umum galur-galur yang lebih besar lingkar malainya pada penelitian ini memiliki bobot biji malai ${ }^{-1}$ yang tinggi. 
Bobot malai merupakan hasil akumulasi antara bobot malai ditambah dengan bobot biji yang terdapat di malai. Bobot malai ini dipengaruhi oleh jumlah biji, berat biji, ukuran biji, panjang malai, dan diameter malai (House 1985). Nilai tengah karakter bobot malai pada populasi F4 sorgum yang diuji berada di antara nilai tengah kedua tetua dengan kisaran nilai 8.7 -157.5 gram. Nilai tengah karakter bobot malai masih lebih rendah dibandingkan tetua Numbu, namun selisih nilai tengahnya tidak berbeda jauh dan hanya terpaut 4.7 gram. Sebaran karakter bobot malai populasi F4 sorgum menunjukkan terdapat 80 galur yang memiliki bobot malai lebih besar dibandingkan kedua tetua (Gambar 8). Galur F4.172 merupakan galur yang memiliki bobot malai paling besar yaitu 157.5 gram.

Pengamatan pada bobot malai merupakan karakter yang sangat penting untuk mengetahui kemampuan setiap genotipe tanaman sorgum mempertahankan potensi hasil (Dermawan 2011). Adanya korelasi yang tinggi antara bobot malai dan bobot biji malai ${ }^{-1}$ pada penelitian ini menyebabkan karakter ini merupakan gambaran langsung dari bobot biji malai ${ }^{-1}$ artinya semakin tinggi bobot malai maka bobot biji malai ${ }^{-1}$ pasti akan semakin tinggi. Hasil penelitian Din et al. (2012) menunjukkan bahwa karakter bobot malai berkolerasi positif dan sangat nyata dengan karakter bobot biji malai ${ }^{-1}(\mathrm{r}=0.92 * *)$. Hal ini mengindikasikan bahwa hasil biji yang tinggi diperoleh dari bobot malai yang lebih besar dan berat.

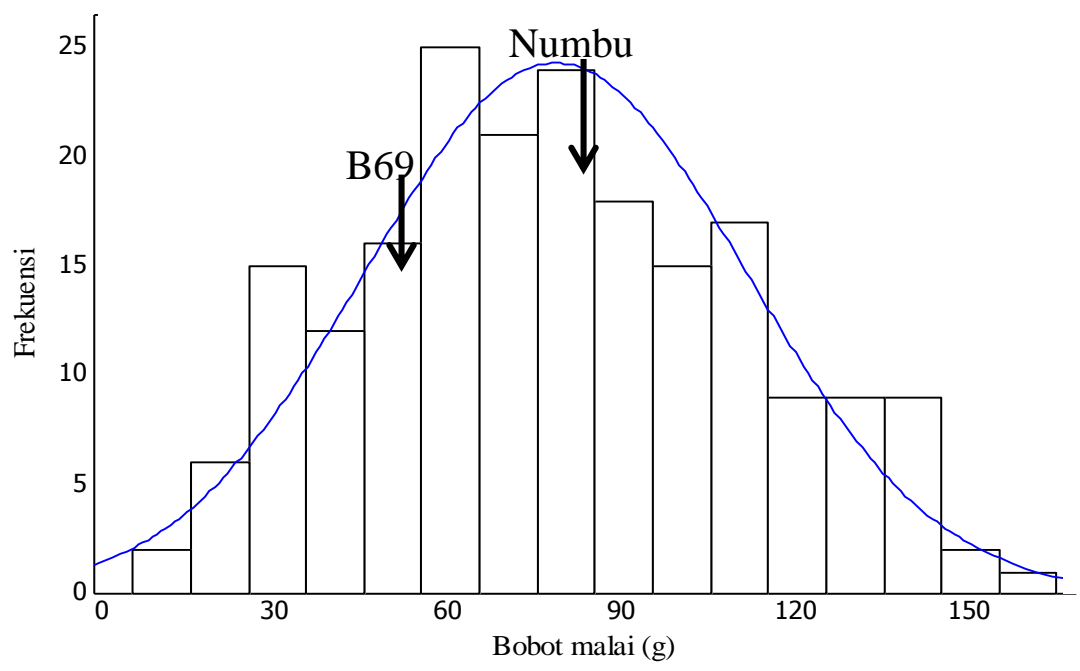

Gambar 8 Sebaran karakter bobot malai populasi F4 sorgum

Karakter bobot seribu biji merupakan ukuran yang menggambarkan besar kecilnya biji yang dihasilkan oleh tanaman serealia. Biji yang berukuran besar ditunjukkan dengan bobot biji yang berat dan umumnya dimanfaatkan sebagai sumber bahan pangan karena kulit bijinya lebih mudah dirontokan (Aquaah 2007). Keragaan bobot seribu biji populasi F4 sorgum rata-rata 30.3 gram dengan kisaran 16.7 - 41.5 gram (Tabel 3). Berdasarkan nilai tengah bobot seribu biji maka galur F4 yang diuji lebih rendah dibandingkan bobot seribu biji biji varietas Numbu, namun dari sebaran karakter bobot seribu biji terdapat 15 galur F4 yang mempunyai keragaan bobot seribu biji lebih tinggi dari kedua tetua (Gambar 9). Galur F4.210 merupakan galur yang memiliki bobot seribu biji paling besar yakni 41.5 gram. Galur yang lebih besar dari kedua tetua sangat potensial dikembangkan sebagai varietas sorgum sebagai sumber bahan pangan dengan hasil biji tinggi. 


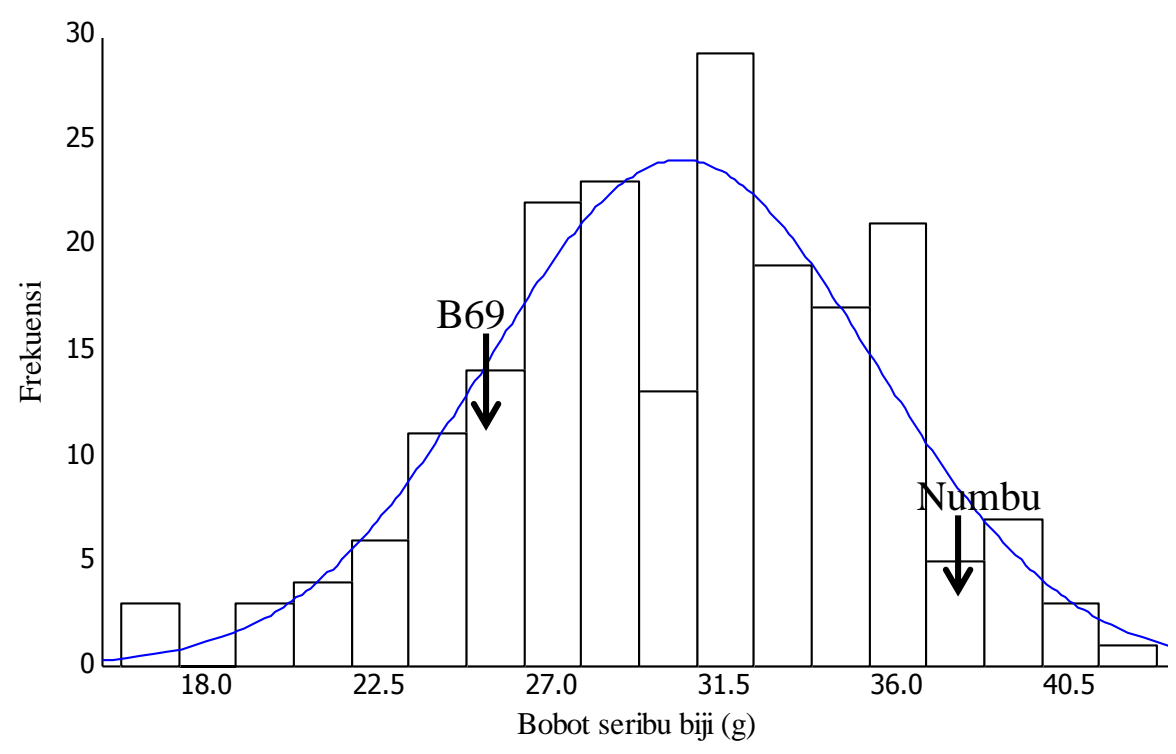

Gambar 9 Sebaran karakter bobot seribu biji populasi F4 sorgum

Bobot biji malai ${ }^{-1}$ merupakan potensi hasil bersih tanaman sorgum. Bobot biji malai ${ }^{-1}$ merupakan hasil per individu tanaman sehingga menjadi karakter yang sangat penting dalam penentuan hasil biji (Sungkono et al. 2009). Rata-rata karakter bobot biji malai ${ }^{-1}$ populasi $\mathrm{F} 4$ sorgum yang diuji berada di antara nilai tengah kedua tetua dengan kisaran nilai tengah 6.3 -139.6 gram . Nilai tengah karakter bobot biji malai ${ }^{-1}$ galur masih lebih rendah dibandingkan tetua Numbu, namun selisih nilai tengahnya tidak berbeda jauh dan hanya terpaut 6.5 gram. Berdasarkan sebaran karakter bobot biji malai ${ }^{-1}$ populasi $\mathrm{F} 4$ menunjukkan terdapat 79 galur yang memiliki bobot biji malai ${ }^{-1}$ lebih besar dibandingkan kedua tetua (Gambar 10). Galur F4.172 merupakan galur yang memiliki bobot biji malai ${ }^{-1}$ paling besar yaitu 139.6 gram.

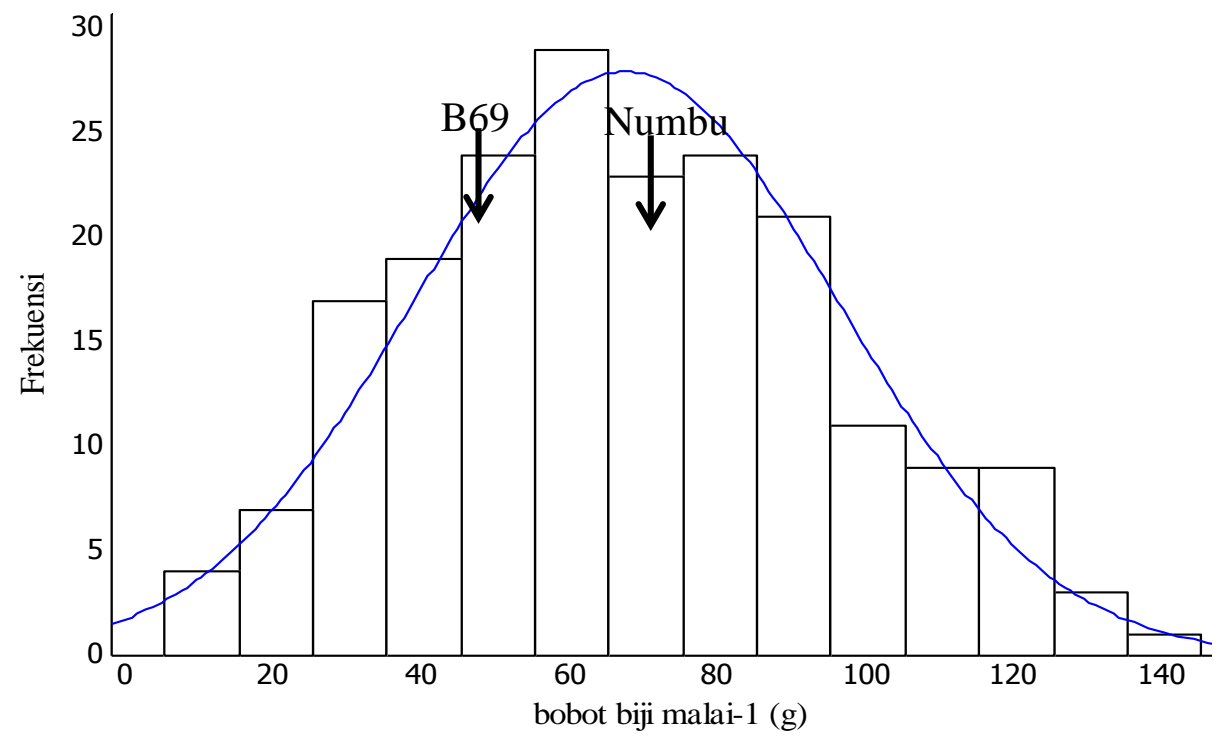

Gambar 10 Sebaran karakter bobot biji malai ${ }^{-1}$ populasi F4 sorgum 
Nilai tengah karakter bobot biji malai ${ }^{-1}$ pada populasi F4 mengalami peningkatan dibandingkan nilai tengah populasi F2 yang dilakukan Sulistyowati (2015). Peningkatan nilai tengah terjadi diduga karena pertanaman dilakukan pada musim tanam yang berbeda yaitu terdapat perbedaan temperatur dan curah hujan yang berbeda (Lampiran 2). Hal ini menunjukkan bahwa lingkungan berperan untuk meningkatkan nilai tengah seluruh karakter agronomi yang diamati. Peningkatan nilai tengah untuk karakter agronomi yang diamati pada populasi F4 juga diduga karena pada populasi F4 telah lebih banyak terfiksasi gen-gen aditif dan pengaruh epistasis komplementer atau duplikat telah semakin berkurang. Hal ini terlihat bahwa populasi F4 memiliki nilai heritabilitas tergolong tinggi untuk semua karakter yang diamati. Peningkatan nilai tengah bobot biji pada penelitian ini memberikan peluang untuk mendapatkan galur sorgum berdaya hasil tinggi melalui metode penggaluran single seed descent.

\section{Pendugaan Aksi Gen Yang Mengendalikan KarakterAgronomi Berdasarkan Sebaran Populasi F4}

Karakter-karakter agronomi seperti karakter hasil merupakan karakter kuantitatif yang dikendalikan oleh banyak gen yang bersifat aditif dan fenotipenya tidak dapat diklasifikasikan secara jelas karena mengikuti sebaran yang kontinyu. Kemenjuluran kurva (Skewness) dan keruncingan kurva (Kurtosis) dapat digunakan untuk menjelaskan karakteristik kurva kontinyu sehingga dari nilainilai tersebut dapat diduga aksi gen dan jumlah gen yang mengendalikan suatu karakter pada populasi bersegregasi. Pendugaan aksi gen dan jumlah gen yang terlibat dapat diduga dari pola sebaran pada suatu populasi (Roy 2000).

Pendugaan aksi gen biasanya dilakukan pada populasi F2 dimana segregasi maksimum terjadi. Populasi F2 setiap genotipe diwakili oleh satu individu tanaman sampai generasi F4 dengan metode penggaluran single seed descent sehingga keragaman genetik yang luas pada populasi F2 dapat dipertahankan sampai populasi F4 (Roy 2000). Hal ini sesuai dengan penelitian Sulistyowati (2015) bahwa seluruh karakter agronomi yang diamati pada populasi F2 memiliki keragaman genetik yang tergolong sedang sampai luas sementara populasi F4 hasil single seed descent pada penelitian ini juga memiliki keragaman genetik yang sedang sampai luas sehingga pada populasi $\mathrm{F} 4$ hasil penggaluran dengan metode single seed descent pendugaan aksi gen masih dapat dilakukan.

Analisis pola sebaran pada karakter agronomi yang diamati terdapat pada Gambar 3 sampai 10 serta nilai skewness dan kurtosis yang diamati ditampilkan pada Tabel 4 dan Tabel 5. Berdasarkan hasil uji Z skewness dan uji Z kurtosis untuk seluruh karakter agronomi yang diamati tidak berbeda nyata. Hal ini menunjukkan bahwa karakter agronomi memiliki pola sebaran tergolong normal bersifat poligenik dengan aksi gen aditif, artinya pengaruh total gen minor lebih besar dari pengaruh lingkungan tetapi pengaruh per satuan gen lebih kecil dari pengaruh lingkungan. Hal ini sesuai dengan penelitian Puspitasari (2011) dimana populasi F4 hasil persilangan UPCA dan Numbu karakter panjang malai, diameter batang dan tinggi tanaman memiliki aksi gen aditif. Aksi gen aditif yang mengendalikan suatu karakter mengindikasikan bahwa alel tersebut hasil kontribusi genetik diantara kedua tetua dan alel-alel tetua akan diwariskan dari tetua kepada turunannya (Griffiths et al. 2005). 
Menurut Samak et al. (2011) karakter yang memiliki sebaran normal disebabkan keterlibatan gen-gen aditif yang lebih besar dalam mengendalikan keragaman dibandingkan pengaruh lingkungan. Hal ini sesuai dengan pendugaan aksi gen yang dilakukan dimana seluruh karakter agronomi dikendalikan oleh aksi gen aditif (Tabel 4). Sebaran data normal ini sangat efektif terhadap proses seleksi pada generasi berikutnya (Bari 1998).

Penelitian ini menunjukan tidak terdapat pengaruh aksi gen epistatis dan dominan terhadap semua karakter agronomi yang diamati. Hal ini sesuai dengan penelitian Sulistyowati (2015) bahwa generasi F2 hasil persilangan B69 dan Numbu memiliki memiliki pola sebaran normal dan dikendalikan banyak gen dengan aksi gen aditif pada karakter tinggi tanaman, diameter batang, panjang malai, bobot malai, dan bobot biji malai ${ }^{-1}$. Kesamaan aksi gen generasi F2 dan F4 pada karakter tersebut menunjukan bahwa karakter tersebut dikendalikan oleh gen-gen bebas tanpa adanya pengaruh interaksi gen ataupun lingkungan .

Pada populasi F4 yang diuji seluruh karakter pada tanaman sorgum secara konsisten diduga dikendalikan banyak gen / poligenik dengan aksi gen aditif. Nilai fenotipe segregan-segregan potensial yang lebih baik dibanding tetuanya disebabkan oleh gen-gen aditif yang bersifat poligenik. Seleksi pada karakter yang bersifat poligenik akan efektif jika dilakukan pada generasi lanjut. Menurut Chahal dan Gosal (2003) pada metode SSD seleksi di generasi lanjut dapat dilakukan pada populasi F5 atau F6. Seleksi pada generasi lanjut dilakukan karena pada generasi lanjut gen-gen aditif telah terfiksasi dengan baik, sehingga pada generasi lanjut proporsi homozigositas yang menyusun karakter yang bersifat poligenik telah tinggi (Riaz \& Chowdhry 2003; Santoso 2007).

Tabel 4 Aksi gen karakter agronomi populasi F4 (B69 x Numbu) sorgum

\begin{tabular}{|c|c|c|c|c|}
\hline Karakter & Skewness & SE Skewness & Uji Z Skewness & Aksi Gen \\
\hline Tinggi tanaman & -0.14 & 0.17 & $-0.81^{\mathrm{tn}}$ & Aditif \\
\hline Diameter batang & 0.23 & 0.17 & $1.34^{\mathrm{tn}}$ & Aditif \\
\hline Jumlah daun & -0.07 & 0.17 & $-0.41^{\mathrm{tn}}$ & Aditif \\
\hline Panjang malai & -0.10 & 0.17 & $-0.60^{\operatorname{tn}}$ & Aditif \\
\hline Lingkar malai & -0.34 & 0.17 & $-1.95^{\mathrm{tn}}$ & Aditif \\
\hline Bobot seribu biji & -0.25 & 0.17 & $-1.46^{\mathrm{tn}}$ & Aditif \\
\hline Bobot malai & 0.18 & 0.17 & $1.07^{\mathrm{tn}}$ & Aditif \\
\hline Bobot biji malai $^{-1}$ & 0.19 & 0.17 & $1.08^{\mathrm{tn}}$ & Aditif \\
\hline
\end{tabular}

Tabel 5 Jumlah gen karakter agronomi populasi F4 (B69 x Numbu) sorgum

\begin{tabular}{lrccc}
\hline Karakter & Kurtosis & SE Kurtosis & Uji Z Kurtosis & Jumlah gen \\
\hline Tinggi tanaman & -0.44 & 0.34 & $-1.29^{\text {tn }}$ & Banyak \\
Diameter batang & -0.64 & 0.34 & $-1.88^{\text {tn }}$ & Banyak \\
Jumlah daun & -0.44 & 0.34 & $-1.29^{\text {tn }}$ & Banyak \\
Panjang malai & -0.39 & 0.34 & $-1.14^{\text {tn }}$ & Banyak \\
Lingkar malai & -0.08 & 0.34 & $-0.22^{\text {tn }}$ & Banyak \\
Bobot seribu biji & -0.21 & 0.34 & $-0.61^{\text {tn }}$ & Banyak \\
Bobot malai & -0.60 & 0.34 & $-1.76^{\text {tn }}$ & Banyak \\
Bobot biji malai $^{-1}$ & -0.58 & 0.34 & $-1.69^{\text {tn }}$ & Banyak \\
\hline
\end{tabular}

Keterangan: $\mathrm{SE}=$ Standard Eror, $\mathrm{tn}=$ tidak nyata 


\section{Pendugaan Komponen Ragam dan Nilai Heritabilitas Karakter Agronomi}

Ketersediaan materi genetik yang beragam sangat diperlukan dalam kegiatan seleksi. Keberhasilan seleksi sangat ditentukan oleh adanya keragaman yang disebabkan oleh faktor genetik (Roy 2000). Besarnya pengaruh faktor genetik terhadap suatu karakter dapat dilihat dari nilai heritabilitas. pendugaan nilai heritabilitas penting dilakukan karena nilai ini dapat dijadikan sebagai tolak ukur untuk menentukan peluang diturunkannya suatu karakter kepada generasi selanjutnya. Semakin besar nilai heritabilitas maka proporsi ragam genetik lebih besar dibandingkan ragam lingkungannya.

Nilai duga heritabilitas arti luas disajikan pada Tabel 6. Seluruh karakter yang diamati pada populasi F4 memiliki nilai heritabilitas yang tergolong tinggi. Nilai duga heritabilitas arti luas yang tinggi pada karakter agronomi yang diamati mengindikasikan bahwa pewarisan karakter tersebut ditentukan oleh ragam genetik yang besar dengan sedikit pengaruh ragam lingkungan. Hal tersebut ditunjukan dengan koefisien keragaman genetik pada karakter agronomi yang diamati tergolong sedang sampai luas. Menurut Kuswanto (2006) karakter yang memiliki nilai heritabilitas yang tinggi dan berasal dari luasnya perbedaan genetik antara kedua tetua maka keragaman genetik pada suatu populasi akan tetap tinggi. Hal ini yang menyebabkan heritabilitas karakter agronomi populasi F4 tetap tinggi seperti populasi awal yang dilakukan Sulistyowati (2015).

Koefisien keragaman genetik (KKG) menggambarkan seberapa luas suatu karakter memiliki keragaman genetik. Karakter agronomi yang diamati pada galur F4 memiliki keragaman genetik yang sedang dan luas. Karakter bobot biji malai ${ }^{-1}$ merupakan karakter hasil yang memiliki nilai koefisien keragaman genetik yang tinggi dibandingkan karakter lainnya. Hal ini sesuai dengan penelitian Sihaloho (2015) dimana individu-individu tanaman kedelai hasil single seed descent pada populasi F4 juga memiliki keragaman genetik yang luas pada karakter bobot biji. Menurut Haq (2008) apabila suatu karakter memiliki keragaman genetik yang luas maka individu dalam populasi tersebut relatif beragam. Berdasarkan hal tersebut pada populasi F4 sorgum hasil penggaluran dengan metode single seed descent terdapat individu tanaman yang sangat beragam terutama pada karkter bobot biji malai $^{-1}$, artinya terdapat potensi untuk menghasilkan galur sorgum berdaya hasil tinggi pada populasi $\mathrm{F} 4$ hasil metode penggaluran single seed descent.

Tabel 6 Nilai komponen ragam dan koefisien keragaman genetik (KKG) karakter agronomi pada populasi $\mathrm{F} 4$ sorgum

\begin{tabular}{|c|c|c|c|c|c|}
\hline Karakter & $\left(\sigma_{e}^{2}\right)$ & $\left(\sigma_{g}^{2}\right)$ & $\left(\sigma_{p}^{2}\right)$ & KKG $(\%)$ & $\mathrm{H}_{\mathrm{bs}}^{2}(\%)$ \\
\hline Diameter batang & 2.2 & 11.0 & 13.1 & $20.1^{\mathrm{L}}$ & $84.0^{\mathrm{T}}$ \\
\hline Tinggi tanaman & 87.1 & 799.4 & 886.5 & $12.6^{\mathrm{S}}$ & $90.0^{\mathrm{T}}$ \\
\hline Jumlah daun & 0.3 & 0.9 & 1.2 & $10.4^{\mathrm{S}}$ & $74.0^{\mathrm{T}}$ \\
\hline Panjang malai & 2.3 & 9.9 & 12.2 & $14.9^{\mathrm{S}}$ & $81.0^{\mathrm{T}}$ \\
\hline Lingkar malai & 1.2 & 6.2 & 7.3 & $15.2^{\mathrm{S}}$ & $84.0^{\mathrm{T}}$ \\
\hline Bobot seribu biji & 5.3 & 19.9 & 25.1 & $14.7^{\mathrm{S}}$ & $79.0^{\mathrm{T}}$ \\
\hline Bobot malai & 117.3 & 971.9 & 1089.2 & $39.9^{\mathrm{L}}$ & $89.0^{\mathrm{T}}$ \\
\hline Bobot biji malai $^{-1}$ & 77.7 & 743.2 & 820.9 & $40.6^{\mathrm{L}}$ & $91.0^{\mathrm{T}}$ \\
\hline
\end{tabular}




\section{Analisis Korelasi Antar Karakter Agronomi Galur-Galur F4 Sorgum}

Analisis korelasi antar karakter menggambarkan hubungan antara dua karakter sehingga dapat dimanfaatkan untuk mendapatkan informasi mengenai hubungan antara karakter yang diamati dengan karakter target. Menurut Mattjik dan Sumertajaya (2006) nilai korelasi berada di antara -1 dan +1 dengan nilai ekstrim menunjukkan hubungan linear yang sempurna dan nilai tengah nol menunjukkan tidak ada hubungan antara kedua karakter. Menurut Sungkono (2010) bobot biji malai ${ }^{-1}$ merupakan karakter yang menggambarkan daya hasil. Oleh sebab itu informasi untuk mengetahui keeratan hubungan karakter agronomi yang diamati terhadap karakter bobot biji malai ${ }^{-1}$ menjadi sangat penting.

Tabel 7 Koefisien korelasi karakter agronomi populasi F4 hasil persilangan B69 x Numbu sorgum

\begin{tabular}{lccccccc}
\hline Karakter & TT & JD & PM & LM & BM & BSB & BBM \\
\hline DB & 0.05 & $0.36^{* *}$ & $0.36^{* *}$ & $0.60^{* *}$ & $0.65^{* *}$ & 0.07 & $0.64^{* *}$ \\
TT & & $0.45^{* *}$ & $0.27^{* *}$ & $0.18^{*}$ & $0.34^{* *}$ & $0.44^{* *}$ & $0.35^{* *}$ \\
JD & & & -0.01 & $0.33^{* *}$ & $0.33^{* *}$ & $0.14^{*}$ & $0.33^{* *}$ \\
PM & & & & $0.27^{* *}$ & $0.47^{* *}$ & $0.28^{* *}$ & $0.47^{* *}$ \\
LM & & & & & $0.80^{* *}$ & 0.10 & $0.79^{* *}$ \\
BM & & & & & & $0.29 * *$ & $0.99^{* *}$ \\
BSB & & & & & & & $0.32^{* *}$ \\
BBM & & & & & & &
\end{tabular}

Keterangan: $*=$ berkorelasi nyata pada taraf $\alpha=0.05, * *=$ berkorelasi nyata pada taraf $\alpha=0.01$, $\mathrm{DB}=$ diameter batang, $\mathrm{TT}=$ tinggi tanaman, JD = jumlah daun, $\mathrm{PM}=$ panjang malai, $\mathrm{LM}=$ lingkar malai, $\mathrm{BM}=$ bobot malai, $\mathrm{BSB}=$ bobot seribu biji, dan $\mathrm{BBM}=$ bobot biji malai ${ }^{-1}$.

Analisis korelasi antara karakter agronomi yang diamati ditampilkan pada Tabel 6. Tinggi tanaman tidak berkorelasi nyata dengan diameter batang. Hal ini mengindikasikan pada populasi F4 peningkatan tinggi tanaman tidak diikuti oleh peningkatan diameter batang. Diameter batang yang besar sangat dibutuhkan untuk menopang tinggi tanaman agar tidak mudah rebah dan meningkatkan potensi hasil tanaman sorgum.

Tinggi tanaman berkorelasi positif dan nyata dengan jumlah daun. Artinya peningkatan tinggi tanaman akan diikuti oleh peningkatan jumlah daun. Hal ini sesuai dengan penelitian Puspitasari et al. (2012); Jain dan Patel (2014) dimana tinggi tanaman berkorelasi positif dan nyata terhadap jumlah daun. Hal ini disebabkan karena peningkatan proses fotosintesis akibat meningkatnya proporsi jumlah daun akan diikuti dengan peningkatan aktivitas sel dalam melakukan pembelahan, pembesaran dan pemanjangan. Peningkatan aktivitas pada level sel inilah yang mengakibatkan tinggi tanaman menjadi meningkat (House 1985).

Karakter tinggi tanaman berkorelasi positif dan nyata dengan bobot biji malai $^{-1}$. Hal ini menunjukkan bahwa semakin tinggi tanaman maka daya hasil yang diperoleh akan semakin tinggi. Hal ini mengindikasikan tidak terdapat individu-individu tanaman F4 yang memiliki kombinasi sifat yang diinginkan pemulia yaitu galur yang memiliki nilai tengah tinggi tanaman rendah tetapi nilai tengah bobot biji malai ${ }^{-1}$ tinggi dibanding kedua tetua. Perlu pengembangan lebih 
lanjut agar diperoleh galur dengan karakter tinggi tanaman yang rendah dan bobot biji malai ${ }^{-1}$ yang lebih tinggi dibandingkan kedua tetua. Hal ini juga sesuai dengan penelitian Yazdani (2012); Kenga et al. (2006); Mallinath et al. (2004) dimana tinggi tanaman berkorelasi positif dan nyata dengan bobot biji malai ${ }^{-1}$.

Diameter batang berkorelasi positif dan nyata dengan bobot biji malai ${ }^{-1}$. Hal ini menunjukkan bahwa peningkatan diameter batang akan diikuti oleh peningkatan bobot biji malai ${ }^{-1}$. Menurut Aquaah (2007) diameter yang besar menyebabkan fotosintat yang dihasilkan daun dapat mengalir secara optimal ke bagian malai sorgum sehingga bobot biji sorgum menjadi meningkat.

Korelasi terlihat antar komponen hasil meliputi panjang malai, bobot malai, lingkar malai, bobot biji malai ${ }^{-1}$ dan bobot seribu biji. Panjang malai merupakan ruang tempat biji tumbuh dan berkembang. Panjang malai berkorelasi postif dan sangat nyata dengan lingkar malai, bobot seribu biji, bobot biji malai ${ }^{-1}$ dan bobot malai. Hubungan ini menunjukkan semakin panjang malai sorgum maka karakter lingkar malai, bobot seribu biji, bobot malai, dan bobot biji malai ${ }^{-1}$ juga meningkat. Hal ini juga sesuai dengan penelitian Zongjian et al. (2010).

Karakter bobot malai memiliki nilai korelasi positif yang sangat kuat dengan bobot biji malai ${ }^{1}$. Hal ini sesuai dengan Poehlman dan Sleper (1996) yang menyatakan bobot biji malai ${ }^{-1}$ berkorelasi positif dengan ukuran malai dan bobot malai. Korelasi tersebut menunjukkan bahwa bobot malai memiliki hubungan yang sangat erat dengan karakter bobot biji malai ${ }^{-1}$ sehingga bobot malai dapat disebut sebagai karakter yang menggambarkan secara langsung peningkatan bobot biji malai ${ }^{-1}$.

\section{Simpulan}

Populasi sorgum F4 hasil metode penggaluran single seed descent dari persilangan B69 x Numbu menunjukkan keragaan karakter yang beragam. Seluruh karakter agronomi yang diamati memiliki heritabilitas yang tinggi. Karakter diameter batang, bobot malai dan bobot biji malai ${ }^{-1}$ memiliki keragaman genetik luas, sedangkan karakter lainnya memiliki keragaman genetik sedang. Berdasarkan nilai uji Z skewness dan uji Z kurtosis seluruh karakter agronomi yang diamati memiliki sebaran normal, bersifat poligenik, dan dipengaruhi oleh aksi gen aditif. Karakter diameter batang, lingkar malai, dan bobot malai memiliki korelasi yang positif, sangat nyata, dan kuat terhadap karakter bobot biji malai ${ }^{-1}$. 


\title{
4 PENDUGAAN PARAMETER GENETIK DAN SELEKSI RILs F5 SORGUM HASIL PENGGALURAN DENGAN METODE SINGLE SEED DESCENT
}

\author{
Estimation of Genetic Parameters and Selection Sorghum RILs F5 \\ Derived From Single Seed Descent
}

\begin{abstract}
The purpose of this study was to obtain information about the value of genetic parameters of agronomic characters of sorghum lines develop by single seed descent as information for selecting RILs F5 for high yield. The research was conducted from February to May 2014 in Bogor, West Java, Indonesia with an altitude of $\pm 240 \mathrm{~m}$ asl and a temperature of $27^{\circ} \mathrm{C}$. The genetic materials used consited of 201 RIL F5, national varieties Numbu, Samurai-1, and Samurai-2, and a mutant strain B69 as control. The experimental design used was augmented design. The results showed that the RILs F5 significantly different in the characters of plant height, leaf number, panicle length, circumference panicle, panicle weight, seed filling period and grain weight penicle $e^{-1}$. High broad sense heritability values and broad genetic diversity were observed in the character of the seed filling period, plant height, leaf number, panicle length, circumference panicle, panicle weight and grain weight penicle $e^{-1}$. There were RIL F5 which have higher yield than the two parents and are uniform with lower within line variance. Selection was conducted based on grain weight panicle ${ }^{-1}$ increased $35.3 \%$ yield but at the same time increased plant height by 5\%. Simultanous selection by grain weight panicle $e^{-1}$ and plant height increased yield by $21 \%$ and reduced plant height by $6.9 \%$. This gives the opportunity to obtain high yielding variety with shorter structure.
\end{abstract}

Key words : single seed descent, heritability, selection diferential

\begin{abstract}
Abstrak
Tujuan dari penelitian ini adalah untuk memperoleh informasi tentang nilai parameter genetik karakter agronomi galur sorgum hasil single seed descent sebagai informasi untuk menyeleksi RILs F5 berdaya hasil tinggi. Penelitian ini dilakukan dari bulan Juli sampai Oktober 2014 di Dramaga, Bogor dengan ketinggian $\pm 240 \mathrm{~m}$ dpl dan suhu $27^{\circ} \mathrm{C}$. Bahan genetik yang digunakan adalah 201 RIL F5, varietas nasional Numbu, Samurai-1, Samurai-2, dan galur mutan B69 sebagai kontrol. Rancangan percobaan yang digunakan adalah augmented. Hasil penelitian menunjukkan bahwa RILs F5 berbeda nyata pada karakter tinggi tanaman, jumlah daun, panjang malai, lingkar malai, berat malai, periode pengisian biji dan bobot biji malai ${ }^{-1}$. Nilai heritabilitas tinggi dan keragaman genetik yang luas terdapat pada karakter periode pengisian biji, tinggi tanaman, jumlah daun, panjang malai, lingkar malai, bobot malai, dan bobot biji malai ${ }^{-1}$. Terdapat RIL F5 yang memiliki ragam dalam galur lebih rendah dan memiliki daya hasil lebih baik dibanding kedua tetua. Seleksi berdasarkan bobot biji malai ${ }^{-1}$ meningkatkan hasil $35.3 \%$ namun tinggi tanaman meningkat 5\%. Seleksi berdasarkan bobot biji malai ${ }^{-1}$ dan tinggi tanaman meningkatkan hasil $21 \%$ dan mengurangi tinggi tanaman 6.9\%. Hal ini memberikan kesempatan untuk mendapatkan varietas unggul dengan tinggi tanaman yang lebih pendek.
\end{abstract}

Kata kunci : single seed descent, heritabilitas, diferensial seleksi 


\section{Pendahuluan}

Sorgum (Sorghum bicolor (L.) Moench) adalah tanaman pangan penting di dunia setelah beras, gandum, jagung, dan barley (Reddy et al. 2012). Sorgum termasuk tanaman multifungsi yang dapat digunakan sebagai sumber pangan, pakan, dan bioetanol (Dicko et al. 2006). Sorgum juga memiliki daya adaptasi yang luas karena kebutuhan input lebih sedikit dibandingkan dengan tanaman pangan lainnya serta toleran terhadap kondisi kekeringan (Biba 2011).

Komoditas sorgum belum mendapatkan prioritas untuk dikembangkan di Indonesia. Hal ini disebabkan karena nilai keunggulan komparatif dan kompetitif yang rendah (Sirappa 2003). Produktivitas sorgum di Indonesia pada tahun 2011 hanya mencapai 2.1 ton ha ${ }^{-1}$ (Ditjen Tanaman Pangan 2013). Dengan Penggunaan varietas unggul, petani dapat memanen sorgum hingga 5 ton ha ${ }^{-1}$ (Kelley et al. 1992). Oleh karena itu diperlukan penelitian dan pengembangan untuk menghasilkan varietas-varietas unggul sorgum dengan daya hasil yang lebih baik.

Peningkatan keragaman genetik populasi tanaman adalah langkah pertama dalam program pemuliaan tanaman (Phoelman \& Sleper 1996). Keragaman genetik yang luas merupakan dasar keberhasilan seleksi untuk menghasilkan varietas unggul. Keragaman genetik dapat dihasilkan melalui introduksi, mutasi, dan persilangan (Aquaah 2007). Upaya untuk meningkatkan variabilitas genetik sorgum melalui persilangan di Indonesia masih terbatas. Varietas unggul sorgum nasional yang ada saat ini dikembangkan melalui teknik mutasi dan introduksi, disamping itu jumlah varietas sorgum nasional masih terbatas sehingga usaha pengembangan varietas sorgum masih perlu dilakukan.

Departemen Agronomi dan Hortikultura, Fakultas Pertanian, Institut Pertanian Bogor telah melakukan program pemuliaan sorgum melalui persilangan pada tahun 2010. Persilangan B69 x Numbu dilakukan melalui metode single seed descent dan telah menghasilkan 201 F5 Recombinant Inbred Lines (RILs). RILs merupakan individu-individu tanaman hasil persilangan yang mengalami penyerbukan sendiri selama beberapa generasi dan tidak dilakukan kegiatan seleksi pada generasi sebelumnya. RILs F5 yang dikembangkan melalui single seed descent memiliki keragaman yang tinggi seperti generasi F2 dan seragam dalam galurnya (Kong et al. 2013; Phuong et al. 2013)

Komponen hasil dikendalikan oleh banyak gen yang ekspresinya sangat dipengaruhi oleh lingkungan (Miladivonic et al. 2011). Keragaman dari karakter hasil pada RILs F5 hasil SSD disebabkan oleh gen-gen aditif karena setiap galur berasal dari tanaman menyerbuk sendiri. Menurut Mangoendidjojo (2003) seleksi pada generasi lanjut melalui metode penggaluran single seed descent akan lebih efektif karena kontribusi gen-gen aditif terhadap keragaman genetik sudah semakin besar dan galur-galur yang dihasilkan sudah semakin homozigot.

Pendugaan parameter genetik bertujuan untuk memperoleh informasi dasar dalam perbaikan karakter tanaman melalui seleksi (Wardina \& Pranowo, 2011). Pendugaan parameter genetik untuk komoditi sorgum hasil metode single seed descent belum banyak dikaji lebih lanjut. Oleh karena itu diperlukan studi genetik untuk mendukung pemilihan varietas unggul sorgum. Tujuan penelitian ini adalah untuk memperoleh informasi tentang parameter genetik pada populasi RILs F5 hasil single seed descent dan melakukan seleksi galur-galur unggul sorgum berdaya hasil tinggi serta seragam dalam galurnya. 


\section{Metode Penelitian}

\section{Waktu dan Tempat}

Pecobaan dilakukan pada bulan Juli sampai Oktober 2014 di kebun milik petani Desa Setu Leutik, Dramaga, Bogor, Jawa Barat.

\section{Bahan Genetik}

Bahan genetik yang digunakan dalam penelitian ini adalah 201 RIL F5 sorgum (B69 x Numbu) hasil single seed descent dan 4 varietas kontrol (Numbu, Samurai-1, Samurai-2, dan galur mutan B69).

\section{Prosedur Percobaan}

Percobaan dilakukan dengan rancangan augmented design dengan faktor tunggal genotipe yang terdiri dari 201 RIL F5 dan 4 varietas kontrol. Varietas kontrol diulang 6 kali untuk menduga ragam galat. Unit percobaan yang digunakan adalah satu baris dengan jumlah 10 tanaman pada tiap baris.

Pengolahan tanah dilakukan satu minggu sebelum tanam. Jarak tanam antar baris adalah $75 \mathrm{~cm}$ sedangkan jarak dalam baris adalah $10 \mathrm{~cm}$. Pemberian pupuk urea dilakukan dua kali yaitu pada saat penanaman $50 \mathrm{~kg} \mathrm{ha}^{-1}$ bersamaan dengan pemberian pupuk SP-36 dan $\mathrm{KCl}$ masing-masing $100 \mathrm{~kg} \mathrm{ha}^{-1}$. Pemupukan urea kedua dilakukan pada saat tanaman telah berumur 4 MST dengan dosis 100 $\mathrm{kg} \mathrm{ha}^{-1}$. Panen dilakukan jika $80 \%$ tanaman dari satu galur sudah masak sempurna ditandai dengan munculnya lapisan hitam atau coklat pada biji dan apabila digigit biji sorgum pecah dan terasa tepungnya. Pengamatan dilakukan terhadap karakter umur panen (hari), umur berbunga (hari), periode pengisian biji (hari), laju pengisian biji $\left(\mathrm{g} \mathrm{hari}^{-1}\right)$, tinggi tanaman $(\mathrm{cm})$, diameter batang $(\mathrm{mm})$, jumlah daun (helai), panjang malai $(\mathrm{cm})$, lingkar malai $(\mathrm{cm})$, bobot malai $(\mathrm{g})$, dan bobot biji malai $^{-1}(\mathrm{~g})$.

\section{Pengamatan Karakter Agronomi}

1. Umur berbunga dihitung berdasarkan 50\% tanaman dalam satu satuan percobaan sudah mulai berbunga

2. Umur panen dihitung berdasarkan saat $50 \%$ tanaman dalam satu satuan percobaan sudah masak sempurna

3. Periode pengisian biji dihitung berdasarkan selisih umur panen dengan umur berbunga

4. Laju pengisian biji dihitung berasarkan perbandingan bobot biji malai ${ }^{-1}$ dengan periode pengisian biji

5. Tinggi tanaman diukur dari pangkal batang di permukaan tanah hingga ujung malai pada saat menjelang panen.

6. Diameter batang diukur pada ruas ketiga pada saat fase pengisian biji sorgum dengan menggunakan jangka sorong.

7. Jumlah daun dihitung mulai dari buku kedua pada saat menjelang panen

8. Panjang malai diukur dari leher malai sampai ke ujung malai pada saat panen.

9. Lingkar malai diukur pada bagian terbesar malai saat malai sudah kering

10. Bobot malai ditimbang setelah malai dikeringkan di bawah sinar matahari selama 3 hari.

11. Bobot biji malai ${ }^{-1}$ ditimbang setelah biji dikeringkan dan setelah biji dirontok. 


\section{Analisis Data}

Data dianalisis menggunakan perangkat lunak SAS versi 9.3 berdasarkan model analisis rancangan augmented Federer dan Nguyen (2002). Tabel 4.1 menunjukan sumber keragaman dari nilai kuadrat tengah harapan augmented.

Tabel 8. Analisis ragam rancangan augmented RKLT

\begin{tabular}{lcccc}
\hline $\begin{array}{c}\text { Sumber } \\
\text { keragaman }\end{array}$ & Derjat bebas & $\begin{array}{c}\text { Jumlah } \\
\text { kuadrat }\end{array}$ & $\begin{array}{c}\text { Kuadrat } \\
\text { tengah }\end{array}$ & $\begin{array}{c}\text { Kuadrat tengah } \\
\text { harapan }\end{array}$ \\
\hline Blok & $\mathrm{r}-1$ & $\mathrm{Jkb}$ & $\mathrm{Ktb}$ & \\
Genotipe & $(\mathrm{g}+\mathrm{c})-1$ & $\mathrm{JKp}$ & $\mathrm{KTp}$ & \\
$\quad$ Galur $(\mathrm{g})$ & $\mathrm{g}-1$ & $\mathrm{JKg}$ & $\mathrm{KTg}$ & $\sigma_{e}^{2}+\sigma_{g}^{2}$ \\
$\quad$ Kontrol $(\mathrm{c})$ & $\mathrm{c}-1$ & $\mathrm{JKc}$ & $\mathrm{KTc}$ & $\sigma_{e}^{2}+r \sigma_{c}^{2}$ \\
$\mathrm{~g} v s \mathrm{c}$ & 1 & $\mathrm{JK}(\mathrm{g} v s \mathrm{c})$ & $\mathrm{KT}(\mathrm{g} v s \mathrm{c})$ & \\
Error & $(\mathrm{c}-1)(\mathrm{r}-1)$ & $\mathrm{JKe}$ & $\mathrm{Kte}$ & $\sigma_{e}^{2}$ \\
Total & $(\mathrm{rc}+\mathrm{g})-1$ & $\mathrm{JKT}$ & & \\
\hline
\end{tabular}

Keterangan: $\mathrm{r}=$ ulangan dalam control, $\mathrm{c}=$ varietas control, $\mathrm{g}=$ galur RILs F5

Pendugaan nilai ragam berdasarkan $\mathrm{E}(\mathrm{KT})$ adalah sebagai berikut:

1. Ragam lingkungan $\left(\sigma_{\mathrm{e}}^{2}\right)=\mathrm{KT}_{\mathrm{e}} / \mathrm{r}$

2. Ragam Genetik $\left(\sigma_{\mathrm{g}}^{2}\right)=\left(\mathrm{KT}_{\mathrm{g}}-\mathrm{KT}_{\mathrm{e}}\right) / \mathrm{r}$

3. Ragam Fenotipik $\left(\sigma_{\mathrm{p}}^{2}\right)=\sigma_{\mathrm{g}}^{2}+\sigma_{\mathrm{e}}^{2}$

Luas atau sempitnya keragaman genetik suatu karakter ditentukan berdasarkan ragam galur dan standar deviasi ragam galur menurut rumus Pinaria et al. (1995) sebagai berikut:

$$
\sigma_{\sigma \mathrm{g}}^{2}=\sqrt{ } 2 / \mathrm{r}^{2}\left[\left(\mathrm{KT}_{\mathrm{g}}^{2} / \mathrm{db}_{\mathrm{g}}+2\right)+\left(\mathrm{KT}_{\mathrm{e}}^{2} / \mathrm{db}_{\mathrm{e}}+2\right)\right]
$$

Keterangan: $\mathrm{KT}_{\mathrm{e}}=$ kuadrat tengah galat; $\mathrm{KT}_{\mathrm{g}}=$ kuadrat tengah galur; $\mathrm{r}=$ ulangan; $\mathrm{db}_{\mathrm{g}}=$ derajat bebas galur; $\mathrm{db}_{\mathrm{e}}=$ derajat bebas galat. Apabila $\sigma_{\mathrm{g}}^{2}>\sigma_{\sigma \mathrm{g}}{ }^{2}$ : keragaman genetik luas, sedangkan $\sigma_{\mathrm{g}}^{2}<\sigma_{\sigma}{ }^{2}$ : keragaman genetik sempit.

Heritabilitas merupakan proporsi antara ragam genetik dengan ragam fenotipe yang dihitung berdasarkan rumus Falconer dan Mackay (1996), sebagai berikut:

$$
\mathrm{h}_{\mathrm{bs}}^{2}=\left(\frac{\sigma_{\mathrm{g}}^{2}}{\sigma_{\mathrm{p}}^{2}}\right) \times 100
$$

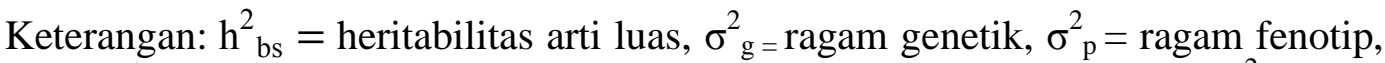
kemudian heritabilitas dikelompokan menjadi tiga yaitu tinggi jika $h^{2}>0.5$, sedang jika $0.2 \leq \mathrm{h}^{2} \leq 0.5$; dan rendah jika $\mathrm{h}^{2}<0.2($ Roy 2000).

Ragam dalam galur dan antar galur RIL F5 diduga dari ragam fenotipe pada RIL F5. Ragam fenotipe yang diamati dihitung berdasarkan Gomez dan Gomez (2007) yaitu;

$$
\sigma^{2}=\sum_{n-1}^{i}(x i-x)^{2} / n-1
$$


Keterangan: $\sigma^{2}=$ nilai ragam dalam galur atau antar galur, $x i=$ rataan tiap individu dalam galur atau tiap galur, $x=$ rataan umum dalam galur atau antar galur, $n=$ jumlah observasi.

Analisis korelasi digunakan untuk mengetahui korelasi antara karakter hasil dengan karakter agronomi lainnya. Analisis korelasi dilakukan dengan menggunakan program SAS.9.3. Secara statistik hubungan antar karakter agronomi diestimasi menggunakan rumus menurut Singh dan Chaudhary (1979):

$$
r_{x y}=\frac{n \sum x_{1} y_{1}-\left(\sum x_{1}\right)\left(\sum y_{1}\right)}{\sqrt{\left[n \sum x_{1}^{2}-\left(\sum x_{1}\right)^{2}\right]\left[n \sum y_{1}^{2}-\left(\sum y_{1}\right)^{2}\right]}}
$$

Keterangan: $r_{x y}=$ koefisien korelasi antara karakter agronomi terhadap karakter hasil, $\mathrm{n}=$ banyaknya perlakuan; $\mathrm{x}_{1}=$ karakter bebas; $\mathrm{y}_{1}=$ karakter hasil

Sidik lintas merupakan analisis yang membahas hubungan kausal antar variabel. Melalui analisis ini dapat diketahui pengaruh langsung dan tidak langsung antara variabel bebas dan respon. Analisis sidik lintas dilakukan dengan menggunakan program SAS.9.3. Secara statistik rumus sidik lintas menurut Gaspersz (1992) sebagai berikut:

$$
\begin{aligned}
& {\left[\begin{array}{lll}
r 11 & r 12 \ldots \ldots \ldots . r 1 \mathrm{p} \\
r 21 & r 22 \ldots \ldots \ldots r 2 \mathrm{p} \\
r \mathrm{p} 1 & r \mathrm{p} 2 \ldots \ldots \ldots . . \mathrm{pp}
\end{array}\right]\left[\begin{array}{l}
\mathrm{C} 1 \\
\mathrm{C} 2 \\
\mathrm{C} 3
\end{array}\right]=\left[\begin{array}{c}
r 1 y \\
r 2 y \\
r 3 y
\end{array}\right]} \\
& \mathrm{R} x \cdot \underline{\mathrm{C}}=\mathrm{R} y
\end{aligned}
$$

Keterangan:

$\mathrm{R} x=$ matriks korelasi antar variabel bebas dalam model regresi berganda yang memiliki $\mathrm{p}$ buah variabel bebas sehingga merupakan matriks dengan elemen-elemen $\mathrm{R}_{x i x j}(i, j=1,2, \ldots, \mathrm{p})$

$\underline{\mathrm{C}}=$ vektor koefisien lintasan yang menunjukkan pengaruh langsung dari setiap variabel bebas yang telah dibakukan

$\mathrm{Ry}=$ vektor koefisien korelasi antara variabel bebas $x i(i=1,2, \ldots, \mathrm{p})$ dan variabel tidak bebas $\mathrm{Y}$.

Seleksi galur berdaya hasil tinggi dilakukan berdasarkan satu karakter yaitu karakter bobot biji malai ${ }^{-1}$ dengan intensitas seleksi $15 \%$ serta berdasarkan 2 karakter sekaligus yaitu bobot biji malai ${ }^{-1}$ dan tinggi tanaman. Kemudian dilanjutkan dengan menghitung nilai diferensial seleksi dengan persamaan menurut Falconer dan Mackay (1996):

$$
\mathrm{S}=\frac{(\mathrm{Xi}-\mathrm{Xo})}{\mathrm{Xo}} \times 100 \%
$$

Keterangan: $\mathrm{S}=$ diferensial seleksi, $\mathrm{Xi}=$ nilai tengah populasi terseleksi, $\mathrm{Xo}=$ nilai tengah populasi sebelum seleksi. 


\section{Hasil dan Pembahasan}

\section{Keragaan RILs F5 Sorgum (B69 x Numbu) di Dramaga}

Galur sorgum yang diuji dalam penelitian ini adalah Rekombinant Inbred Lines (RILs) F5 yang dikembangkan dengan metode single seed descent hasil persilangan antara B69 dan Numbu. Setiap RIL F5 ditanam ke dalam satu baris. RILs F5 berasal dari individu yang mengalami penyerbukan sendiri selama beberapa generasi dan tidak dilakukan kegiatan seleksi pada generasi sebelumnya.

Analisis ragam dilakukan untuk mengetahui pengaruh RILs F5 terhadap karakter yang diamati. Berdasarkan analisis ragam diketahui bahwa galur-galur RILs F5 yang diuji berbeda nyata pada karakter periode pengisian biji, tinggi tanaman, jumlah daun, panjang malai, lingkar malai, bobot malai, dan bobot biji malai $^{-1}$ (Tabel 9). Hal ini menunjukan adanya perbedaan nilai tengah yang nyata di antara RILs F5 pada karakter periode pengisian biji, tinggi tanaman, jumlah daun, panjang malai, lingkar malai, bobot malai, dan bobot biji malai ${ }^{-1}$.

Arunkumar et al. (2004) dan Kamatar et al. (2015) melaporkan bahwa terdapat pengaruh galur terhadap keragaan karakter tinggi tanaman, jumlah daun, panjang malai, lingkar malai, bobot malai dan bobot biji malai ${ }^{-1}$ di lingkungan optimum. Sami et al. (2013a) melaporkan terdapat pengaruh galur terhadap keragaan karakter tinggi tanaman, jumlah daun, panjang malai, bobot malai, dan bobot biji malai ${ }^{-1}$ pada dua lokasi dengan ketinggian 686 dan $500 \mathrm{~m}$ dpl. Mallinath et al. (2004) melaporkan terdapat pengaruh 107 galur terhadap keragaan karakter tinggi tanaman, jumlah daun, panjang malai, dan bobot biji malai ${ }^{-1}$ pada lingkungan optimum. Hal ini mengindikasikan galur yang dihasilkan dari persilangan tetua yang berbeda menunjukan keragaman untuk karakter agronomi.

Tabel 9 Kuadrat tengah RILs F5 (B69 x Numbu) dan varietas kontrol terhadap karakter agronomi sorgum.

\begin{tabular}{|c|c|c|c|c|c|c|c|}
\hline \multirow{3}{*}{ Karakter } & \multicolumn{6}{|c|}{ Sumber keragaman } & \multirow{3}{*}{$\begin{array}{l}\mathrm{KK} \\
(\%)\end{array}$} \\
\hline & \multicolumn{2}{|c|}{ Genotipe } & \multicolumn{2}{|c|}{ Galur } & \multicolumn{2}{|c|}{ Kontrol } & \\
\hline & KT & F-Hit & KT & F-Hit & KT & F-Hit & \\
\hline Umur berbunga & 23.3 & 1.5 & 23.1 & 1.5 & 23.3 & 1.5 & 6.2 \\
\hline Umur panen & 20.5 & 1.2 & 20.5 & 1.2 & 23.4 & 1.4 & 4.0 \\
\hline Periode pengisian biji & 41.7 & $2.3^{*}$ & 40.8 & $2.3^{*}$ & 60.4 & $3.3 *$ & 10.8 \\
\hline Laju pengisian biji & 0.0 & 1.0 & 0.0 & 0.9 & 0.1 & 2.0 & 16.0 \\
\hline Diameter batang & 4.1 & 1.7 & 3.8 & 1.6 & 16.9 & $7.2 * *$ & 11.0 \\
\hline Tinggi tanaman & 532.7 & $2.6^{*}$ & 514.7 & $0.0 *$ & 1603.1 & $7.9 * *$ & 6.6 \\
\hline Jumlah daun & 1.4 & $2.4^{*}$ & 1.2 & $2.1 *$ & 12.4 & $21.2^{* *}$ & 7.4 \\
\hline Panjang malai & 9.0 & $3.3 *$ & 6.9 & $2.5^{*}$ & 92.9 & $33.7 * *$ & 8.8 \\
\hline Lingkar malai & 3.6 & $2.2 *$ & 3.1 & $1.9 *$ & 11.2 & $6.8 * *$ & 8.7 \\
\hline Bobot malai & 381.4 & $2.7 *$ & 378.7 & $2.7 *$ & 630.6 & $4.5^{*}$ & 19.1 \\
\hline Bobot biji malai $^{-1}$ & 267.1 & $5.4 * *$ & 257.3 & $5.2 * *$ & 370.3 & $7.5 * *$ & 12.2 \\
\hline
\end{tabular}

Keterangan: $*$ berbeda nyata pada taraf $\alpha=5 \%, * *=$ berbeda nyata pada taraf $\alpha=1 \%$

Nilai koefisien keragaman (KK) dari percobaan ini berkisar antara 4.019.1\% dengan keragaman tertinggi terdapat pada karakter bobot malai (Tabel 9). 
Besaran nilai KK dapat digunakan sebagai pendeteksi apakah data yang diperoleh perlu ditransformasi atau tidak. Nilai KK lebih besar dari batas kewajaran mencerminkan bahwa unit percobaan yang digunakan tidak homogen dan merupakan indikasi bahwa data sebaiknya ditransformasi. Mattjik dan Sumertajaya (2006) menyatakan bahwa nilai KK 20-25\% pada bidang pertanian masih dianggap wajar. Nilai KK seluruh karakter dalam penelitian ini masih dianggap wajar. Besarnya nilai KK yang berada dalam kisaran ideal menunjukkan bahwa unit-unit percobaan yang digunakan homogen.

Varietas kontrol berpengaruh nyata terhadap karakter periode pengisian biji, diameter batang, tinggi tanaman, jumlah daun, panjang malai, lingkar malai, bobot malai, dan bobot biji malai ${ }^{-1}$ (Tabel 9). Perbedaan nilai di antara tanaman kontrol dilihat melalui uji lanjut DMRT (Tabel 10).

Tabel 10. Keragaan varietas kontrol sorgum

\begin{tabular}{lcccc}
\hline Karakter & Numbu & B69 & Samurai-1 & Samurai-2 \\
\hline Umur berbunga (hari) & 67.0 & 64.0 & 68.0 & 67.0 \\
Umur Panen (hari) & 103.0 & 103.0 & 100.0 & 105.0 \\
Periode Pengisian Biji (hari) & $36.0 \mathrm{ab}$ & $39.0 \mathrm{a}$ & $32.0 \mathrm{~b}$ & $38.0 \mathrm{a}$ \\
Laju pengisian biji (g hari $\left.{ }^{-1}\right)$ & 1.2 & 1.0 & 1.0 & 0.9 \\
Diameter Batang (mm) & $13.5 \mathrm{bc}$ & $12.8 \mathrm{c}$ & $15.4 \mathrm{ab}$ & $16.5 \mathrm{a}$ \\
Tinggi Tanaman (cm) & $224.0 \mathrm{a}$ & $196.0 \mathrm{~b}$ & $225.1 \mathrm{a}$ & $196.1 \mathrm{~b}$ \\
Jumlah Daun (helai) & $10.0 \mathrm{bc}$ & $9.0 \mathrm{c}$ & $13.0 \mathrm{a}$ & $11.0 \mathrm{~b}$ \\
Panjang malai (cm) & $17.3 \mathrm{~b}$ & $18.6 \mathrm{~b}$ & $24.2 \mathrm{a}$ & $25.2 \mathrm{a}$ \\
Lingkar malai (cm) & $14.6 \mathrm{a}$ & $13.4 \mathrm{ab}$ & $11.7 \mathrm{~b}$ & $11.9 \mathrm{~b}$ \\
Bobot malai (gr) & $74.3 \mathrm{a}$ & $58.4 \mathrm{~b}$ & $53.4 \mathrm{~b}$ & $51.8 \mathrm{~b}$ \\
Bobot biji malai $^{-1}$ (gr) & $56.2 \mathrm{a}$ & $44.3 \mathrm{~b}$ & $37.1 \mathrm{~b}$ & $45.2 \mathrm{~b}$ \\
\hline
\end{tabular}

Keterangan: angka pada baris yang sama jika diikuti huruf yang tidak sama berarti berbeda nyata berdasarkan uji DMRT pada taraf $\alpha=5 \%$.

Keragaman yang dimiliki setiap karakter berbeda pada setiap genotipe kontrol. Karakter periode pengisian biji tercepat terdapat pada genotipe Samurai-1 dan yang terlama terdapat pada genotipe B69. Karakter diameter batang terbesar terdapat pada genotipe Samurai-2 dan terkecil terdapat pada genotipe B69. Karakter tinggi tanaman tertinggi terdapat pada genotipe Samurai-1 dan terendah terdapat pada genotipe B69. Karakter jumlah daun terbanyak terdapat pada genotipe Samurai-1 dan sedikit terdapat pada genotipe B69. Karakter panjang malai terbesar terdapat pada genotipe Samurai-2 dan terkecil terdapat pada genotipe Numbu. Karakter lingkar malai terbesar terdapat pada genotipe Numbu dan terkecil terdapat pada genotipe Samurai-1. Karakter bobot biji malai ${ }^{-1}$ terbesar terdapat pada genotipe Numbu dan terkecil terdapat pada genotipe Samurai-1. Keragaman malai sorgum varietas kontrol dapat dilihat pada Gambar 11.

Penggunaan varietas kontrol dalam analisis ini adalah untuk memperoleh galat acak. Galat acak akan menghasilkan galat baku untuk membandingkan bahan genetik yang digunakan, disamping itu kegunaan kontrol adalah memulihkan kembali informasi yang hilang karena tidak adanya ulangan pada galur yang digunakan dengan cara menghilangkan pengaruh lingkungan apabila menggunakan rancangan acak berblok (Jambormias 2004).

Keragaan populasi RILs F5 ditampilkan pada Tabel 11. RILs F5 memiliki nilai maksimum lebih tinggi dari tetua pada semua karakter agronomi. Umur 
berbunga RILs F5 berkisar 55 hari sampai 76 hari, sedangkan rata-rata tetua Numbu sebesar $65 \pm 5.7$ hari dan B69 sebesar $64 \pm 3.0$ hari. Terdapat 99 galur F5 yang memiliki umur berbunga lebih rendah dibanding kedua tetua. Menurut Elangovan (2014) klasifikasi umur berbunga terdiri dari lima yakni sangat genjah (<56 hari), genjah (56-65 hari), sedang (66-75 hari), dalam (76-85 hari), dan sangat dalam ( $>85$ hari). Pada populasi RILs F5 terdapat 4 galur yang memiliki umur sangat genjah, 108 galur umur genjah, 86 galur umur sedang dan 3 galur umur dalam.

Tabel 11. Keragaan populasi RILs F5 sorgum hasil persilangan B69 x Numbu

\begin{tabular}{|c|c|c|c|c|}
\hline \multirow{2}{*}{ Karakter } & \multicolumn{2}{|c|}{ Rata-rata tetua } & \multirow{2}{*}{$\begin{array}{c}\text { Rata- } \\
\text { RILs } \\
\text { F5 }\end{array}$} & \multirow{2}{*}{$\begin{array}{l}\text { Kisaran } \\
\text { RILs F5 }\end{array}$} \\
\hline & Numbu & B69 & & \\
\hline Umur berbunga (hari) & $65.0 \pm 5.7$ & $64.0 \pm 3.0$ & 64.3 & $55.0-76.0$ \\
\hline Umur panen (hari) & $103.0 \pm 1.2$ & $103.0 \pm 1.2$ & 104.0 & $88.0-117.0$ \\
\hline Periode pengisian biji (hari) & $36.3 \pm 4.6$ & $39.3 \pm 2.7$ & 39.5 & $27.0-60.0$ \\
\hline Laju pengisian biji $\left(\mathrm{g}\right.$ hari $\left.^{-1}\right)$ & $1.5 \pm 0.7$ & $1.1 \pm 0.1$ & 1.4 & $0.4-\quad 3.1$ \\
\hline Diameter batang (mm) & $13.5 \pm 2.1$ & $12.8 \pm 1.1$ & 13.8 & $8.5-18.4$ \\
\hline Tinggi tanaman $(\mathrm{cm})$ & $224.1 \pm 15.5$ & $196.4 \pm 5.5$ & 217.0 & $157.4-275.8$ \\
\hline Jumlah daun (helai) & $10.1 \pm 0.6$ & $9.2 \pm 0.7$ & 10.3 & $7.0-13.0$ \\
\hline Panjang malai $(\mathrm{cm})$ & $17.3 \pm 1.4$ & $18.6 \pm 1.6$ & 18.5 & $11.8-26.2$ \\
\hline Lingkar malai $(\mathrm{cm})$ & $14.6 \pm 2.1$ & $13.4 \pm 0.8$ & 15.0 & $9.6-20.1$ \\
\hline Bobot malai (g) & $74.3 \pm 22.2$ & $58.4 \pm 5.3$ & 62.4 & $10.6-113.8$ \\
\hline Bobot biji malai $^{-1}(\mathrm{~g})$ & $56.2 \pm 6.9$ & $44.3 \pm 2.5$ & 55.2 & $21.2-101.2$ \\
\hline
\end{tabular}

Umur panen RILs F5 berkisar 88 HST sampai 117 HST, sedangkan ratarata tetua Numbu dan B69 sebesar $103.0 \pm 1.2$ HST. Menurut Hoeman et al. (2012) sorgum dengan daya hasil tinggi biasanya diperoleh dari varietas yang memiliki umur panen 100 sampai 120 HST. Hal ini mengindikasikan kisaran umur berbunga pada RIL F5 sorgum memiliki potensi untuk menghasilkan galurgalur berdaya hasil tinggi. Terdapat 72 galur F5 yang memiliki umur panen lebih rendah dibanding kedua tetua.

Periode pengisian biji merupakan rentang waktu yang digunakan tanaman untuk memaksimalkan pengisian cadangan makanan pada biji. Umur berbunga dan umur panen adalah dua karakter yang mempengaruhi lama periode pengisian biji. Periode pengisian biji RILs F5 berkisar 27 hari sampai 60 hari, sedangkan rata-rata tetua Numbu sebesar $36.0 \pm 4.6$ hari dan B69 sebesar $39.0 \pm 2.7$ hari. Terdapat 55 galur F5 yang memiliki periode pengisian biji lebih rendah dibanding kedua tetua.

Laju pengisian biji merupakan karakter yang menunjukan kemampuan tanaman mentranslokasikan asimilat ke biji selama masa pengisian biji (Naserian et al. 2007). Laju pengisian biji RILs F5 berkisar $0.4 \mathrm{~g}_{\text {hari }}{ }^{-1}$ sampai $3.1 \mathrm{~g}$ hari $^{-1}$, sedangkan rata-rata tetua Numbu sebesar $1.5 \pm 0.7 \mathrm{~g} \mathrm{hari}^{-1}$ dan B69 sebesar $1.1 \pm$ 0.1 g hari $^{-1}$. Terdapat 67 galur F5 yang memiliki laju pengisian biji lebih tinggi dibanding kedua tetua.

Diameter batang galur F5 berkisar $8.5 \mathrm{~mm}$ sampai $18.4 \mathrm{~mm}$, sedangkan rata-rata tetua Numbu sebesar $13.5 \pm 2.1$ dan B69 sebesar $12.8 \pm 1.1$. Terdapat 118 RIL F5 yang memiliki diameter batang lebih besar dibanding kedua tetua. 
Menurut Elangovan (2014) klasifikasi diameter batang terdiri dari tiga yakni kecil $(<2 \mathrm{~cm})$, sedang $(2-4 \mathrm{~cm})$, dan besar $(>4 \mathrm{~cm})$. Pada populasi RILs F5 terdapat 143 galur yang tergolong kecil dan 58 galur yang tergolong sedang.

Tinggi tanaman galur F5 berkisar $157.4 \mathrm{~cm}$ sampai $275.8 \mathrm{~cm}$, sedangkan rata-rata tetua Numbu sebesar $224.1 \pm 15.5 \mathrm{~cm}$ dan B69 sebesar $196.4 \pm 5.5 \mathrm{~cm}$. Terdapat 36 RIL F5 yang memiliki tinggi tanaman lebih rendah dibanding kedua tetua. Tinggi tanaman yang rendah diharapkan akan mengurangi resiko rebah batang dan mempermudah pemanenan Menurut Elangovan (2014) klasifikasi tinggi tanaman terdiri dari tiga yakni pendek $(76-150 \mathrm{~cm})$, sedang $(151-225 \mathrm{~cm})$, dan tinggi (226-300). Terdapat 124 galur yang tergolong sedang, 77 galur yang tergolong tinggi, dan tidak terdapat galur yang tergolong pendek pada populasi RILs F5.

Jumlah daun RILs F5 berkisar 7 sampai 13 helai, sedangkan rata-rata tetua Numbu sebesar 10.1 \pm 0.6 helai dan B69 sebesar 9.2 \pm 0.7 helai. Menurut House (1985) jumlah daun sorgum yang beradaptasi baik dengan lingkungannya berkisar antara 6-13 helai.Terdapat 86 galur F5 yang memiliki jumlah daun lebih banyak dibanding kedua tetua .

Panjang malai RILs F5 berkisar $11.8 \mathrm{~cm}$ sampai $26.2 \mathrm{~cm}$, sedangkan ratarata tetua Numbu sebesar $17.3 \pm 1.4 \mathrm{~cm}$ dan B69 sebesar $18.6 \pm 1.6 \mathrm{~cm}$. Menurut House (1985) panjang malai sorgum berkisar antara 4-25 cm. Terdapat 90 galur F5 yang memiliki panjang malai lebih tinggi dibanding kedua tetua. Menurut Elangovan (2014) klasifikasi panjang malai terdiri dari lima yakni sangat pendek $(<11 \mathrm{~cm})$, pendek $(11-20 \mathrm{~cm})$, sedang $(21-30 \mathrm{~cm})$, panjang $(31-40 \mathrm{~cm})$, dan sangat panjang $(>40 \mathrm{~cm})$. Pada populasi RILs F5 terdapat 145 galur yang tergolong pendek dan 56 galur yang tergolong sedang. Lingkar malai RILs F5 berkisar 9.6 cm sampai $20.1 \mathrm{~cm}$, sedangkan rata-rata tetua Numbu sebesar $14.6 \pm 2.1 \mathrm{~cm}$ dan B69 sebesar $13.4 \pm 0.8 \mathrm{~cm}$. Terdapat 110 galur F5 yang memiliki lingkar malai lebih besar dibanding kedua tetua. Keragaman malai sorgum populasi RILs F5 dapat dilihat pada Gambar 11.

Nilai tengah bobot malai populasi RILs F5 berkisar 10.6 sampai $113.8 \mathrm{~g}$, sedangkan rata-rata tetua Numbu sebesar $74.3 \pm 22.2 \mathrm{~g}$ dan B69 sebesar $58.4 \pm$ 5.3 g. Terdapat 57 galur F5 yang memiliki bobot malai lebih tinggi dibanding kedua tetua. Bobot biji malai ${ }^{-1}$ RILs F5 berkisar $21.2 \mathrm{~g}$ sampai $101.2 \mathrm{~g}$ sedangkan

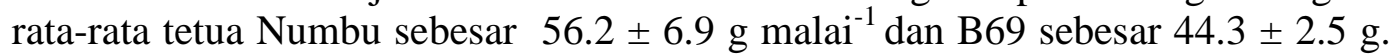
Terdapat 94 galur F5 yang memiliki bobot biji malai ${ }^{-1}$ lebih tinggi dibanding kedua tetua. Bobot biji merupakan karakter komponen hasil yang penting karena memiliki pengaruh langsung terhadap indeks panen dan hasil (Zecevic et al. 2010). Sorgum berdaya hasil tinggi berkorelasi positif dengan ukuran malai dan bobot malai (Poehlman \& Sleper 2006). Oleh karena itu pada penelitian ini diharapkan galur-galur yang memiliki panjang malai, lingkar malai, dan bobot malai yang tinggi akan menghasilkan bobot biji malai ${ }^{-1}$ yang tinggi.

\section{Parameter Genetik Karakter Agronomi RILs F5 Sorgum (B69 x Numbu)}

Keragaman yang diharapkan pada populasi RILs F5 yang diuji adalah keragaman yang disebakan oleh ragam genetik. Ragam genetik merupakan ragam yang diwariskan dari tetua terhadap turunannya. Ragam genetik dapat menunjukan besar atau kecilnya nilai heritabilitas yang dimiliki suatu karakter 
Semakin tinggi nilai heritabilitas berarti keragaan suatu karakter yang diamati sebagian besar dipengaruhi oleh ragam genetik (Falconer \& Mackay 1996). Luas atau sempitnya keragaman genetik suatu karakter ditentukan berdasarkan ragam genetik dan standar deviasi ragam genetik. Menurut Haq et al. (2008) keragaman genetik yang tergolong luas mengindikasikan bahwa karakter tersebut memiliki keragaman genetik yang tinggi sehingga karakter tersebut sangat potensial sebagai karakter seleksi.

Tabel 12. Pendugaan parameter genetik karakter agronomi RILs F5 sorgum

\begin{tabular}{|c|c|c|c|c|c|}
\hline Karakter & $\sigma_{\mathrm{e}}^{2}$ & $\sigma_{g}^{2}$ & $\sigma_{p}^{2}$ & $\mathrm{H}_{\mathrm{bs}}(\%)$ & $2\left(\sigma_{\sigma}^{2}\right)$ \\
\hline Umur berbunga & 2.6 & 1.2 & 3.8 & $31.0^{\mathrm{S}}$ & $1.9^{\mathrm{s}}$ \\
\hline Umur panen & 2.8 & 0.6 & 3.4 & $16.0^{\mathrm{R}}$ & $2.1^{\mathrm{S}}$ \\
\hline Periode pengisian biji & 3.0 & 3.8 & 6.8 & $56.0^{\mathrm{T}}$ & $2.5^{\mathrm{L}}$ \\
\hline Laju pengisian biji & 0.0 & 0.0 & 0.0 & $0.0^{\mathrm{R}}$ & $0.0^{\mathrm{S}}$ \\
\hline Diameter batang & 0.4 & 0.3 & 0.6 & $39.0^{\mathrm{S}}$ & $0.3^{\mathrm{S}}$ \\
\hline Tinggi tanaman & 33.7 & 55.1 & 85.8 & $60.0^{\mathrm{T}}$ & $28.7^{\mathrm{L}}$ \\
\hline Jumlah daun & 0.1 & 0.1 & 0.2 & $52.0^{\mathrm{T}}$ & $0.1^{\mathrm{L}}$ \\
\hline Panjang malai & 0.5 & 0.7 & 1.1 & $60.0^{\mathrm{T}}$ & $0.4^{\mathrm{L}}$ \\
\hline Lingkar malai & 0.3 & 0.3 & 0.6 & $50.0^{\mathrm{T}}$ & $0.2^{\mathrm{L}}$ \\
\hline Bobot malai & 23.5 & 39.7 & 63.1 & $63.0^{\mathrm{T}}$ & $20.4^{\mathrm{L}}$ \\
\hline Bobot biji malai $^{-1}$ & 8.2 & 34.7 & 42.9 & $81.0^{\mathrm{T}}$ & $10.2^{\mathrm{L}}$ \\
\hline
\end{tabular}

Generasi lanjut RILs F5 hasil single seed descent dapat mempertahankan keragaman genetik. Hal ini dibuktikan sebagian besar karakter agronomi memiliki heritabilitas yang tinggi dan keragaman genetik yang luas (Tabel 12). Metode single seed descent setiap galur dari generasi awal diturunkan sampai generasi lanjut sehingga frekuensi gen tetap terjaga seperti generasi F2 namun frekuensi genotipe mengalami peningkatan dimana frekuensi genotipe homozigot bertambah namun frekuensi genotipe heterozigot berkurang. Hal ini menyebabkan keragaman genetik dari populasi F2 tetap tinggi pada populasi RILs F5. Sesuai dengan pernyataan Roy (2000) galur generasi lanjut hasil single seed descent dapat mempertahankan keragaman genetik seperti generasi awal dan memiliki keragaman yang tinggi antar galur serta seragam dalam galurnya. Keragaman malai sorgum pada populasi RILs F5 dapat dilihat pada Gambar 12.

Karakter yang memiliki keragaman genetik luas dan heritabiitas tinggi pada generasi lanjut RILs F5 hasil SSD dari persilangan di antara tetua mengindikasikan bahwa karakter tersebut dipengaruhi oleh gen-gen aditif. Menurut Mangoendidjojo (2003) pada populasi hasil single seed descent seleksi dilakukan pada generasi lanjut yang mengakibatkan gen-gen aditif akan terfiksasi lebih besar. Hal ini menyebabkan nilai $\mathrm{h}_{\text {bs }}^{2}$ sebagai perkiraan yang baik dari $\mathrm{h}^{2}{ }_{\mathrm{ns}}$. Menurut Falconer dan Mackay (1996) heritabilitas yang tinggi bermanfaat dalam seleksi jika ragam genetik didominasi oleh ragam aditif, karena pengaruh aditif setiap alel akan diwariskan dari tetua pada turunannya. Berdasarkan nilai heriabilitas karakter periode pengisian biji, tinggi tanaman, jumlah daun, panjang malai, lingkar malai, bobot malai, dan bobot biji malai ${ }^{-1}$ dapat berpotensi digunakan sebagai karakter seleksi. 

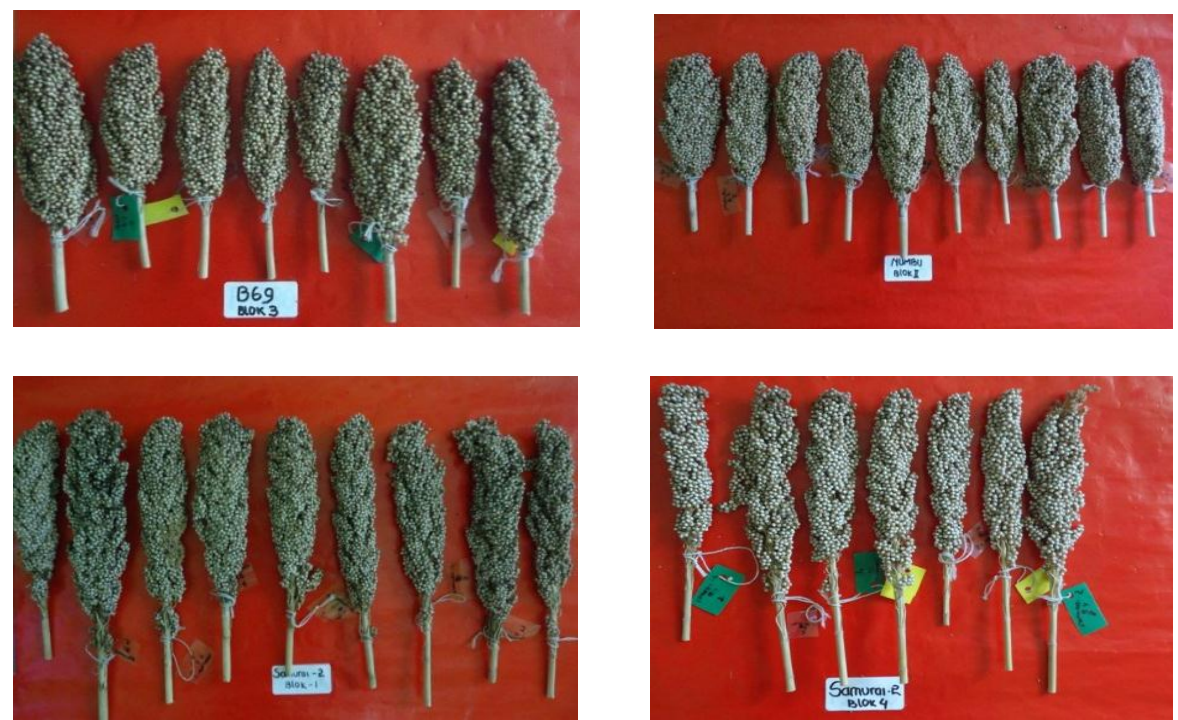

Gambar 11 Keragaman malai sorgum pada varietas kontrol
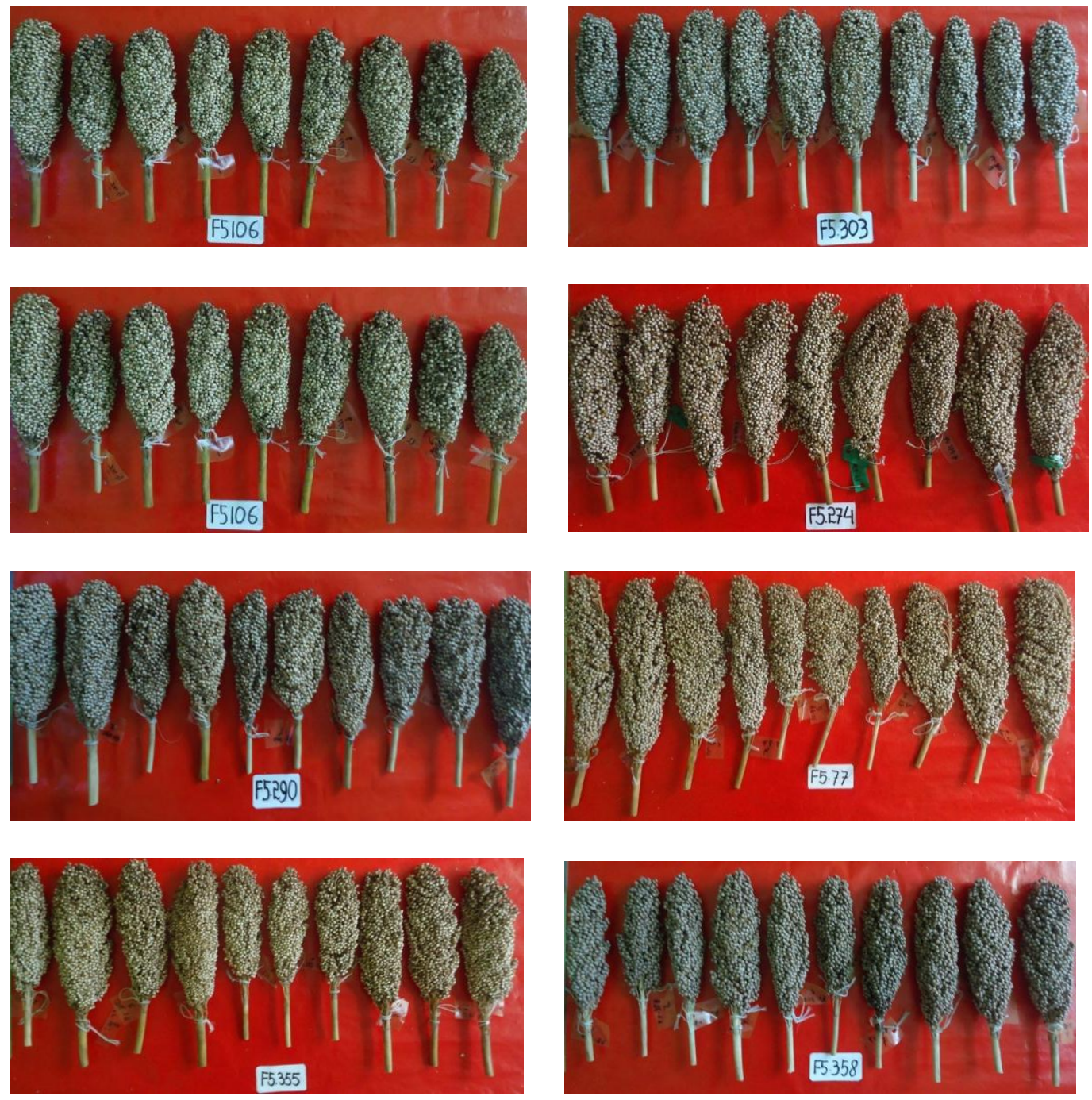

Gambar 12 Keragaman malai sorgum pada RILs F5 (B69 x Numbu) 


\section{Korelasi Antar Karakter Agronomi RILs F5 Sorgum}

Analisis korelasi menunjukan keeratan hubungan antara karakter yang diamati. Keeratan hubungan pada dua karakter dapat dilihat melalui nilai koefisien korelasi. Menurut Singh dan Chaudary (1979) nilai koefesien korelasi berada di antara -1 dan +1 dengan nilai korelasi mendekati 1 menunjukkan hubungan linear yang sempurna dan nilai korelasi nol menunjukkan tidak ada hubungan antara kedua karakter.

Bobot biji malai ${ }^{-1}$ merupakan karakter hasil. Karakter tersebut menjadi karakter utama untuk tujuan perbaikan dalam program pemuliaan tanaman. Karakter yang berkorelasi nyata dengan bobot biji malai ${ }^{-1}$ dapat dijadikan karakter seleksi untuk mendapatkan galur-galur yang memiliki potensi hasil tinggi. Oleh karena itu hubungan antara karakter agronomi dengan karakter bobot biji malai ${ }^{-1}$ sangat penting untuk diketahui.

Karakter tinggi tanaman dan diameter batang berkorelasi positif nyata terhadap bobot biji malai ${ }^{-1}$ (Tabel 13), artinya pertambahan tinggi tanaman dan diameter batang tanaman sorgum akan diikuti dengan pertambahan bobot biji malai $^{-1}$. Hal ini sesuai dengan penelitian Puspiasari et al. (2012); Sumiyati (2011) yang menyatakan bahwa karakter diameter batang dan tinggi tanaman dapat digunakan sebagai karakter seleksi untuk pemuliaan sorgum pangan berdaya hasil tinggi, namun tanaman yang terlalu tinggi cenderung rebah dan tidak efektif dijadikan sebagai karakter seleksi sehingga tidak boleh menyeleksi tanaman hanya berdasarkan karakter tinggi tanaman saja.

Berdasarkan uji korelasi umur panen tidak berkorelasi dengan bobot biji malai, sementara umur berbunga berkorelasi negatif dan nyata dengan bobot biji malai $^{-1}$ (Tabel 13), artinya semakin genjah umur berbunga maka semakin tinggi bobot biji malai ${ }^{-1}$. Hal ini dibuktikan dengan sebagian besar RIL F5 yang memiliki umur berbunga yang tergolong genjah dan sedang. Percobaan yang dilakukan oleh Reddy et al. (2012) menunjukkan bahwa umur panen tidak berkorelasi dengan hasil biji, namun umur berbunga berkorelasi negatif dan nyata dengan hasil biji.

Cepat lambatnya umur berbunga dipengaruhi oleh inensitas cahaya matahari, suhu harian, dan genotipe tanaman itu sendiri. Intensitas cahaya matahari yang tinggi dan suhu tinggi akan mempercepat proses pembungaan (Poehlman \& Sleper 1996). Hal ini sesuai dengan percobaan yang dilakukan di Dramaga ketika memasuki masa pembungaan curah hujan cukup rendah berkisar $50 \mathrm{~mm}$ dan suhu harian lingkungan mencapai $29^{\circ} \mathrm{C}$ (Lampiran 2). Menurut Ismail dan Kodir (1977) curah hujan yang rendah pada stadia pembungaan akan memperlancar proses pembentukan biji sehingga dapat meningkatkan hasil biji.

Laju pengisian biji berkorelasi positif dan nyata terhadap bobot biji malai ${ }^{-1}$. Hal ini disebabkan laju pengisian biji merupakan karakter yang menunjukan kemampuan tanaman dalam mentranslokasikan asimilat ke biji selama masa periode pengisian biji. Semakin besar laju pengisian biji mengakibatkan semakin besar asimilat yang ditranslokasikan ke biji sorgum yang mengakibatkan peningkatan terhadap bobot biji (Naserian et al. 2007). Menurut Munier Jolain dan Ney (1998) laju pengisian biji yang tinggi dan berlangsung relatif lama akan menghasilkan bobot biji yang tinggi selama biji sebagai sink dapat menampung hasil asimilat. Cepat atau lambatnya laju pengisian biji bergantung pada bobot biji malai $^{-1}$ dan periode pengisian biji. Menurut Mustafavi dan Ross (1990) bobot biji 
adalah hasil perkalian antara laju pengisian biji dengan periode pengisian biji, artinya semakin tinggi laju pengisian biji maka akan menyebabkan peningkatan terhadap bobot biji serta akan mempersingkat masa umur panen menjadi lebih pendek. Hal ini sesuai dengan penelitian Bustamam (2004) dan hasil analisis korelasi pada penelitian ini dimana terdapat korelasi yang positif dan nyata antara laju pengisian biji dengan bobot biji malai ${ }^{-1}$ namun memiliki korelasi negatif yang nyata dengan umur panen sehingga laju pengisan biji dapat dijadikan salah satu karakter yang perlu dipertimbangkan untuk menghasilkan galur sorgum berdaya hasil dengan umur panen yang singkat.

Analisis korelasi karakter hasil terhadap bobot biji malai ${ }^{-1}$ ditunjukan pada Tabel 13. Seluruh karakter hasil seperti panjang malai, lingkar malai, dan bobot malai berkorelasi positif dan nyata terhadap bobot biji malai ${ }^{-1}$. Bobot malai juga berkorelasi positif dan nyata dengan panjang malai dan lingkar malai. Panjang malai berkorelasi positif dan nyata terhadap lingkar malai. Hal ini mengindikasikan peningkatan bobot biji malai ${ }^{-1}$ akan diikuti oleh peningkatan karakter bobot malai, panjang malai, dan lingkar malai.

Panjang malai berkorelasi positif dan nyata dengan bobot malai. Hal ini menujukkan bahwa semakin panjang malai sorgum, maka bobot malai akan semakin tinggi. Secara botani panjang malai merupakan ruang tempat biji sorgum berada. Malai memiliki sumbu malai sebagai tempat cabang malai menempel. Cabang malai tempat biji menempel terdapat dalam susunan kompak, longgar atau intermediet (House 1985). Berdasarkan hal tesebut tersebut semakin panjang malai sorgum, maka semakin banyak cabang malai dan jumlah bijinya, sehingga bobot malai akan semakin tinggi.

Korelasi positif dan nyata ditunjukkan oleh panjang malai dengan bobot biji malai ${ }^{-1}$. Hal ini sesuai dengan penelitian Puspitasari (2011). Hubungan ini menunjukkan semakin panjang malai sorgum, maka bobot biji malai ${ }^{-1}$ akan semakin meningkat. Bobot malai memiliki korelasi positif, nyata dan memiliki nilai korelasi yang tinggi dibandingkan karakter lainnya terhadap bobot biji malai $^{-1}$. Hal ini sesuai dengan penelitian Din et al. (2012). Tingginya keeratan hubungan antara dua karakter ini menunjukkan bahwa secara linear peningkatan bobot malai akan selalu diikuti dengan peningkatan bobot biji malai ${ }^{-1}$. Fenomena ini tidak terlepas dari hubungan kausal yang terjadi sebelumnya dimana semakin panjang malai maka bobot malai akan meningkat yang akhirnya diikuti oleh meningkatnya bobot biji malai ${ }^{-1}$.

Karakter yang berkorelasi dengan bobot biji malai ${ }^{-1}$ dapat digunakan sebagai karakter seleksi. Nilai korelasi merupakan gambaran tingkat keeratan antar karakter yang satu dengan karakter yang lain. Nilai korelasi tidak dapat menjelaskan seberapa besar pengaruh langsung dan tidak langsung yang dimiliki suatu karakter terhadap karakter bobot biji malai ${ }^{-1}$, untuk mengetahui besarnya kontribusi karakter agronomi yang diamati terhadap bobot biji malai ${ }^{-1}$ dapat dilakukan melalui analisis lintasan.

\section{Analisis Lintasan}

Pemilihan karakter seleksi pada program pemuliaan tanaman juga membutuhkan informasi tentang kontribusi relatif dari masing-masing karakter agronomi terhadap hasil, baik langsung maupun tidak langsung. Dengan 
menggunakan analisis lintasan kebutuhan tersebut dapat terpenuhi. Analisis lintasan dapat menutupi kekurangan yang terdapat pada analisis korelasi, yaitu adanya saling interaksi antara karakter agronomi yang membuat penafsiran menjadi tidak akurat (Singh \& Chaudhary 1979). Analisis lintasan juga selalu diikuti dengan diagram lintasan yang bertujuan memperjelas uraian yang dikemukakan .

Berdasarkan Tabel 14 dan Gambar 13 sembilan karakter yang memperoleh nilai korelasi yang nyata, setidaknya terdapat lima karakter yang memiliki pengaruh langsung yang berpengaruh terhadap karakter bobot biji malai ${ }^{-1}$. karakter-karakter tersebut yaitu bobot malai (0.41) laju pengisian biji (0.41), tinggi tanaman (0.23), lingkar malai (0.19), dan periode pengisian biji (0.12). Menurut Safuan et al. (2014) karakter yang memiliki pengaruh langsung kurang dari 0.05 maka secara statistik dapat diabaikan pengaruhnya.

Hasil analisis lintasan menunjukkan bahwa dua variabel bebas yang memiliki pengaruh langsung terbesar terhadap bobot biji malai ${ }^{-1}$ adalah bobot malai dan laju pengisian biji. Pengaruh langsung bobot malai dan laju pengisian biji terhadap bobot biji malai ${ }^{-1}$ sebesar 0.41 . Nilai pengaruh langsung jumlah bobot malai dan laju pengisian biji terhadap hasil lebih tinggi dari karakter lainnnya, diduga karena kedua karakter tersebut secara botanis lebih dekat hubungannya dengan hasil dibandingkan karakter lainnya.

Karakter jumlah daun dan diameter batang memiliki pengaruh langsung yang negatif yaitu sebesar -0.12 dan -0.01 , namun pengaruh totalnya bernilai positif. Hal ini dikarenakan adanya pengaruh tidak langsung melalui karakter laju pengisian biji dan bobot malai yang memiliki kontribusi lebih besar terhadap dua karakter tersebut (Tabel 14). Menurut Singh dan Chaudhary (1979) pengaruh tidak langsung menjadi penyebab adanya nilai korelasi, apabila pengaruh total positif namun pengaruh langsungnya bernilai negatif. Dari hasil tersebut dapat diambil kesimpulan bahwa kenaikan jumlah daun dan diameter batang akan meningkatkan laju pengisian biji dan bobot malai yang selanjutnya akan meningkatkan bobot biji malai ${ }^{-1}$.

Berdasarkan Gambar 13 secara geometrik data ditampilkan dalam bentuk diagram lintasan untuk menjelaskan hubungan kausal antara variabel bebas dan variabel respon. Gambar 13 menunjukkan bahwa analisis lintasan mampu menjelaskan keragaman total dari variabel respon bobot biji malai ${ }^{-1}$ yang diterangkan dengan menggunakan 9 variabel sebesar 85\%, sedangkan sisanya sebesar $15 \%$ dipengaruhi oleh faktor lain.

Berdasarkan hasil analisis korelasi dan analisis lintas yang dilakukan pada percobaan ini telah diketahui hubungan sepuluh karakter agronomi dengan karakter bobot biji malai ${ }^{-1}$. Hubungan karakter tersebut menjadi dasar dalam menyusun karakter seleksi. Karakter - karakter yang dapat digunakan sebagai karakter seleksi memiliki beberapa syarat yaitu (1) berkorelasi kuat terhadap karakter target; (2) memiliki heritabilitas yang tinggi; (3) mudah diamati secara visual (Roy 2000). Hal ini ditambahkan Natawijaya (2012) dimana karakter yang berkorelasi kuat namun berpengaruh langsung rendah terhadap karakter bobot biji malai $^{-1}$ dapat dipertimbangkan sebagai karakter untuk menyusun kriteria seleksi dengan syarat nilai heritabilitasnya tinggi. Berdasarkan hal tersebut karakter tinggi tanaman, panjang malai, lingkar malai, bobot malai, dan bobot biji malai ${ }^{-1}$ dapat direkomendasikan sebagai karakter seleksi untuk perbaikan potensi hasil. 


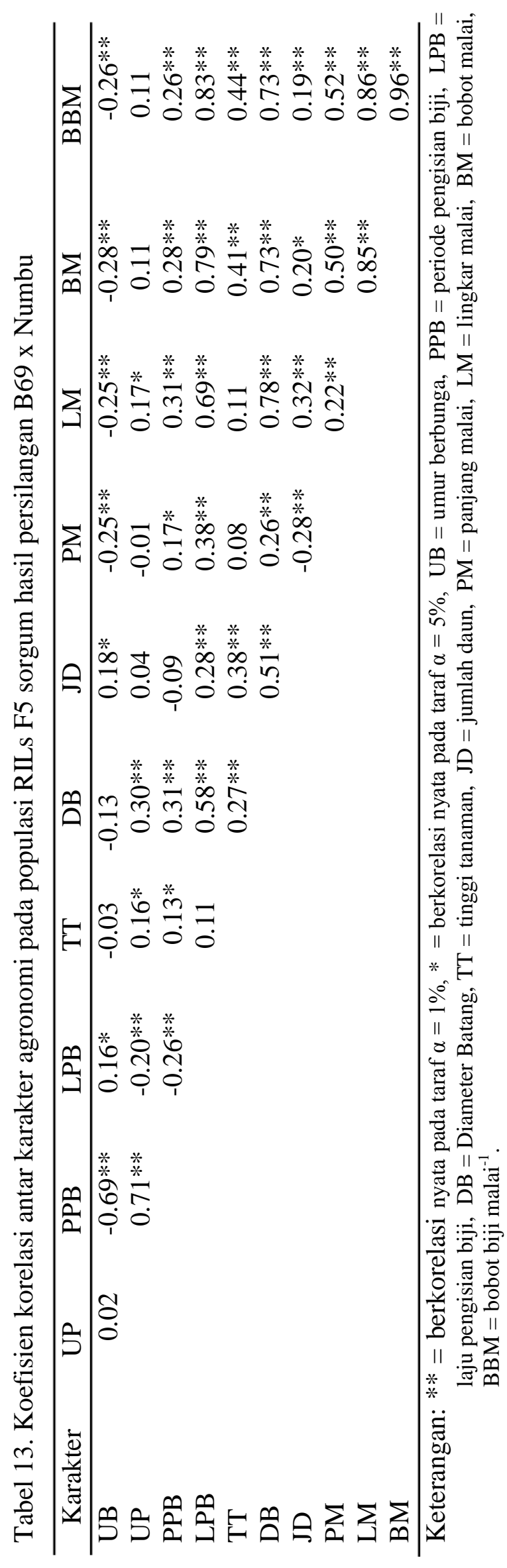




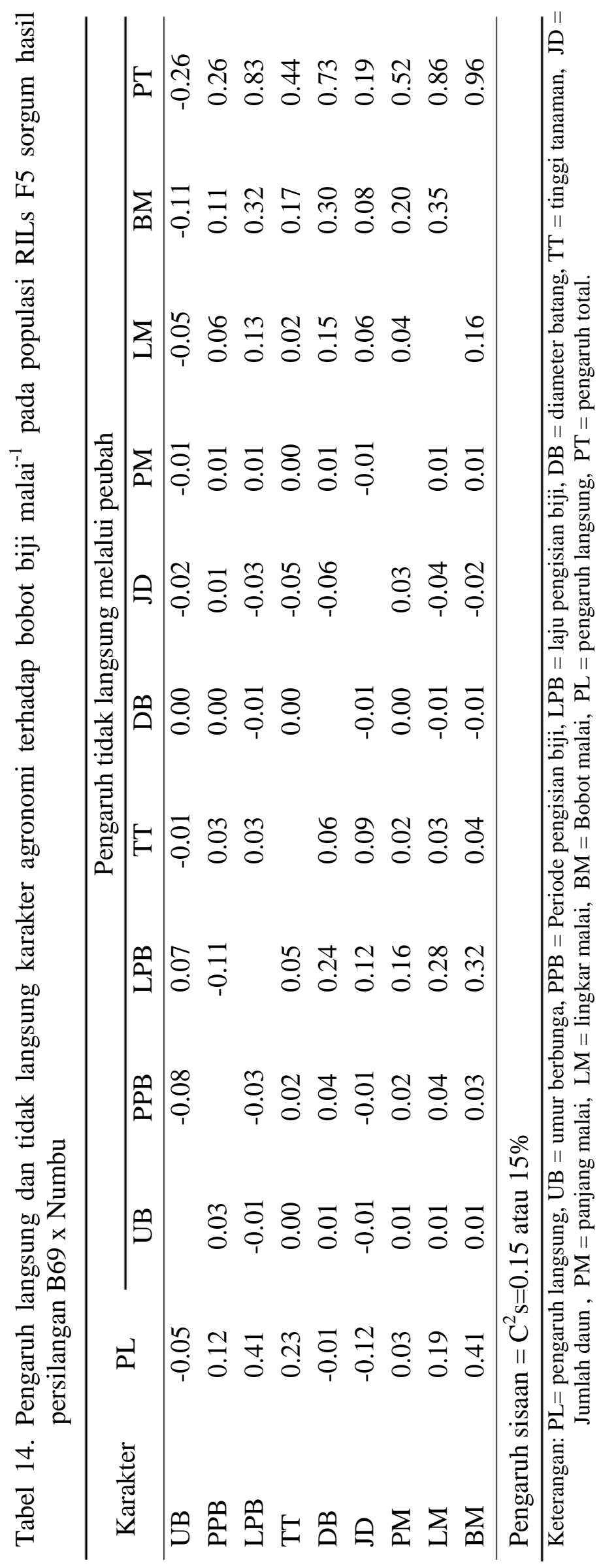




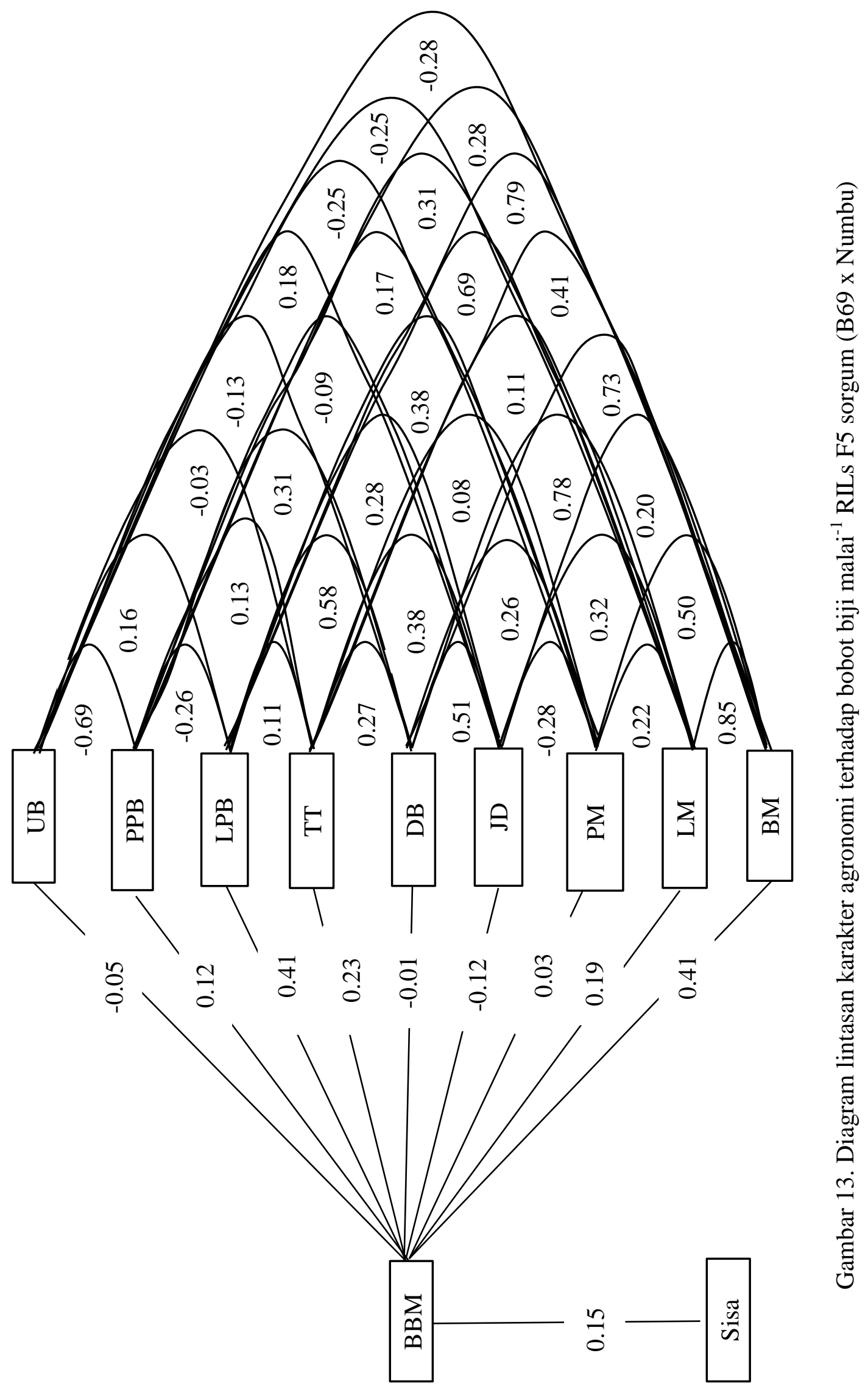




\section{Seleksi Galur-Galur RILs F5 Sorgum (B69 x Numbu)}

Seleksi merupakan prosedur memilih sejumlah individu dari suatu populasi dan membiarkannya membentuk generasi baru. Seleksi tidak menimbulkan keragaman baru tetapi dapat menghasilkan populasi hasil seleksi dengan nilai tengah yang lebih baik dari populasi asalnya (Chahal \& Gosal 2003). Kemajuan seleksi pada karakter kuantitatif ditunjukan oleh perubahan atau perbaikan nilai tengah dari generasi yang diturunkan dari populasi terseleksi (Roy 2000). Kemajuan seleksi dapat diperkirakan dari diferensial seleksi. Diferensial seleksi merupakan selisih antara rata-rata populasi terseleksi dengan rata-rata populasi awal pada generasi yang sama. Diferensial seleksi menunjukan superioritas dari individu-individu yang terpilih dibandingkan populasi dasarnya.

Karakter kuantitatif dikendalikan secara poligenik sehingga seleksi akan efektif dilakukan pada generasi lanjut atau pada saat persentase homozigositasnya sudah tinggi untuk mendukung pengembangan varietas tanaman menyerbuk sendiri (Aquaah 2007). Galur murni adalah salah satu bentuk varietas tanaman menyerbuk sendiri yang dikembangkan dari satu tanaman homozygot dan ditanam kembali dengan membiarkannya menyerbuk sendiri. Galur murni yang diinginkan dalam peneltian ini adalah galur murni yang memiliki daya hasil tinggi.

Hasil penelitian ini menunjukan bahwa karakter agronomi yang diamati pada populasi RILs F5 memiliki nilai ragam dalam galur lebih rendah dari ragam antar galur (Tabel 15). Hal ini mengindikasikan setiap galur F5 sebagian besar sudah seragam dalam galurnya dan beragam antar RILs F5. Karakter tinggi tanaman, bobot malai, dan bobot biji malai ${ }^{-1}$ merupakan karakter yang memiliki ragam antar galur yang tinggi dibandingkan karakter agronomi lainnya yang mengindikasikan antar RILs F5 memiliki penampilan yang sangat beragam terutama pada karakter tinggi tanaman, bobot malai, dan bobot biji malai ${ }^{-1}$. Informasi ini penting untuk mendapatkan galur sorgum berdaya hasil tinggi dengan tinggi tanaman yang rendah pada populasi RILs F5, disamping itu ragam dalam galur lebih rendah dibandingkan ragam antar galur pada penelitian ini memiliki peluang untuk menghasilkan galur murni yang potensial (Aquaah 2007).

Tabel 15. Nilai tengah, ragam dalam galur, dan ragam antar galur 201 RIL F5 sorgum

\begin{tabular}{|c|c|c|c|}
\hline Karakter & $\overline{\mathrm{Xi}}+\mathrm{Sd}$ & $\sigma_{\text {Rdg }}^{2}$ & $\sigma_{\mathrm{Rag}}^{2}$ \\
\hline Laju pengisian biji $\left(\mathrm{g} \mathrm{hari}^{-1}\right)$ & $1.4 \pm 0.5$ & 0.1 & 0.2 \\
\hline Tinggi tanaman $(\mathrm{cm})$ & $217.1 \pm 23.0$ & 272.9 & 530.9 \\
\hline Diameter batang $(\mathrm{mm})$ & $13.8 \pm 2.1$ & 2.8 & 4.2 \\
\hline Jumlah daun (helai) & $10.3 \pm 1.2$ & 0.8 & 1.3 \\
\hline Panjang malai $(\mathrm{cm})$ & $18.5 \pm 2.7$ & 2.3 & 7.6 \\
\hline Lingkar malai $(\mathrm{cm})$ & $14.9 \pm 1.9$ & 1.9 & 3.5 \\
\hline Bobot malai (g) & $62.4 \pm 20.5$ & 149.0 & 421.9 \\
\hline Bobot biji malai $^{-1}(\mathrm{~g})$ & $55.2 \pm 17.2$ & 96.6 & 296.4 \\
\hline
\end{tabular}

Berdasarkan penelitian ini maka dilakukanlah seleksi untuk memilih galurgalur terbaik. Menurut Wirnas et al. (2006); Sarwar, et al. (2004) seleksi langsung 
terhadap daya hasil dapat menghasilkan perbaikan yang besar apabila karakter hasil memiliki heritabilitas yang tinggi. Berdasarkan hal tersebut bobot biji malai ${ }^{-1}$ pada populasi RILs F5 efektif digunakan sebagai karakter seleksi karena memiliki keragaman genetik yang luas dan nilai heritabilitas yang tergolong tinggi dibanding karakter hasil lainnya. Hasil yang sama dilaporkan oleh Chavan et al. (2010); Rani \& Umakanth (2012); Sami et al. (2013b).

Seleksi langsung berdasarkan karakter tunggal yaitu bobot biji malai ${ }^{-1}$ dengan intensitas seleksi $15 \%$, nilai ragam dalam galur yang rendah dan nilai tengah yang lebih tinggi dari kedua tetua menghasilkan 30 galur terpilih. Seleksi ini dapat meningkatkan bobot biji malai ${ }^{-1} 35.3 \%$, bobot malai $37.7 \%$, lingkar malai $12 \%$, panjang malai $9.2 \%$, jumlah daun $1 \%$, tinggi tanaman $5 \%$, diameter batang $12.3 \%$, laju pengisian biji $21.4 \%$ periode pengisan biji $8.6 \%$, umur panen $0.6 \%$. dan menurunkan umur berbunga $4.4 \%$ (Tabel 16). Hal ini menyebabkan peningkatan secara umum karakter agronomi dan hasil.

Tabel 16. Nilai diferensial seleksi berdasarkan bobot biji malai ${ }^{-1}$ sorgum

\begin{tabular}{lrrr}
\hline Karakter & $\begin{array}{c}\text { Rata-rata } \\
\text { populasi awal }\end{array}$ & $\begin{array}{c}\text { Rata-rata populasi } \\
\text { terseleksi }\end{array}$ & $\begin{array}{r}\text { Diferensial } \\
\text { seleksi (\%) }\end{array}$ \\
\hline Umur berbunga (hari) & 64.3 & 61.5 & -4.4 \\
Umur panen (hari) & 103.8 & 104.4 & 0.6 \\
Periode pengisian biji (hari) & 39.5 & 42.9 & 8.6 \\
Laju pengisian biji (g hari $^{-1}$ ) & 1.4 & 1.7 & 21.4 \\
Diameter batang (mm) & 13.8 & 15.5 & 12.3 \\
Tinggi tanaman (cm) & 217.1 & 227.9 & 5.0 \\
Jumlah daun (helai) & 10.3 & 10.4 & 1.0 \\
Panjang malai (cm) & 18.5 & 20.2 & 9.2 \\
Lingkar malai (cm) & 14.9 & 16.7 & 12.1 \\
Bobot malai (g) & 62.4 & 85.9 & 37.7 \\
Bobot biji malai ${ }^{-1}(\mathrm{~g})$ & 55.2 & 74.7 & 35.3 \\
\hline
\end{tabular}

Seleksi tunggal merupakan seleksi yang dilakukan berdasarkan satu karakter yaitu karakter bobot biji malai ${ }^{-1}$ dengan tujuan memperoleh galur-galur berdaya hasil tinggi. Kelemahan seleksi berdasarkan karakter tunggal yaitu hanya lebih fokus pada satu karakter yang menjadi tujuan perbaikan seleksi tanpa memperhatikan pengaruh dari karakter lain. Hasil penelitian ini menunjukan bahwa akibat seleksi tunggal pada populasi terseleksi RILs F5 terjadi peningkatan nilai tengah tinggi tanaman sebesar $227.9 \mathrm{~cm}$ yang melebihi nilai tengah tinggi tanaman tetua Numbu sebesar $224.0 \mathrm{~cm}$. Hasil ini sesuai dengan penelitian Puspitasari (2011) dan Isnaini (2010). Peningkatan tinggi tanaman ini disebabkan oleh adanya korelasi yang positif antara bobot biji malai ${ }^{-1}$ dan tinggi tanaman sehingga seleksi berdasarkan bobot biji malai ${ }^{-1}$ tidak dapat diarahkan kepada perbaikan karakter tinggi tanaman.

Peningkatan tinggi tanaman tidak dibutuhkan dalam pengembangan sorgum sebagai bahan pangan. Tanaman yang tinggi dapat mengakibatkan meningkatkanya resiko rebah batang dan sulitnya dalam pemanenan maupun pemeliharaan (Sungkono 2010). Disamping itu karakter tinggi tanaman pada penelitian ini dapat dijadikan sebagai karakter seleksi karena memiliki nilai heritabilitas yang tinggi, keragaman genetik yang luas, dan ragam antar galur yang 
tinggi. Oleh karena itu seleksi berdasarkan dua karakter yaitu bobot biji malai ${ }^{-1}$ dan tinggi tanaman untuk mengatasi resiko rebah batang efektif untuk dilakukan.

Seleksi langsung berdasarkan dua karakter yaitu bobot biji malai ${ }^{-1}$ dan tinggi tanaman berdasarkan nilai ragam dalam galur yang rendah, bobot biji malai ${ }^{1}$ yang lebih tinggi dari kedua tetua dan tinggi tanaman lebih rendah dari tetua Numbu menghasilkan 20 galur terpilih. Hasil seleksi ini menyebabkan peningkatan diferensial seleksi bobot biji malai ${ }^{-1} 21.0 \%$ bobot malai $16.0 \%$, lingkar malai $5.4 \%$, panjang malai $12.4 \%$, diameter batang $3.6 \%$, laju pengisian biji $7.1 \%$, periode pengisan biji $9.6 \%$, dan umur panen $1.5 \%$. Seleksi dua karakter dapat menurunkan umur berbunga $3.4 \%$, jumlah daun $6.8 \%$, dan tinggi tanaman $6.9 \%$ (Tabel 17). Hal ini berarti seleksi berdasarkan bobot biji malai ${ }^{-1}$ dan tinggi tanaman menyebabkan peningkatan bobot biji malai ${ }^{-1}$ dengan tinggi tanaman yang lebih rendah dibandingkan tetua Numbu pada populasi terseleksi.

Tabel 17. Nilai diferensial seleksi berdasarkan bobot biji malai ${ }^{-1}$ dan tinggi tanaman sorgum

\begin{tabular}{|c|c|c|c|}
\hline Karakter & $\begin{array}{c}\text { Rata-rata } \\
\text { populasi awal }\end{array}$ & $\begin{array}{c}\text { Rata-rata populasi } \\
\text { terseleksi }\end{array}$ & $\begin{array}{l}\text { Diferensial } \\
\text { seleksi (\%) }\end{array}$ \\
\hline Umur berbunga (hari) & 64.3 & 62.1 & -3.4 \\
\hline Umur panen (hari) & 103.8 & 105.4 & 1.5 \\
\hline Periode pengisian biji (hari) & 39.5 & 43.3 & 9.6 \\
\hline Laju pengisian biji (g hari-1 $)$ & 1.4 & 1.5 & 7.1 \\
\hline Diameter batang (mm) & 13.8 & 14.3 & 3.6 \\
\hline Tinggi tanaman $(\mathrm{cm})$ & 217.1 & 202.2 & -6.9 \\
\hline Jumlah daun (helai) & 10.3 & 9.6 & -6.8 \\
\hline Panjang malai $(\mathrm{cm})$ & 18.5 & 20.8 & 12.4 \\
\hline Lingkar malai $(\mathrm{cm})$ & 14.9 & 15.7 & 5.4 \\
\hline Bobot malai (g) & 62.4 & 72.6 & 16.3 \\
\hline Bobot biji malai $^{-1}(\mathrm{~g})$ & 55.2 & 66.8 & 21.0 \\
\hline
\end{tabular}

Seleksi langsung berdasarkan bobot biji malai ${ }^{-1}$ dan tinggi tanaman menyebabkan peningkatkan bobot biji malai ${ }^{-1}$ lebih rendah dibanding seleksi berdasarkan bobot biji malai ${ }^{-1}$ (Tabel 16 dan 17). Hal ini disebabkan karena tinggi tanaman berkorelasi positif dan nyata terhadap bobot biji malai ${ }^{-1}$ artinya tanaman yang tinggi pada penelitian ini cenderung memiliki bobot biji malai ${ }^{-1}$ yang lebih tinggi. Hal tersebut bertolak belakang dengan tujuan seleksi yang dilakukan dimana galur terseleksi harus memiliki daya hasil yang tinggi namun tinggi tanaman lebih rendah dibanding tetua Numbu.

Keragaan fenotipik 20 RIL F5 terpilih berdasarkan bobot biji malai ${ }^{-1}$ dan tinggi tanaman ditunjukan pada Tabel 18. Galur-galur terpilih kemudian di uji lanjut dengan uji-t untuk melihat perbedannya dengan Varietas Numbu, Samurai1, Samurai-2, dan B69. Karakter vegetatif seperti tinggi tanaman, diameter batang, dan jumlah daun pada populasi RILs F5 berbeda nyata dengan Numbu, B69, Samurai-1, dan Samurai-2. Laju pengisian biji pada populasi RIL F5 berbeda nyata dengan Numbu, Samurai-1, Samurai-2, dan B69. Karakter hasil seperti panjang malai, lingkar malai, bobot malai dan bobot biji malai ${ }^{-1}$ pada populasi RIL F5 berbeda nyata dengan keempat varietas pembanding yang digunakan. Hal ini berarti bahwa galur-galur terpilih dari persilangan B69 x Numbu memliki daya hasil lebih tinggi dari varietas kontrol yang digunakan. 


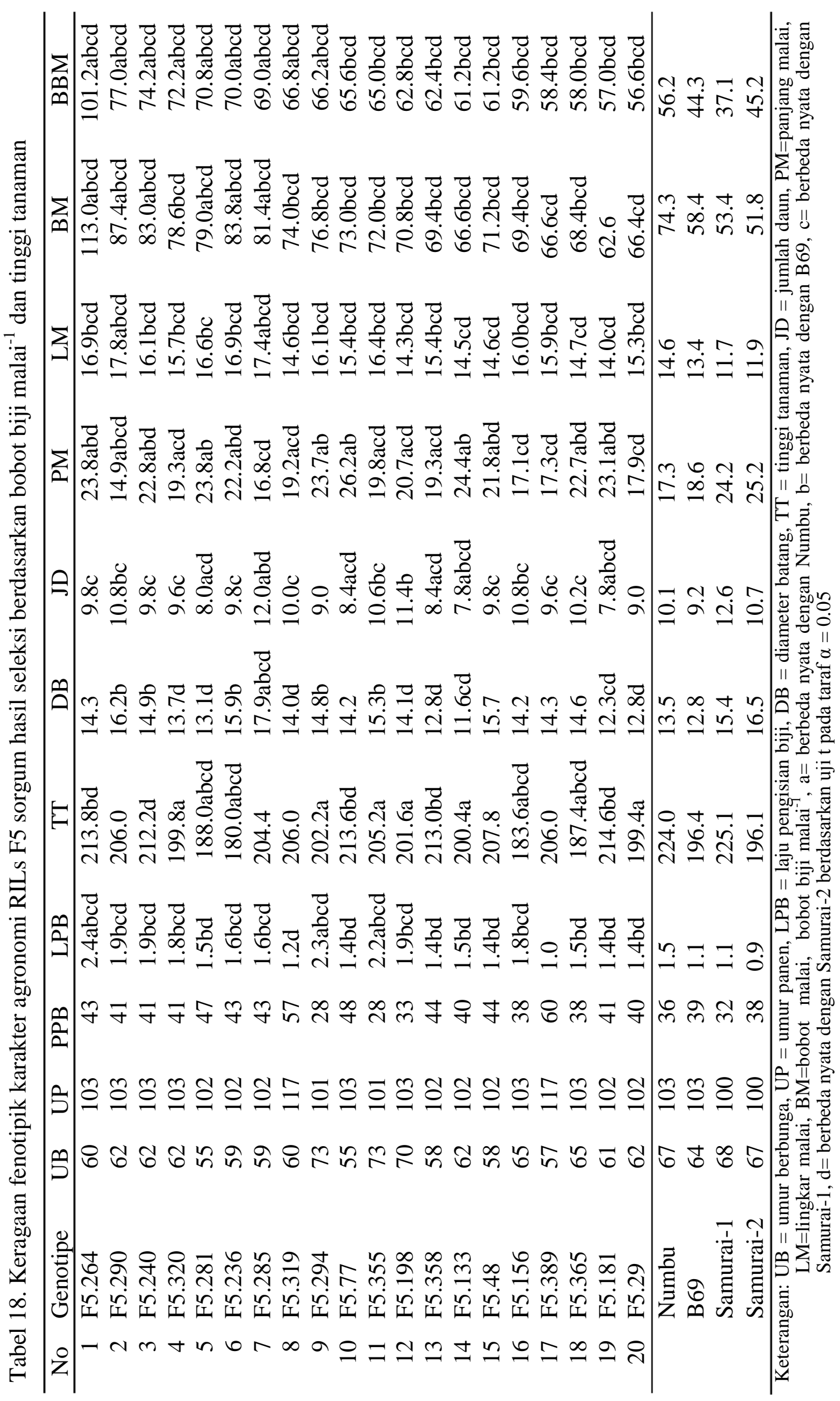




\section{Deskripsi Sepuluh RILs F5 Sorgum Hasil Seleksi Berdasarkan Bobot Biji per Malai dan Tinggi Tanaman}

Galur-galur pada penelitian ini merupakan RILs F5 hasil persilangan antara B69 dengan Numbu hasil penggaluran dengan metode single seed descent. Rekombinant Inbred Lines (RILs) merupakan individu - individu hasil persilangan yang mengalami peneyerbukan sendiri selama beberapa generasi dan tidak dilakukan kegiatan seleksi pada generasi sebelumnya. RILs F5 hasil seleksi langsung berdasarkan bobot biji malai ${ }^{-1}$ dan tinggi tanaman memiliki ragam dalam galur yang rendah, tinggi tanaman yang rendah, dan bobot biji malai ${ }^{-1}$ yang tinggi dibandingkan tetua Numbu menghasilkan 20 galur terpilih. RILs F5 terpilih memiliki karakteristik tersendiri terhadap karaker yang dimiliki.

Hoeman (2011); House (1985) melaporkan bahwa tipe sorgum ideal (plant-idiotipe) yang berdaya hasil tinggi dan sesuai untuk dijadikan sebagai tanaman pangan yaitu; memiliki umur berbunga genjah (56-65 hari), umur panen sedang sampai dalam (100-120 hari), tinggi tanaman tergolong rendah sampai sedang (151-200 cm), batang tidak mudah rebah, dan bobot biji malai ${ }^{-1}$ yang tinggi. Berdasarkan tipe pengelompokan tersebut maka terdapat 10 RILs F5 hasil seleksi langsung berdasarkan bobot biji malai ${ }^{-1}$ dan tinggi tanaman yang sesuai dengan kriteria tersebut yaitu RILs F5.264, F5.290, F5.240, F5.281, F5.236, F5.156, F5.365, F5.285, dan F5.294, F5.355 (Tabel 18).

\section{RILs F5.264}

RILs F5.264 memiliki laju pengisian biji, bobot malai, dan bobot biji malai $^{-1}$ yang nyata lebih tinggi dibandingkan empat varietas kontrol. Tinggi tanaman RILs F5.264 dikategorikan lebih mendekati tinggi tanaman ideal (151200). Meskipun tinggi tanaman dikategorikan sedikit lebih tinggi dari tipe tanaman ideal namun kondisi di lapang memperlihatkan bahwa RILs F5.264 tahan akan kerebahan. Menurut deskripsi pengelompokan umur berbunga dan umur panen sorgum yang dilakukan oleh Elangovan (2014) diketahui bahwa galur RILs F5.264 memiliki umur berbunga yang tergolong genjah dengan umur panen yang tergolong dalam. Keunggulan yang paling menonjol dari galur RILs F5.264 yaitu memiliki bobot biji malai ${ }^{-1}$ yang lebih sangat tinggi dibandingkan keempat varietas kontrol maupun RILs F5 terseleksi lainnya. Menurut hasil penelitian Zevacevic et al. (2010) galur yang memiliki bobot biji malai ${ }^{-1}$ yang tinggi akan meningkatkan indeks panen dan potensi hasil dari suatu tanaman sehingga RILs F5.264 dapat direkomendasikan untuk dilakukan uji daya hasil dengan ciri khas memiliki bobot biji malai ${ }^{-1}$ yang tinggi sehingga dapat meningkatkan potensi hasil sorgum untuk kebutuhan pangan.

\section{RILs F5.285}

RILs F5.285 memiliki diameter batang, lingkar malai, bobot malai, dan bobot biji malai ${ }^{-1}$ berbeda nyata lebih tinggi dibandingkan empat varietas kontrol. Tinggi tanaman RILs F5.285 dikategorikan lebih mendekati tinggi tanaman ideal meskipun tinggi tanaman ini dikategorikan sedikit lebih tinggi dari tipe tanaman ideal kondisi di lapang memperlihatkan tahan akan kerebahan. Menurut deskripsi pengelompokan umur berbunga dan umur panen sorgum yang dilakukan oleh Elangovan (2014) diketahui bahwa F5.285 memiliki umur berbunga yang 
tergolong genjah dengan umur panen yang tergolong dalam. Keunggulan yang menonjol dari RILs F5.285 yaitu memiliki diameter batang yang lebih besar dibandingkan keempat varietas kontrol maupun RILs F5 terseleksi. Menurut penelitian Tsuchihashi dan goto (2008) galur yang memiliki diameter batang yang besar $(16-25 \mathrm{~mm})$ disamping bermanfaat untuk mengurangi resiko rebah batang juga memiliki kemampuan ratoon yang baik sehingga dapat dipanen 2 sampai 3 kali dengan hasil biji yang tidak jauh berbeda. Menurut Efendi et al. (2013) dengan memanfaatkan ratun maka budidaya sorgum akan menjadi lebih efisien karena dapat mengurangi biaya tenaga kerja, waktu untuk tanam dan pengolahan tanah serta penggunaan benih. RILs F5.285 dapat direkomendasikan untuk dilakukan uji daya hasill dengan ciri khas diameter batang yang besar dengan daya hasil tinggi serta memiliki kemampuan ratun yang baik.

\section{RILs F5.281, F5.236, F5.156, dan F5.365}

RILs F5.281 dan F5.236 memiliki bobot malai dan bobot biji malai ${ }^{-1}$ yang nyata lebih tinggi sementara pada karakter tinggi tanaman berbeda nyata lebih rendah dibandingkan empat varietas kontrol. Galur F5.156 dan F5.365 memiliki lingkar malai, bobot malai dan bobot biji malai ${ }^{-1}$ yang nyata lebih tinggi dari 3 varietas kontrol. Tinggi tanaman keempat RILs memiliki tinggi tanaman yang ideal, disamping itu kondisi di lapang juga memperlihatkan bahwa keempat RILs tersebut tahan akan kerebahan. Menurut deskripsi pengelompokan umur berbunga dan umur panen sorgum yang dilakukan oleh Elangovan (2014) diketahui bahwa keempat galur memiliki umur berbunga yang tergolong genjah dengan umur panen yang tergolong dalam. Keunggulan yang paling menonjol dari keempat RILs yaitu memiliki tinggi tanaman yang tergolong lebih rendah dibandingkan keempat varietas kontrol maupun RILs F5 terseleksi lainnya. Menurut Aquaah (2007) galur sorgum yang memiliki keragaan tinggi tanaman yang rendah maka akan mengurangi resiko rebah batang, memudahkan dalam pemeliharaan maupun pengendalian terhadap serangan hama dan penyakt, serta secara tidak langsung dapat meningkatkan hasil biji karena alokasi fotosintat akan lebih banyak ke biji sehingga keempat RILs dapat direkomendasikan untuk dilakukan uji daya hasill dengan ciri khas tinggi tanaman yang rendah.

\section{RILs F5.240}

RILs F5.240 memiliki bobot malai dan bobot biji malai ${ }^{-1}$ yang nyata lebih tinggi dibandingkan empat varietas kontrol. Tinggi tanaman RILs F5.240 dikategorikan mendekati tinggi tanaman ideal, meskipun tinggi tanaman ini dikategorikan sedikit lebih tinggi dari tipe tanaman ideal namun kondisi di lapang juga memperlihatkan bahwa RILs F5.240 tahan akan kerebahan. Menurut deskripsi pengelompokan umur berbunga dan umur panen sorgum yang dilakukan oleh Elangovan (2014) diketahui bahwa RILs F5.240 memiliki umur berbunga yang tergolong genjah dengan umur panen yang tergolong dalam. Keunggulan yang paling menonjol dari galur RILs F5.240 yaitu memiliki panjang malai yang lebih besar dibandingkan kedua varietas pembanding maupun galur F5 terseleksi sehingga dapat direkomendasikan untuk dilakukan uji daya hasil dengan ciri khas malai yang panjang. Menurut House (1985) galur yang memiliki malai yang panjang akan memberikan peluang untuk biji sorgum tumbuh sangat banyak pada galur tersebut sehingga dapat meningkatkan potensi hasil sorgum untuk kebutuhan pangan. 


\section{RILs F5.294 dan F5.355}

RILs F5.294 dan F5.355 memiliki lingkar malai, bobot malai dan bobot biji malai $^{-1}$ yang nyata lebih tinggi dibandingkan tiga varietas kontrol namun memiliki laju pengisian biji yang lebih tinggi dibandingkan empat varietas kontrol. Tinggi tanaman RILs F5.294 dan F5.355 dikategorikan mendekati tinggi tanaman ideal, meskipun tinggi tanaman ini dikategorikan sedikit lebih tinggi dari tipe tanaman ideal namun kondisi di lapang memperlihatkan bahwa kedua galur tahan akan kerebahan. Menurut deskripsi pengelompokan umur berbunga dan umur panen sorgum yang dilakukan oleh Elangovan (2014) diketahui bahwa kedua galur memiliki umur berbunga yang tergolong sedang dengan umur panen yang tergolong dalam. Keunggulan yang paling menonjol dari RILs F5.294 dan F5.355 yaitu memiliki laju pengisian biji yang tinggi serta memiliki periode pengisan biji yang lebih singkat dibandingkan keempat varietas kontrol maupun RILs F5 terseleksi lainya. Menurut Naserian et al. (2007) laju pengisian biji yang tinggi mengakibatkan semakin besar asimilat yang ditranslokasikan ke biji sorgum sehingga bobot biji sorgum menjadi meningkat. Laju pengisian biji dipengaruhi oleh bobot biji malai ${ }^{-1}$ dan periode pengisian biji, artinya semakin tinggi laju pengisian biji maka akan menyebabkan peningkatan terhadap bobot biji malai ${ }^{-1}$ serta akan mempersingkat masa periode pengisian biji suatu tanaman yang berujung umur panen menjadi lebih pendek (House 1985). Hal ini sesuai dengan RILs F5.294 dan RILs.355 dimana laju pengisian yang tinggi disamping mengakibatkan daya hasil menjadi tinggi juga mengakibatkan umur panen dari tanaman menjadi lebih singkat dibandingkan galur F5 terseleksi sehingga laju pengisan biji dapat dijadikan sebagai perkiraan yang baik untuk menghasilkan galur sorgum berdaya hasil tinggi dan memiliki umur panen menjadi pendek. Berdasarkan hal tersebut RILs F5.294 dan F5.355 dapat direkomendasikan untuk dilakukan uji daya hasil dengan ciri khas laju pengisian biji yang tinggi.

\section{RILs F5.290}

RILs F5.290 yang diuji pada penelitian ini memiliki lingkar malai, bobot malai, dan bobot biji malai ${ }^{-1}$ yang nyata lebih tinggi sedangkan pada karakter panjang malai nyata lebih rendah dibandingkan empat varietas pembanding. Hal ini mengindikasikan penampilan panjang malai RILs F5.290 lebih pendek namun memiliki lingkar malai, bobot malai, dan bobot biji malai ${ }^{-1}$ yang lebih tinggi dibanding keempat varietas kontrol. Tinggi tanaman RILs F5.290 dikategorikan lebih mendekati tinggi tanaman ideal $(151-200 \mathrm{~cm})$, meskipun tinggi tanaman ini dikategorikan sedikit lebih tinggi dari tipe tanaman ideal namun kondisi di lapang memperlihatkan bahwa RILs F5.290 tahan akan kerebahan. Menurut deskripsi pengelompokan umur berbunga dan umur panen sorgum yang dilakukan oleh Elangovan (2014) diketahui bahwa F5.290 memiliki umur berbunga yang tergolong genjah dengan umur panen yang tergolong dalam. Keunggulan yang paling menonjol dari galur F5.290 yaitu memiliki lingkar malai yang lebih besar dan nyata dibandingkan keempat varietas kontrol maupun galur F5 terseleksi lainya sehingga dapat direkomendasikan untuk dilakukan uji daya hasil pada RILs F5.290 dengan ciri khas lingkar malai yang besar sehingga dapat meningkatkan potensi hasil sorgum. 


\section{Simpulan}

RILs F5 sorgum hasil persilangan B69 x Numbu menunjukan keragaan karakter kuantitatif yang berbeda nyata antar galur pada karakter periode pengisian biji, tinggi tanaman, jumlah daun, panjang malai, lingkar malai, bobot malai, dan bobot biji malai ${ }^{-1}$. Karakter periode pengisian biji, tinggi tanaman, jumlah daun, panjang malai, lingkar malai, bobot malai, dan bobot biji malai ${ }^{-1}$ memiliki heritabilitas tinggi dan keragaman genetik yang luas. Karakter tinggi tanaman, panjang malai, lingkar malai, bobot malai, dan bobot biji malai ${ }^{-1}$ dapat digunakan sebagai karakter seleksi. Terdapat RILs F5 yang mempunyai daya hasil lebih tinggi dari kedua tetua dan memliki ragam dalam galur yang rendah. Seleksi langsung berdasarkan dua karakter sekaligus lebih efektif dibandingkan seleksi satu karakter untuk meningkatkan daya hasil dan menurunkan tinggi tanaman. Keragaan karakter agronomi dari 20 galur hasil seleksi berdasarkan bobot biji malai ${ }^{-1}$ dan tinggi tanaman bervariasi dimana secara umum galur-galur terpilih memiliki bobot biji malai ${ }^{-1}$ lebih tinggi dan tinggi tanaman lebih rendah dibandingkan tetua Numbu 


\section{PEMBAHASAN UMUM}

Sorgum (Sorghum bicolor (L.) Moench) merupakan tanaman pangan penting kelima di dunia setelah padi, gandum, jagung dan barley (Reddy et al. 2012). Tanaman ini merupakan kelompok tanaman menyerbuk sendiri yang memiliki konstitusi homogen homozigot dalam satu populasi dan homogen heterozigot antar populasi. Daerah asal tanaman sorgum baik spesies liar maupun spesies budidaya ditemukan di Afrika. Hingga saat ini 90\% luas lahan pertanaman berada di wilayah Afrika dan Asia (Acquaah 2007).

Perakitan varietas sorgum berdaya hasil tinggi telah dilakukan di Indonesia dengan menyilangkan genotipe-genotipe hasil persilangan, mutasi maupun introduksi. Departemen Agronomi dan Hortikultura, Fakultas Pertanian, Institut Pertanian Bogor telah melakukan persilangan B69 x Numbu dan menghasilkan populasi RILs F5 hasil metode penggaluran single seed descent. Hingga saat ini dari persilangan yang dilakukan antara galur B69 dan vaeietas Numbu telah menghasilkan 201 RIL F5. Pemilihan galur sebagai tetua persilangan dilakukan berdasarkan informasi keragaan dan daya hasil galur tersebut. Menurut Balitsereal (2014) Numbu merupakan varietas nasional yang toleran tanah masam dan memiiki potensi hasil 4-5 ton $\mathrm{ha}^{-1}$. B69 merupakan galur mutan hasil radiasi sinar gamma yang berasal varietas Dura yang tahan kekeringan dengan tinggi tanaman yag relatif rendah dan memiliki potensi hasil 2.14 ton ha ${ }^{-1}$ (Sungkono 2010).

Penampilan kedua tetua dan daya gabung keduanya akan menentukan arah pemuliaan tanaman yang sesuai (Bawazir 2009). Berdasarkan penelitian sebelumnya yang dilakukan oleh Rini (2014) diketahui bahwa dari berbagai evaluasi persilangan yang dilakukan, generasi F1 hasil persilangan B69 x Numbu merupakan kombinasi persilangan terbaik untuk karakter hasil. Hal ini disebabkan karena kedua tetua memiliki daya gabung umum dan khusus yang tinggi serta nilai heterosis yang lebih tinggi dbandingkan generasi F1 hasil persilangan lainnya. Generasi F2 hasil persilangan B69 x Numbu yang dilakukan Sulistyowati (2015) menunjukan bahwa seluruh karakter agronomi dan hasil yang diamati memiliki sebaran normal, bersifat poligenik dengan aksi gen aditif sehingga seleksi akan efektif dilakukan pada generasi lanjut pada saat fiksasi gen aditifnya yang bersifat poligeneik sudah semakin baik. Hal ini mengindikasikan terdapat potensi yang diinginkan pemulia untuk menghasilkan varietas unggul sorgum berdaya hasil tinggi melalui persilangan B69 x Numbu dengan metode penggaluran single seed descent.

Metode single seed descent merupakan salah satu metode penggaluran pada tanaman menyerbuk sendiri. Metode ini digunakan untuk mengembangkan galur murni superior dan telah berhasil digunakan pada tanaman seperti sereal, kedelai, tomat, selada, dan safflower. Kelebihan metoda single seed descent adalah; keperluan lahan lebih sempit karena benih yang ditanam satu biji dari setiap tanaman, pencatatan dan pengamatan jauh lebih sederhana, dimungkinkan untuk menanam sejumlah generasi tiap tahun melalui pengendalian lingkungan, misalnya dalam rumah kaca. Kelemahan metoda single seed descent adalah; identitas unggul dari generasi F2 tidak diketahui, bila pemilihan sejak awal generasi tidak jeli dan kurang tajam maka dapat mengakibatkan hilangnya beberapa individu tanaman yang superior karena pemilihan hanya berdasarkan satu tanaman tunggal (Chahal \& Gosal 2003). 
Berdasarkan hasil penelitian keragaan dan keragaman karakter agronomi sorgum populasi $\mathrm{F} 4$, diperoleh bahwa semua karakter yang diamati memiliki nilai heritabilitas tergolong tinggi dengan keragaman genetik yang tergolong sedang sampai luas. Hal ini mengindikasikan bahwa metode single seed descent dapat mempertahankan nilai heritailitas dan keragaman genetik sampai generasi lanjut. Hal ini sesuai dengan penelitian Sihaloho (2015) dimana populasi kedelai F3 ke F4 menggunakan metode single seed descent telah berhasil mempertahankan nilai heritabilitas dan keragaman genetik. Hal ini disebabkan latar belakang genetik antara yang luas antara kedua tetua kemudian keragaman genetik yang luas tersebut dipertahankan dengan metode single seed descent dimana setiap galur diwakili satu individu sampai mencapai keseragaman pada generasi lanjut (F5/F6)

RILs F5 menunjukan perbedaan keragaan pada karakter periode pengisian biji, tinggi tanaman, jumlah daun, panjang malai, lingkar malai, bobot malai, dan bobot biji malai ${ }^{-1}$. Keragaman genetik luas dan heritabilitas tinggi terdapat pada karakter periode pengisian biji, tinggi tanaman, jumlah daun, panjang malai, lingkar malai, bobot malai, dan bobot biji malai ${ }^{-1}$. Sejumlah galur F5 yang memiliki nilai lebih baik dari tetuanya, yaitu: 99 galur untuk umur berbunga < 64 HST, 72 galur untuk umur panen $<103.0$ HST, 55 galur untuk periode pengisian biji < 36 hari, 67 galur untuk laju pengisian biji $>1.5$ gr hari ${ }^{-1}$, 36 galur untuk tinggi tanaman $<196.4 \mathrm{~cm}, 118$ galur untuk diameter batang $>13.5 \mathrm{~mm}$, 86 galur untuk jumlah dan $>10$, 90 galur untuk panjang malai $>18.6 \mathrm{~cm}, 110$ galur untuk lingkar malai $>14.6 \mathrm{~cm}, 57$ galur untuk bobot malai $>74.3$ gr, 94 galur untuk bobot biji malai ${ }^{-1}>56.2$.

Karakter yang memiliki keragaman genetik luas dan heritabilitas tinggi pada generasi lanjut RILs F5 hasil SSD dari persilangan di antara B69 x Numbu mengindikasikan bahwa karakter tersebut dipengaruhi oleh gen-gen aditif. Menurut Mangoendidjojo (2003) populasi hasil penggaluran single seed descent tidak dilakukan seleksi pada generasi awal sehingga dengan membiarkan setiap individu menyerbuk sendiri, maka gen-gen aditif akan terfiksasi lebih baik pada generasi lanjut. Hal ini menyebabkan nilai $\mathrm{h}^{2}$ bs merupakan perkiraan yang baik dari besarnya $\mathrm{h}^{2}$. Menurut Falconer dan Mackay (1996) heritabilitas yang tinggi bermanfaat dalam seleksi jika ragam genetik didominasi oleh ragam aditif, karena pengaruh aditif setiap alel akan diwariskan dari tetua pada turunannya.

Metode single seed descent dapat mempertahankan keragaman genetik yang luas pada generasi awal sampai generasi lanjut serta meningkatkan jumlah segregan transgresif sebelum dilakukan seleksi. Penelitian ini membuktikan bahwa populasi F5 hasil single seed descent sebagian besar karakter agronomi yang diamati memiliki keragaman genetik yang luas dan jumlah segregan transgresif pada populasi F5 mengalami peningkatan dibandingkan populasi F4. Hal ini disebabkan karena metode single seed descent pada prinsipnya setiap indivdu di generasi awal tetap dipertahankan sampai mencapai tingkat keseragaman yang diinginkan sebelum dilakukan seleksi pada generasi lanjut (F5/F6) sehingga tidak terjadi perubahan frekuensi gen tetapi hanya mengubah frekuensi genotipe dimana frekuensi genotipe homozigot akan meningkat, sedangkan frekuensi genotipe heterozigot menurun oleh karena itu pada generasi lanjut F5 proporsi homozigot sudah semakin tinggi yang menyebabkan segregan transgresif pada populasi F5 menjadi meningkat dibandingkan populasi sebelumnya. Seleksi pada populasi F5 dapat dilakukan karena pada generasi 
tersebut gen aditif telah terfiksasi dengan baik, sehingga pada generasi ini proporsi homozigositas yang menyusun karakter agronomi telah tinggi $( \pm 95 \%)$ (Riaz \& Chowdhry, 2003; Santoso, 2007).

Galur-galur pada populasi F5 hasil metode bulk tidak terlalu disting perbedaan antar galurnya karena pada proses metode bulk kemungkinan akan terpilih biji dari malai yang sama akan besar karena pada setiap generasi akan dicampur atau di bulk kembali. Galur-galur pada populasi F5 hasil metode pedigree sangat rendah perbedaan antar galurnya karena pada proses metode pedigree seleksi dilakukan pada generasi awal sehingga pada generasi F5 hanya galur-galur yang sesuai dengan kriteria seleksi saja yang tetap dipertahankan. Galur- galur pada populasi F5 hasil metode single seed descent sangat disting perbedaan antar galurnya dimana keragaman yang luas pada generasi awal dapat dipertahankan keragaman masing-masing galurnya karena setiap galur dari generasi awal tetap dipertahankan keberadaannya sampai generasi lanjut (F5). Hal inilah yang menyebabkan perbedaan antara metode penggaluran bulk, pedigree, dan single seed descent pada populasi F5.

Berdasarkan hasil analisis korelasi dan analisis lintas yang dilakukan pada percobaan ini telah diketahui hubungan sepuluh karakter agronomi dengan karakter bobot biji malai ${ }^{-1}$. Hubungan karakter tersebut menjadi dasar dalam menyusun karakter seleksi. Karakter - karakter yang dapat digunakan sebagai karakter seleksi memiliki beberapa syarat yaitu (1) berkorelasi kuat terhadap karakter target, (2) memiliki heritabilitas yang tinggi, (3) mudah diamati secara visual (Roy 2000). Hal ini ditambahkan Natawijaya (2012) dimana karakter yang berkorelasi kuat namun berpengaruh langsung rendah terhadap karakter bobot biji malai $^{-1}$ dapat dipertimbangkan sebagai karakter untuk menyusun kriteria seleksi dengan syarat nilai heritabilitasnya tinggi. Berdasarkan hal tersebut karakter tinggi tanaman, panjang malai, lingkar malai, bobot malai, dan bobot biji malai ${ }^{-1}$ dapat direkomendasikan sebagai karakter seleksi untuk perbaikan potensi hasil.

RILs F5 sebagian besar galur-galur populasi RILs F5 sudah seragam dalam galurnya. Hal ini dapat dilihat dari ragam dalam galur yang rendah dibandingkan ragam antar galur terhadap seluruh karakter agronomi yang diamati yang mengindikasikan bahwa fiksasi gen aditif pada RILs F5 sudah semakin baik. Berdasarkan hal tersebut seleksi pada RILs F5 adalah seleksi galur dimana galur yang memiliki keragaman dalam galur yang rendah dan memiliki nilai tengah yang lebih baik dari kedua tetua yang akan dilanjutkan untuk menghasilkan galur murni yang potensial. Hal ini disebabkan karena galur murni memiliki konstitusi genetik homogen homozigot artinya galur murni tersebut memiliki keragaman yang rendah dalam galurnya sehingga ketika ditanam diharapkan tidak menimbulkan keragaman lagi dalam galurnya.

Seleksi langsung berdasarkan karakter tunggal yaitu bobot biji malai ${ }^{-1}$ dengan intensitas seleksi $15 \%$, nilai ragam dalam galur yang rendah dan nilai tengah yang lebih tinggi dari kedua tetua menghasilkan 30 galur terpilih. seleksi berdasarkan bobot biji malai ${ }^{-1}$ dapat meningkakan secara umum karakter agronomi dan hasil termasuk karakter tinggi tanaman. Kelemahan seleksi berdasarkan karakter tunggal yaitu hanya lebih fokus pada satu karakter tanpa memperhatikan pengaruh dari berbagai karakter lain yang diamati. Akibat seleksi tunggal pada populasi terseleksi RIL F5 terjadi peningkatan nilai tengah tinggi tanaman $227.9 \mathrm{~cm}$ melebihi nilai tengah tinggi tanaman tetua Numbu $224.0 \mathrm{~cm}$. 
Peningkatan tinggi tanaman tidak dibutuhkan dalam pengembangan sorgum sebagai bahan pangan. Tanaman yang tinggi dapat mengakibatkan meningkatkanya resiko rebah batang dan sulitnya dalam pemanenan maupun pemeliharaan. Disamping itu karakter tinggi tanaman pada penelitian ini dapat dijadikan sebagai karakter seleksi karena memiliki nilai heritabilitas yang tinggi dan keragaman genetik yang luas. Oleh karena itu seleksi langsung berdasarkan dua karakter yaitu bobot biji malai ${ }^{-1}$ dan tinggi tanaman untuk mengatasi resiko rebah batang efektif untuk dilakukan.

Seleksi langsung berdasarkan bobot biji malai ${ }^{-1}$ dan tinggi tanaman berdasarkan nilai ragam dalam galur yang rendah, bobot biji malai ${ }^{-1}$ yang lebih tinggi dan tinggi tanaman lebih rendah dari tetua Numbu menghasilkan 20 galur terpilih. Seleksi berdasarkan bobot biji malai ${ }^{-1}$ dan tinggi tanaman menyebabkan peningkatan bobot biji malai ${ }^{-1}$ dengan tinggi tanaman yang lebih rendah dibandingkan tetua Numbu pada populasi terseleksi.

Seleksi langsung berdasarkan bobot biji malai ${ }^{-1}$ dan tinggi tanaman lebih rendah dalam meningkatkan daya hasil dibanding seleksi berdasarkan bobot biji malai $^{-1}$. Hal ini disebabkan tinggi tanaman berkorelasi positif dan nyata terhadap bobot biji malai ${ }^{-1}$ artinya tanaman yang tinggi pada penelitian ini cenderung memiliki bobot biji malai ${ }^{-1}$ yang lebih tinggi. Hal tersebut bertolak belakang dengan tujuan seleksi dimana galur terseleksi harus memiliki daya hasil yang tinggi namun tinggi tanaman lebih rendah dibanding tetua Numbu.. Peningkatan daya hasil tanpa diikuti peningkatan tinggi tanaman sangat mendukung dalam program pemuliaan tanaman sorgum sebagai sumber bahan pangan.

Hasil seleksi berdasarkan dua karakter sekaligus yakni bobot biji malai ${ }^{-1}$ dan tinggi tanaman pada populasi RILs F5 menghasilkan 20 benih RIL F6 yang memiliki potensi hasil tinggi. Galur-galur terseleksi ini diharapkan memilki fiksasi gen aditif yang tinggi sehingga tidak menimbulkan segregasi lagi didalam galurnya terutama pada karakter tinggi tanaman dan bobot biji malai ${ }^{-1}$. Benih RIL F6 yang terpilih kemudian bisa dilakukan uji daya hasil pendahuluan pada kondisi lingkungan yang optimum karena galur galur terpilih tersebut sebelumnya selalu ditanam pada kondisi lingkungan yang optimum dengan harapan agar gen-gen yang mengatur potensi hasil akan terekspresi dengan baik, disamping itu pada penelitian ini Populasi RILs F5 menghasilkan 201 benih RIL F6 yang dapat digunakan untuk studi genetik seperti analisis QTL yang bertujuan untuk mengetahui gen-gen atau sekuens tertentu dalam kromosom yang mengendalikan karakter kuantitatif kemudian 201 benih RIL F6 juga dapat digunakan untuk seleksi toleransi terhadap kondisi $\mathrm{P}$ rendah dan $\mathrm{P}$ tinggi menggunakan indeks tolerant. Hal ini disebabkan karena kedua tetua memiliki kemampuan yang berbeda terhadap toleransi P. Menurut penelitian Agustina (2011) menyatakan bahwa pada kultur hara Numbu termasuk efisien dalam penggunaan P, sedangkan B69 inefisien dalam penggunaan $P$. 


\section{SIMPULAN DAN SARAN}

\section{Simpulan}

Berdasarkan serangkaian penelitian yang dilakukan, maka dapat disimpulkan bahwa :

1. Metode single seed descent mampu mempertahankan keragaman genetik dan nilai heritabilitas yang tinggi serta menghasilkan segregan-segregan transgesif untuk karakter agronomi.

2. Karakter yang dapat dijadikan sebagai karakter seleksi pada populasi RILs F5 adalah bobot biji malai ${ }^{-1}$ bobot malai, lingkar malai, panjang malai, dan tinggi tanaman.

3. Seleksi berdasarkan bobot biji malai ${ }^{-1}$ dan tinggi tanaman pada populasi RILs F5 menghasilkan 20 galur terpilih yang memiliki ragam rendah, tinggi tanaman yang lebih rendah dan berdaya hasil tinggi dibandingkan tetua Numbu.

4. Metode single seed descent dapat dijadikan sebagai pilihan untuk komoditi sorgum dalam menghasilkan galur-galur harapan sorgum berdaya hasil tinggi.

\section{Saran}

Galur-galur yang berdaya hasil tinggi dan memiliki keragaman dalam galur yang rendah dapat dilanjutkan untuk uji lanjut daya hasil dengan menggunakan plot berulangan. 


\section{DAFTAR PUSTAKA}

Acquaah G. 2007. Principles of Plant Genetics and Breeding. United Kingdom (GB): Blackwell Publishing.

Agustina K, Sopandie D, Trikoesoemaningtyas, Wirnas D. 2010. Tanggap fisiologi akar sorgum (Sorghum bicolor L. Moench) terhadap cekaman aluminium dan defisiensi fosfor di dalam rhizotron. Jurnal Agronomi Indonesia. 38(2): 88-94.

Alnopri. 2004. Variabilitas genetik dan heritabilitas karakter-karakter pertumbuhan bibit tujuh genotipe kopi robusta-arabika. Jurnal ilmu Pertanian Indonesia. 6: 91-96.

Arunkumar B, Biradar BD, Salimath PM. 2004. Genetic variability and character association studies in rabi sorghum. Karnataka Journal Agriculture Science. 17(3): 471-475.

Arshad M, Ilyas KM, Ayub KM. 2007. Genetic divergence and path coefficient analysis for seed yield traits in Sun Flower (Helianthus annuus L.) hybrids. Pakistan Journal Botani. 39(6): 2009-2015.

Baihaki A. 2000. Teknik Rancang Dan Analisis Penelitian Pemuliaan. Diktat Kuliah (ID): Fakultas Pertanian Universitas Padjadjaran.

[Balitsereal] Balai Penelitian Tanaman Serealia. 2014. Database Sorgum danGandum. [internet]. [diunduh 6 November 2014]. Tersedia pada http://balitsereal.litbang.deptan.go.id/ind/index.php?option=com_contd anview $=$ categorydanid $=47$ :databasegandumdansorgumdanItemid $=93 \mathrm{da}$ nlayout.

[Balitsereal] Balai Penelitian Tanaman Sereal. 2011. Deskripsi varietas Numbu. Database Varietas Sorgum [Internet]. [diunduh 23 Oktober 2014]. Maros.Tersediapada:http://balitsereal.litbang.deptan.go.id/ind/index.php ?option=com_content\&view=article \&id=117: numbusorgum \&catid=47: database gand um-dan-sorgum.

Bari A. 1988. Pengujian sebaran frekuensi hasil padi dan dalam tumpang sari padi dengan jagung dan ubi kayu. Comm. Ag. 4(1): 41-45.

[BATAN] Badan tenaga nuklir nasional. 2014. Deskripsi Varietas Unggul Hasil Pemuliaan Mutasi. Jakarta (ID): PDK-Batan.

Bawazir AAA. 2009. Genetic analysis for yield and yield components in grain sorghum (Sorghum bicolor L. Moench). Jordan Journal of Agriculture. Science. 5(3): 273-281.

Beti YA, Ispandi A, Sudaryono. 1990. Sorgum. Monograf Balittan Malang No. 5. Malang (ID): Balai Penelitian Tanaman Pangan.

Biba MA. 2011.Sorghum development prospects for food and energy security. Journal Food Crop Science. 6(2): 257-269.

[BMKG] Badan Meteorologi Klimatologi dan Geofisika. 2014. Data Iklim. Bogor (ID): BMKG.

Bustamam T. 2004. Pengaruh posisi daun jagung pada batang terhadap pengisian dan mutu benih. Jurnal Stigma. 2(12): 205-208.

Chahal GS, Gosal SS. 2003. Principle and Procedures of Plant Breeding. Kolkata (IN): Narosa Publishing House.

Chavan SK, Mahajan RC, Fatak SU. 2010. Genetic variability studies in sorghum. Karnataka Journal Agriculture Science. 23(2): 322-323. 
Dermawan R. 2011. Respon Galur Sorgum terhadap Pemupukan P pada Berbagai Taraf Kejenuhan Aluminium di Tanah Masam. [Tesis]. Bogor (ID): Program Pasca Sarjana. Institut Pertanian Bogor.

Dicko MH, Gruppen H, Traore AS, Voragen AGJ, Van Berkel WJH. 2006. Sorghum grain as hoeman food in Africa, relevance of content of starch and amylase activities. African Journal.of Biotechnology.5(5): 384-395.

Din AT, Eatemad HM, Ali EA. 2012. Path coefficient and correlation assessment of yield and yield associated traits in sorghum (Sorghum bicolor L.) genotypes. American-Eurasian Jounal Agriculture and Environtment Science. 12(6): 815-819.

[Ditjen Tanaman Pangan] Direktorat Jenderal Tanaman Pangan. 2013. Kebijakan Direktorat Jenderal Tanaman Pangan dalam Pengembangan Komoditas Jagung dan Sorgum. Jakarta (ID): Kementrian Pertanian Republik Indonesia.

Efendi R, Aqil M, Pabendon M. 2013. Evaluasi genotipe sorgum manis (Sorghum bicolor (L.) Moench) produksi Biomas dan daya Ratun Tinggi. Jurnal Penelitian Pertanian Tanaman Pangan. 32(2): 186-190.

Elangovan M, Reddy GC, Bapu PK, Rani MJ. 2014. Premilinary evaluation of mini-core collection of sorghum for utilization. [Internet]. [diunduh 2015 juli 8]. Tersedia pada : http://www.researchgate.net/publication 1259893199.

Falconer DS, Mackay TDC. 1996. Introduction to Quantitative Genetics. London (GB): Longman Group Ltd.

[FAO] Food Agricultural Organanization. 2001. Dataset: Crop Water Management-Maize. Land and Water Development Division [Internet]. [diunduh pada 12 Desember 2015]. Tersedia pada http://www.fao.org.

[FAOSTAT] Food and Agriculture Organization Statistics. 2013. Sorghum Corp Production Database: Food and Agricultural Organization of the United Nations[internet].[diunduh29Januari2014].Tersediapadahttp://faostat3.f ao.org/faostat-gateway/go/to/browse/Q/*/E.

Federer WT, Nguyen NK. 2002. Incomplete block design. Encyclopedia of Environmetric. 2(1): 1039-1042.

Fehr WR. 1987. Principles of Cultivar Development, Theory and Techniques. London (GB): Macmillan Publishing.

Gaspersz P. 1992. Teknik Analisis Dalam Perancangan Percobaan. Bandung (ID): Transito.

Gill JS, RK Gumber MM, Verma, Rathore P. 2000. Genetic estimates of advanced mungbean lines derived through different selection methods. Crop Improvement Society. 27(1): 88-98.

Gomez KA, Gomez AA. 2007. Prosedur Statistik untuk Penelitian Pertanian. Jakarta (ID): UI Press.

Griffiths AJF, Wessler SR, Lewontin RC, Gelbart WM, Suzuki DT, Miller JH. 2005. Introduction to Genetic Analysis. New York (US): WH Freeman.

Haq UW, Malik MF, Rashid M, Munir M, Akram Z. 2008. Evaluation and estimation of heritability and genetic advancement for yield related attributes in wheat lines. Pakistan Journal Botany. 40(4): 1699-1702.

Hoeman S. 2012. Prospek dan Potensi Sorgum Sebagai Bahan Baku Bioetanol. Jakarta Selatan(ID): Badan Tenaga Nuklir Nasional. 
Hoeman S, Andreani S, Sihono, Indriatama WM. 2011. Stability test for Sorghum mutant lines derived from induced mutation with gamma-ray irradiation. Jurnal Atom Indonesia. 37(3): 102-106.

Hoeman S. 2008. Prospek dan potensi sorgum sebagai bahan baku bioetanol.[Internet]http://energi.bsl-online.com/archive/1.html.[diunduh 03Desember 2014]

Hoeman S. 2007. Peluang dan Potensi Pengembangan Sorgum Manis. Jakarta (ID): Dirjen Perkebunan Departemen Pertanian.

House LR. 1985. A Guide to Sorghum. Patancheru (IN): International Crops Research Institute for the Semi-Arid Tropics.

Ibrahim HM. 2015. Effectiveness of breeding methods for production of superior genotypes and maintenance of genetic variance in faba bean (Vicia faba, L.). American J ournal of Life Science. 3(1): 11-16.

[ICRISAT] International Crops Research Institute for the Semi-Arid Tropics. 1993. Descriptors for Sorghum [Sorghum bicolor (L.) Moench]. Tropics, Patancheru (IN): International Crops Research Institute for the Semi-Arid.

Ismail IG, Kodir A. 1977. Cara Bercocok Tanam Sorghum. Buletin Teknik. Lembaga Pusat Penelitan Pertanian Bogor (ID): Bogor.

Isnaini. 2010. Studi pewarisan sifat toleransi alumanium tanaman sorgum manis (Sorghum bicolor (L.) Moench). [Tesis]. Bogor (ID): Program Pasca Sarjana. Institut Pertanian Bogor.

Jain SK, Patel PR. 2014. Characters association and path analysis insorghum (Sorghum bicolor (L.) Moench) F1 and their parents. Annals of Plant and Soil Research. 16(2): 107-110.

Jambormias E, Sutjahjo SH, Jusuf M, Suharsono. 2011.Using information from relatives and path analysis toselect for yield and seed size in soybean. Sabrao Journal Breeding Genetic. 43: 44-58.

Jambormias E, Sutjahjo SH, Jusuf M, Suharsono. 2004. Keragaan, keragaman genetic dan heritabilitas 11 karakter kuantitatif kedelai (Glycine max L. Merrill) pada generasi seleksi F5 persilangan varietas Slamet $\mathrm{x}$ Nakhonsawan. Jurnal Pertanian Kepulauan. 3(2): 115-124.

Jayaramachandran M, Kumaravadivel N, Eapen S, Kandasamy G. 2010. Gene action for yield attributing characters in segregating generation (M2) of sorghum (Sorghum bicolor L.). Electronic Journal of Plant Breeding. 1(4): 802-805

Kamatar MY, Biradar BD, Sowmya HH, Brunda SM, Deepakkumar GS, Sanjeevsingh R, Ramaling H. 2015. Genetic variability and selection for grain mold resistance in F3 progenies of sorghum. International Journal of Farming and Allied Scis. 4(4): 334-340.

Kanbar A, Kondo K, Shashidhar HE. 2011. Comparative efficiency of pedigree, modified bulk and single seed descent breeding methods of selection for developing high yielding lines in rice (oryza sativa L.) under aerobic condition. Electronic Journal of Plant Breeding. 2(2): 184-193.

Kelley TG, Rao PP, Singh RP. 1992. Trend in Sorghum production and utilization. Progress Report 108. Resource Management Program Economic Group. Patancheru (IN): International Crops Research Institute for the Semi-Arid. 
Kenga R, Tenkouano A, Gupta SC, Alabi SO. 2006. Genetic and phenotypic association between yield components in hybrid sorghum populations. Euphytica. 150: 319-326.

Knight R. 1979. Practical in Statistic and Quantitative Genetic. Australia (AU): Australian Vice Chancelors Commite.

Komariah, Hermiati N, Baihaki A. 1992. Evaluasi evektivitas metode seleksi pedigree dan metode SSD pada kedelai generasi F4. Zuriat. 3(2): 46-51.

Kong W, Jin H, Franks CD, Kim C, Bandhopadhyay R, Rana MK, Auckland AS, Valorie H, Rainvile K, Burow GB, Woodfin C, Burke JJ, Peterson AH .2013. Genetic analysis of recombinant inbred lines for sorghum bicolor $\mathrm{x}$ sorghum propinquum. Journal Genes Genomes and Genetics. 3: 101-108.

Koumber RM, El-Gammaal AA. 2012. Inheritance and gene action for yield and its attributes in three bread wheat crosses (Triticum aestivum L.). World Journal of Agriclture Science. 8(2): 156-162.

Kuswanto. 2006. Keragaman genetik populasi bulk F2, F3, dan F4 Kacang panjang (Vigna sesquipedalis (L) Fruwirth) hasil persilangan PS $\mathrm{x}$ MLG 15151. Agrivita. 28(2): 109-114.

Lalic A, Kovacevic J, Novoselovic D, Dresner G, Babic D. 2003. Comparison of pedigree and single seed descend method SSD in early generation of barley. Brazilian Plant Breed. 1: 1-6.

Larik AS, Memon S, Soomro ZA. 2009. Radiation induced polygenis mutations in Sorghum bicolor L. Journal Agriculture Research. 47(1): 11-19.

Mallinath V, Biradar BD, Chitapur BM, Salimath PM, Yenagi N, Patil SS. 2004. Variability and correlation studies in populationsorghum. Karnataka Journal Agriculture Science.17(3): 463-467.

Mangoendidjojo W. 2003. Dasar-Dasar Pemuliaan Tanaman. Yogyakarta (ID): Kanisius.

Mardiana Y . 2015. Seleksi galur-galur gandum (Triticum aestivum L.) hasil persilangan OASIS xHP1744 pada dua agroekosistem. [Tesis]. Bogor (ID): Program Pasca Sarjana. Institut Pertanian Bogor.

Martin JH. 1970. History and Classification of Sorgum. Connecticut (US): The Avi Publishing.

Matchik A, Sumertajaya IM. 2006. Perancangan Percobaan dengan Aplikasi SAS dan Minitab Jilid 2. Bogor (ID): IPB Press.

Miftahorrachman. 2005. Sidik lintas karakter vegetatif dan generatif plasma nutfah pinang (Areca catechu L.) aksesi Sumut-2. Buletin Palma. 29: 47-53.

Miladinović J, Burton JW, Tubić SB, Miladinović D, Djordjević V, Djukić V. 2011. Soybean breeding: comparison of the efficiency of different selection methods. Turk Journal for Agriculture. 35: 469-480.

Munier JNG, Ney B. 1998. Seed growth rate in grain legumes. II. Seed growth rate depends on cotyledon cell number. J. exp. Bot. 49(329):1971-1976.

Mustafavi MR, Ross HZ. 1990. Defoliation effects on grain filling of R-nj color selected maize strains. Crop Science. 30: 358-36

Natawijaya A. 2012. Seleksi generasi awal segregan F2 gandum (Triticum aestivum L.) untuk perbaikan daya hasil. [Tesis]. Bogor (ID): Program Pasca Sarjana. Institut Pertanian Bogor. 
Naserian B, Asadi AA, Rahimi M, Ardakani MR. 2007. Evaluation of wheat cultivars and yield component under irrigated and rainfed condition. Australian Journal Plant Science. 6: 214-224.

Okiyo TS. Gudu O, Kiplagat, Owouche J. 2010. Combining drought and alumunium toxicity tolerance to improve sorghum productivity. African Crop Science Journal. 18(4): 147-154.

Pabendon MB, Mas'ud S, Sarungallon RS, Nur A. 2012. Penampilan fenotipik dan stabilitas sorgum manis untuk bahan baku bioetanol. Jurnal Penelitian Pertanian Tanaman Pangan. 31(1): 60-69.

Pinaria AA, Baihaki R, Setiamihardja, Daradjat AA. 1995. Variabilitas genetic dan heritabilitas karakter biomasa 53 genotipe kedelai. Zuriat. 6(2): 88-92.

Phuong N, Stutzel H, Uptmoor R. 2013. Quantitative trait loci associated to agronomic traits and yield components in a Sorghum bicolor L. Moench RIL population cultivated under pre-flowering drought and wellwatered conditions. Agricultural Sciences. 4(12): 781-791.

Poehlman JM, Sleper DA. 1996. Breeding Field Crop $4^{\text {th }}$. Iowa (US): Iowa Press.

Poespodarsono S. 1988. Dasar-dasar Ilmu Pemuliaan Tanaman. Pusat Antar Universitas (PAU) Institut Pertanian Bogor Bekerjasama dengan Lembaga Sumberdaya Informasi-IPB.

Prabowo AB, Prastowo IU, Firmansyah RH, Anasiru. 1998. Pengelolaan air untuk tanaman sorgum. Prosiding Seminar dan Lokakarya Sorgum Nasional (ID): Balai Penelitian Tanaman Serealia Maros.

Purnomohadi M. 2006. Potensi penggunaan beberapa varietas sorgum manis (Sorghum bicolor (L.) Moench) sebagai tanaman pakan. Jurnal Penelitian Hayai. 12: 41-44.

Puspitasari W, Hoeman S, Wirnas D, Trikoesoemaningtyas. 2012. Evaluating genetic variability of sorghum mutant lines tolerant to acid soil. Jurnal Atom Indonesia. 38 (2): 83-88.

Puspitasari W. 2011. Pendugaan parameter genetik dan seleksi karakter agronomi dan kualitas sorgum di lahan masam. [Tesis]. Bogor (ID): Program Pasca Sarjana. Institut Pertanian Bogor.

Rani CH, Umakanth AV. 2012. Genetic variation and trait inter-relationship in F1 hybrids of sweet sorghum. Journal of Tropical Agriculture. 50(2): 80-83.

Reddy PS, Patil JV, Nirmal SV, Gadakh SR. 2012. Improving post-rainy season sorghum productivity in medium soils.Current Science.102(6).

Reddy RP. 1996. The Effect of Long-Term Selection on Growth of Poultry. Poultry Science. 75: 1164-1167.

Riaz R, Chowdhry M. 2003. Estimation of variation and heritability of some physio-morphic traits of wheat under drought conditions. Asian Journal Plant Science. 2(10): 748-755.

Rini EP. 2014. Pendugaan nilai heterosis genotipe F1 sorgum (Sorghum bicolor (L.) Moench) hasil persilangan line $\mathrm{x}$ tester. [Skripsi]. Bogor (ID): Institut Pertanian Bogor.

Roy D. 2000. Plant Breeding Analysis and Exploitation of Variation. New Delhi (IN): Narosa Publishing House. 
Sya'diyah N, Basoeki TR, Saputra A, Firmansyah, Utomo SD. 2010. Parameter genetik dan korelasi karakter agronomi kacang panjang populasi F4 persilangan testa coklat X coklat putih. Jurnal Agrotropika.15(2):73- 7.

Safuan LO, Boer D, Wijayanto D, Susanti N. 2014.Analisis koefisien lintas berbagai sifat agronomi yang mempengaruhi hasil kultivar jagung pulut (Zea mays Ceritina Kulesh) lokal Sulawesi Tenggara. Agriplus. 24: 136-143.

Samak NRA, Hittalmani S, Shashidhar N, Biradar H. 2011. Exploratory studies on genetic variability and genetic control for protein and micronutirient contont in F4 and F5 generation of rice (Oryza sativa L.). Asian Journal of Plant Science. 10(7): 376-379.

Sami RA, Yeye MY, Usman IS, Hassan LB, Usman M. 2013a. Studies on genetic variability in some sweet sorghum (Sorghum bicolor(L Moench) genotypes. Journal Academic Research. 1(1): 1-6.

Sami RA, Yeye MY, Ishiyaku MF, Usman IS. 2013b. Heritabiliy studies in some sweet sorghum (Sorghum Bicolor. L.Moench) genotypes. Journal of Biology, Agriculture, and Healthcare. 3(17): 49-51.

Santoso J. 2007. Tindak gen ketahanan terhadap penyakit karat (Pucinnia arachidis, Speg.) pada kacang tanah. Jurnal Ilmu Pertanian Indonesia. 9(2): 172-177.

Sarwar S, Sidiq MS, Saleem M, Abbas G. 2004. Selection criteria in F3 and F4 population of mungbean. Pakistan Journal Botani. 36: 297-310.

Sihaloho AN. 2015. Analisis genetik dan efisiensi seleksi menggunakan single seed descent pada kedelai (Glycine max (L.) Merr.) untuk adaptasi tanah masam. [Disertasi]. Bogor (ID): Institut Pertanian Bogor.

Singh RK, Chaudary BD. 1979. Biometrical Methods in Quantitaive Genetics Analysis. New Delhi (IN): Kaylani Publisher.

Sirappa MP. 2003. Prospek pengembangan sorgum di Indonesia sebagai komoditas alternatif untuk pangan dan industri. Jurnal Litbang Pertanian. 22(4): 133-140.

Smith CW, Frederiksen RA. 2000. Sorghum Origin, History, Technology and Production. New York (US): John Wiley and Sons.

Sugianto, Nurbaiti, Deviona. 2015. Variabilitas genetik dan heritabilitas karakter agronomi beberapa genotipe sorgum manis (Sorghum bicolor L. Moench) koleksi Batan. Jurnal Faperta. 2(1).

Sulistyowati Y, Trikoesoemaningtyas, Sopandie D, Ardhie SW, Nugroho S. 2015. Estimation of genetic parameters and gene actions of sorghum tolerance to low p condition. International Journal of Agronomy and Agricultural Research. 7(3): 38-46.

Sumarno N, Zuraida. 2006. Hubungan korelatif dan kausatif antara komponenhasil dengan hasil kedelai. Jurnal Penelitian Tanaman Pangan.25(1): 38-44.

Sumiyati. 2011. Pewarisan Sifat Toleran Defisiensi Fosfor pada Sorgum (Sorghum bicolor (L.) Moench). [Tesis]. Bogor (ID): Program Pasca Sarjana. Institut Pertanian Bogor.

Sungkono. 2010. Seleksi galur mutan sorgum (Sorghum bicolor (L.) Moench) untuk produktivitas biji dan bioetanol tinggi di tanah masam melalui pendekatan participatory plant breeding [Disertasi]. Bogor (ID):Institut Pertanian Bogor. 
Sungkono, Trikosoemaningtyas, Wirnas D, Sopandie D, Hoeman S, Yudianto MA. 2009. Penduga paremeter genetik dan seleksi galur mutan sorgum (Sorghum bicolor (L.) Moench) di tanah masam. Buletin Agronomi Indonesia. 37(3): 220-225.

Syukur M, Sriani S, Yunianti R, Kusumah AK. 2011. Pendugaan ragam genetik dan heritabilitas karakter komponen hasil beberapa genotipe cabai. Jurnal Agrivigor. 10(2): 148-156.

Syukur M, Sujiprihati S, Yunianti R. 2012. Teknik Pemuliaan Tanaman. Jakarta (ID): Penebar Swadaya.

Taylor J, Taylor JRN. 2002. Alleviation of the adverse effects of cooking on protein digestibility in sorghum through fermentation in traditional African porridges. Journal of Food Science and Technology: 129-138.

Tjitrosoepomo G. 2000. Taksonmi Tumbuhan (Spermatophyta). Yogyakarta (ID): Gadjah Mada University Press.

Tsuchihashi N, Goto Y. 2008. Year round cultivation of sweet sorghum [Sorghum bicolor (L.) Moench] through a combination of seed and ratoon cropping in Indonesia savanna. Plant Prod Science. 11(3): 377-384.

Wardani S . 2014. Identifikasi segregan transgresif gandum (Triticum aestivum L.) toleran suhu tinggi dan berdaya hasil tinggi di lingkungan tropika. [Tesis]. Bogor (ID): Program Pasca Sarjana. Institut Pertanian Bogor.

Wardina E, Pranowo D. 2011. Pendugaan parameter genetik, korelasi, dan klasterisasi 20 genotipe jarak pagar (Jatropha curcas L.). Buletin Plasma Nutfah. 17(1): 46-53.

Welsh JR. 2005. Fundamentals of Plant Gnenetics and Breeding. New York (US): John Wiley and Sons.

Wirnas D, Widodo I, Sobir, Trikoesoemaningtyas, Sopandi D. 2006. Pemilihan karakter agronomi untuk menyusun indeks seleksi pada 11 populasi kedelai generasi F6. Buletin Agronomi. 34: 19-24.

Yamin M. 2014. Pendugaan komponen ragam karakter agronomi gandum (Triticum aestivum L.) toleran suhu tinggi dan identifikasi marka Simple Sequence Repeat (SSR) terpaut suhu tinggi. [Tesis]. Bogor (ID): Program Pasca Sarjana. Institut Pertanian Bogor.

Yazdani M. 2012. Correlation and path analysis studies on main agronomic characters withits yield of sorghum bicolor. International journal of Agronomy and Plant Production. 3(12): 645-650.

Zecevic V, Boskovic J, Dimitrijevic M, Petrovic S. 2010. Genetic and phenotypic variability of yield components in wheat (Triticum aestivum L.). Journal Agriculture Science. 16(4): 422-42.

Zongjian Y, Van Oosterom EJ, Jordan DR, Doherty, Hammer GL. 2010. Genetic variation in potential kernel size affect growth and yield of Sorghum. Crop Science. 50: 685-695. 

LAMPIRAN 



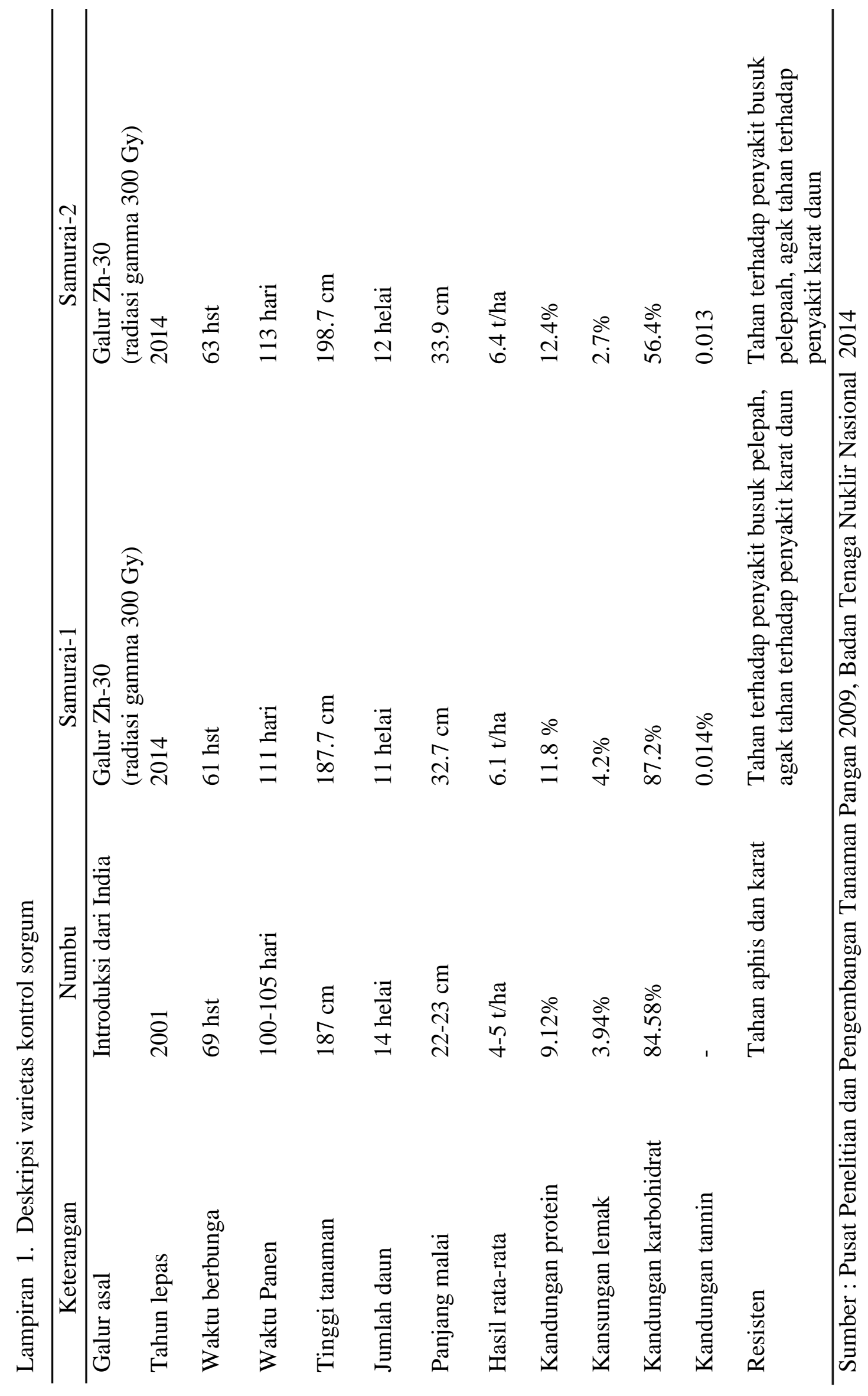


Lampiran 2. Rata-rata curah hujan dan temperatur selama penelitian di Dramaga

\begin{tabular}{lcc}
\hline Bulan & Curah hujan $(\mathrm{mm})$ & Temperatur $\left({ }^{0} \mathrm{C}\right)$ \\
\hline Februari 2014 & 337.0 & 25.0 \\
Maret 2014 & 300.0 & 25.6 \\
April 2014 & 450.0 & 26.2 \\
Mei 2014 & 300.0 & 26.2 \\
Kisaran & $300-450$ & $25.0-26.2$ \\
\hline Bulan & & Temperatur $\left({ }^{0} \mathrm{C}\right)$ \\
\hline Juli 2014 & 349.0 & 26.9 \\
Agustus 2014 & 50.0 & 29.0 \\
September 2014 & 22.0 & 29.0 \\
Oktober 2014 & 180.0 & 28.2 \\
Kisaran & $22-349$ & $26.9-29.0$ \\
\hline
\end{tabular}

Sumber : Badan Meteorologi dan Geofisika 2014 
Lampiran 3. Algoritma eksplorasi kecenderungan sebaran sifat-sifat kuantitatif kaitannya dengan aksi gen aditif, dominan serta epistasis komplementer dan duplikat (Jayaramachandran et al.2010)

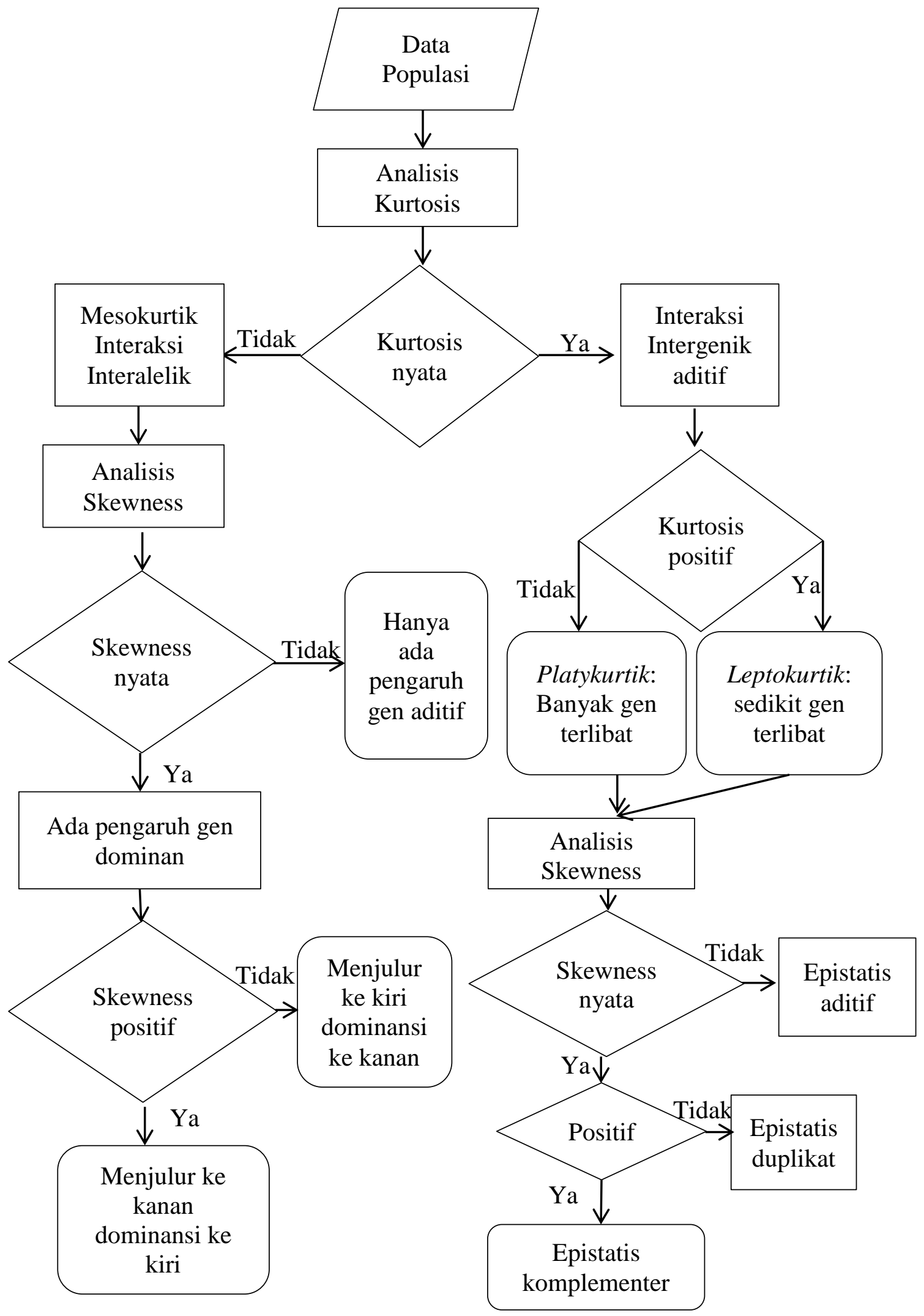




\section{DAFTAR RIWAYAT HIDUP}

Penulis lahir di Padang pada tanggal 18 April 1990, merupakan anak pertama dari dua bersaudara dari pasangan ayah Jon Adri dan Ibu Ermawati Arief. Penulis menyelesaikan pendidikan di SD Negeri 05, SMP Negeri 13, dan SMA Negeri 2 Padang, Sumatera Barat. Penulis diterima di Universitas Negeri Andalas melalui jalur Seleksi Nasional Masuk Perguruan Tinggi Negeri (SNMPTN) pada Fakultas Pertanian, jurusan Agroekotekhnologi, bidang kajian ilmu Pemuliaan Tanaman dan memperoleh gelar Sarjana Pertanian (SP). Selama menjadi mahasiswa penulis menjadi asisten pratikum mata kuliah Dasar-Dasar Pemuliaan Tanaman, Dasar-Dasar Agronomi dan Tekhnologi Produksi Tanaman Pangan. Penulis melanjutkan studi ke Program Pascasarjana IPB, pada program studi Pemuliaan dan Bioteknologi Tanaman (PBT) pada tahun 2013-2016. Biaya perkuliahan ditanggung oleh beasiswa pendidikan pascasarjana dalam negeri (BPPDN) tahun 2013-2016. Artikel yang berjudul "Pendugaan Nilai Parameter Genetik dan Seleksi RILs F5 Sorgum Hasil Penggaluran dengan Metode single seed descent" telah diterbitkan pada International Journal of Agronomy and Agricultural Research (IJAAR) Vol. 8(2): 95-103. 